\title{
The effect of temperature on the development and reproduction of Busseola fusca (Lepidoptera: Noctuidae)
}

\section{J Glatz}

\section{3}

Dissertation submitted in fulfilment of the requirements for the degree Magister Scientiae in Environmental Sciences at the Potchefstroom Campus of the North-West University

Supervisor: $\quad$ Prof MJ du Plessis

Co-supervisor: $\quad$ Prof $\mathrm{J}$ van den Berg

May 2015 


\section{ACKNOWLEDGEMENTS}

I am very grateful to my study leader, Prof. Hannalene du Plessis, for her enthusiasm, encouragement and support. Furthermore, I would like to thank her for helping me with the statistical analyses. Her assistance and guidance helped a lot towards the success of this dissertation.

I want to thank my co-supervisor, Prof Johnnie van den Berg, for his advice and support as well as his assistance in finishing this dissertation.

I want to thank my mom and dad, Marianna and Uli, for their love, encouragement, patience and financial support to make a success of this dissertation. And also my sister, Yolandi, for her love and support.

I also want to thank my friends and colleges who have been with me while working in the laboratory and field as well as to finish my dissertation. 


\section{ABSTRACT}

Busseola fusca is an indigenous lepidopteran pest species in tropical Africa, attacking several grain crops. Crop loss caused by this pest can be as high as $100 \%$ depending on conditions. Despite it being a major pest in Africa, occurring in contrasting climatic zones, only a few studies have been published on its developmental biology. The effect of temperature on the development of $B$. fusca was studied at five different temperature regimes namely 15, 18, 20, 26 and $30 \pm 1$ ${ }^{\circ} \mathrm{C}$ and $70 \pm 30 \%$ relative humidity $(\mathrm{RH})$ with $14 \mathrm{~L}$ : 10D photoperiod. The number of instars for $B$. fusca was also determined. The most favourable temperature as well as the upper threshold temperature for larval development was found to be between 26 and $30{ }^{\circ} \mathrm{C}$. Total development period was 152.6 to 52.6 days, respectively, at 15 ${ }^{\circ} \mathrm{C}$, and $26-30{ }^{\circ} \mathrm{C}$. The thermal constants for $B$. fusca was 99.50, 536.48, 246.25 and $893.66^{\circ} \mathrm{D}$ and lower temperature threshold was $10.36,8.14,8.99$ and $8.84{ }^{\circ} \mathrm{C}$, for completion of the egg, larval, pupal, and egg-to-adult stages, respectively. The number of larval instars was determined by using head capsule widths that ranged from 0.31 - $2.68 \mathrm{~mm}$. Clear distinctions of head capsule widths could be made from instar 1 to 3 , yet overlapping occurred from instar 4 to 6 . No distinction could be made between instars 7 and 8 in terms of head capsule width. All successive instars, except for instar eight, increased in size according to Dyar's ratio. The effect of temperature on reproduction of $B$. fusca was studied at $15,20,26$ and $30 \pm 1{ }^{\circ} \mathrm{C}, 70$ $\pm 30 \% \mathrm{RH}$ with 14L: 10D photoperiod. Oviposition occurred at all the temperatures evaluated, but no fertility was recorded at $30^{\circ} \mathrm{C}$. The total number of eggs laid by $B$. fusca females was 300 - 400 eggs and the optimum temperature for oviposition and fertility was determined to be between 20 and $26{ }^{\circ} \mathrm{C}$. Results from this study on the thermal constants and lower and upper threshold temperatures of $B$. fusca can be used to predict the impact of climate change on the distribution and population growth of this pest.

Key words: Busseola fusca, degree-days, development, fertility, instars, reproduction, temperature 


\section{OPSOMMING}

\section{Titel: Die effek van temperatuur op die ontwikkeling en voortplanting van}

\section{Busseola fusca (Lepidoptera: Noctuidae)}

Busseola fusca is ' $n$ inheemse plaag op verskeie graangewasse in tropiese Afrika. Hierdie plaag is van ekonomiese belang en kan tot $100 \%$ gewasverlies veroorsaak, afhangende van die toestande. Alhoewel B. fusca 'n ernstige plaag in Afrika is en in teenstellende klimaatsones voorkom, is slegs ' $n$ paar studies oor die insek se ontwikkelingsbiologie gepubliseer. Die effek van temperatuur op die ontwikkeling van $B$. fusca was by vyf verskillende temperature bestudeer, naamlik 15, 18, 20, 26 en 30 $\pm 1{ }^{\circ} \mathrm{C}$ en $70 \pm 10 \%$ relatiewe humiditeit $(\mathrm{RH})$ met ' $\mathrm{n} 14 \mathrm{~L}: 10 \mathrm{D}$ fotoperiode. Die aantal instars was ook bepaal. Die mees geskikte - en hoogste drempeltemperatuur was tussen 26 en $30^{\circ} \mathrm{C}$. Volledige ontwikkeling het van 152.6 dae by $15^{\circ} \mathrm{C}$ tot 52.6 dae by $26-30{ }^{\circ} \mathrm{C}$ verminder. Die termiese konstante vir ontwikkeling van $B$. fusca eiers, larwes, papies en die eier-tot-volwasse stadium was 99.50, 536.48, 246.25 en $893.66{ }^{\circ} \mathrm{D}$ en laagste drempeltemperatuur was $10.36,8.14,8.99$ en $8.84{ }^{\circ} \mathrm{C}$, onderskeidelik. Die wydte van kopkapsules was gemeet om die instars te bepaal en het gewissel van $0.31-2.68 \mathrm{~mm}$. Daar was duidelike verskille tussen die eerste drie instars se kopkapsule-wydtes, maar oorvleueling het van die vierde instar af voorgekom. Daar was geen onderskeiding tussen die sewende en agtste instar se kopkapsule-wydtes nie. Al die opeenvolgende instars, behalwe instar agt, se kopkapsules het vergroot volgens Dyar se verhouding. Die effek van temperatuur op voortplanting van $B$. fusca was by $15,20,26$ en $30 \pm 1{ }^{\circ} \mathrm{C}$ en $70 \pm 30 \% \mathrm{RH}$ met ' $\mathrm{n}$ 14L: 10D fotoperiode bestudeer. Eierlegging het by al die temperature plaasgevind, maar al die eiers wat by $30^{\circ} \mathrm{C}$ gelê was, was onvrugbaar. Die totale aantal eiers wat deur B. fusca wyfies gelê was, het tussen 300 en 400 eiers gewissel. Die mees geskikte temperatuur vir eierlegging en vrugbaarheid van $B$. fusca wyfies was tussen 20 en $26{ }^{\circ} \mathrm{C}$. Resultate van die studie met betrekking tot die termiese konstantes asook hoogste en laagste drempeltemperature van $B$. fusca kan gebruik word om die impak van klimaatsverandering op die verspeiding en populasietoename van hierdie plaag te bepaal.

Sleutelwoorde: Busseola fusca, graad-dae, instars, ontwikkelling, temperatuur, voortplanting, vrugbaarheid 


\section{TABLE OF CONTENTS}

ACKNOWLEDGEMENTS

ABSTRACT

OPSOMMING iii

TABLE OF CONTENTS ....................................................................................... iv

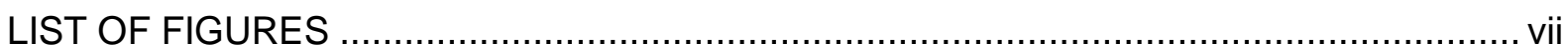

LIST OF TABLES .................................................................................................... viii

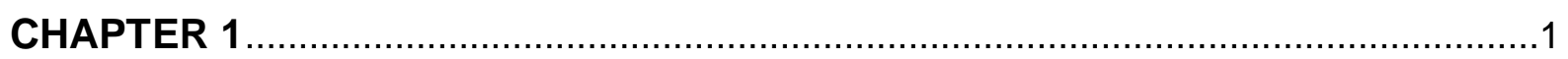

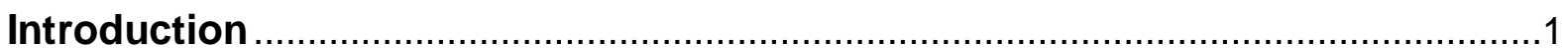

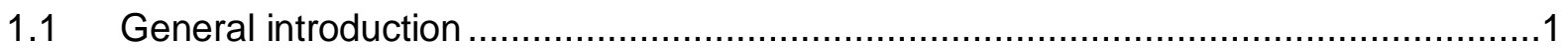

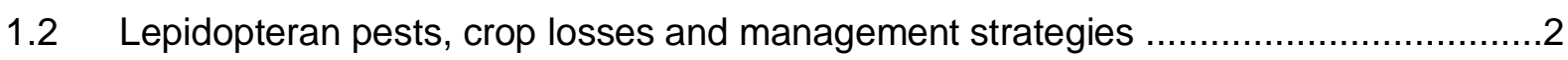

1.2.1 Lepidopteran pests of grain crops in Africa ...............................................

1.2.2 Stem borer pests of maize and sorghum in southern Africa...............................4

1.3 Busseola fusca as a pest of maize in Africa......................................................... 4

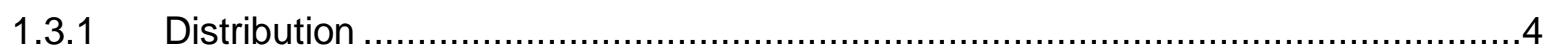

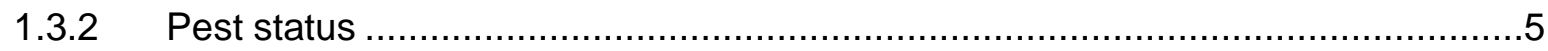

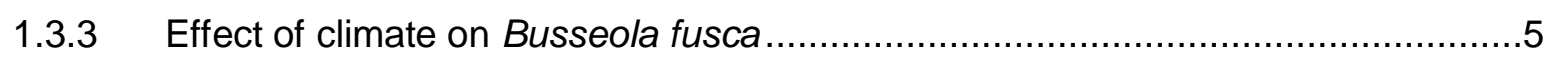

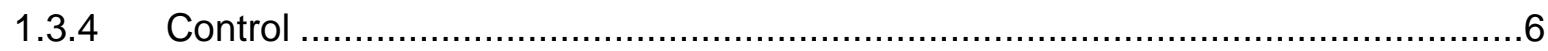

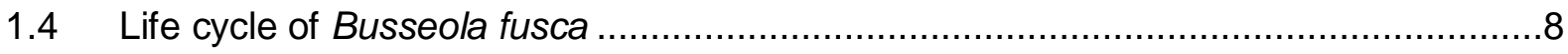

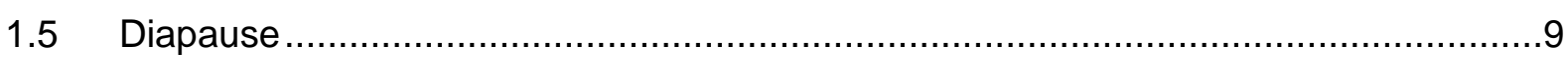

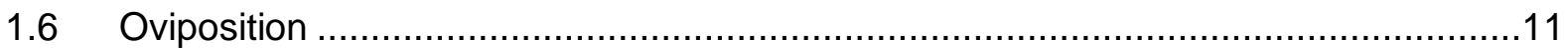

$1.7 \quad$ Temperature dependent development and reproduction ....................................11

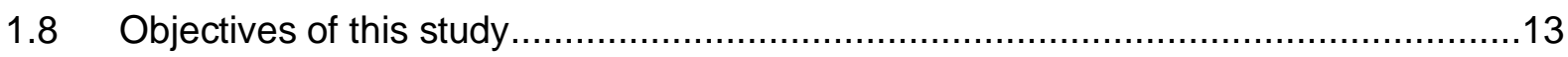

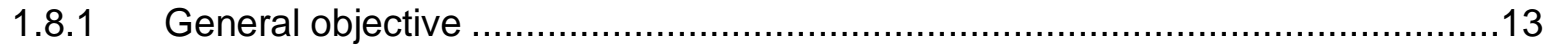

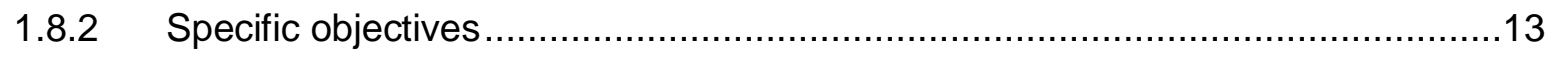

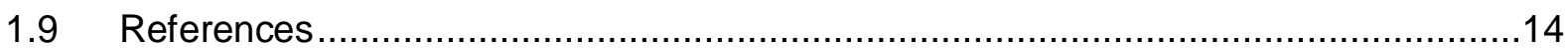


The effect of temperature on the development of Busseola fusca (Lepidoptera:

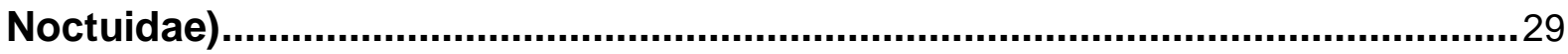

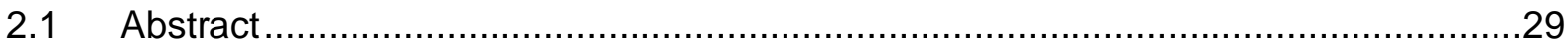

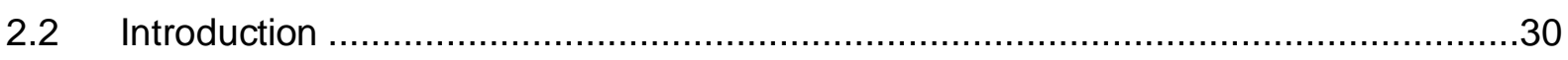

2.2.1 The effect of temperature on insect development .........................................30

2.2.2 Larval development of Busseola fusca (life cycle) ........................................30

2.2.3 Geographical distribution of Busseola fusca .....................................................

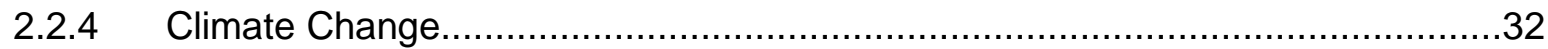

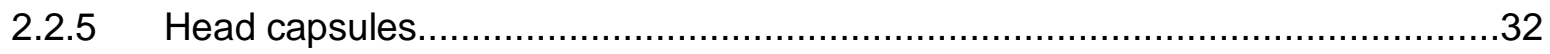

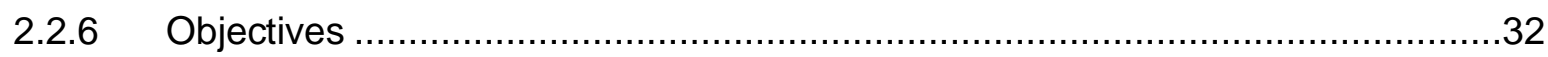

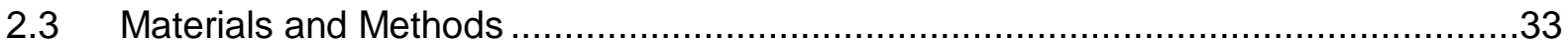

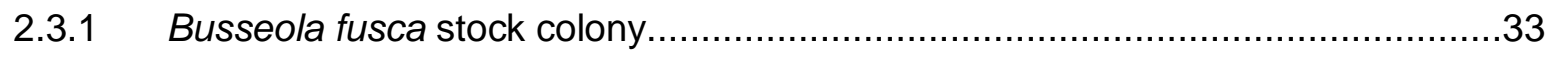

2.3.2 Temperature-dependent egg development............................................33

2.3.3 Temperature-dependent larval and pupal development..................................34

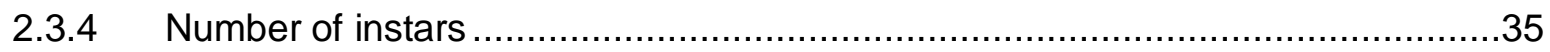

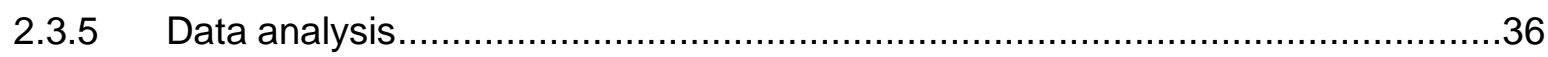

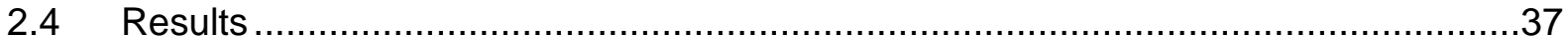

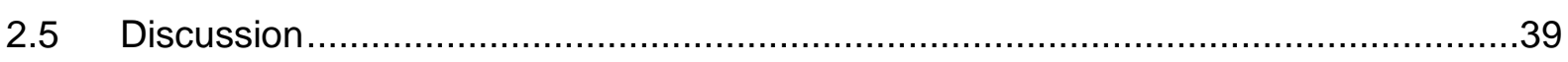

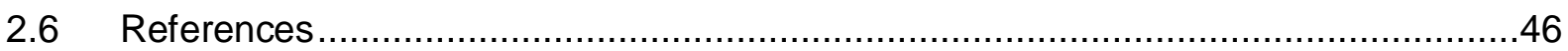

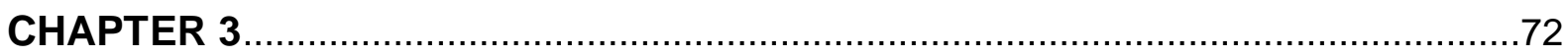

The effect of temperature on reproduction of Busseola fusca (Lepidoptera:

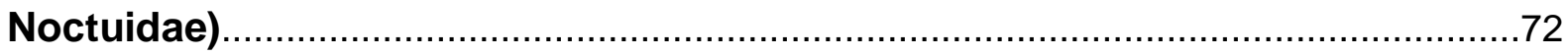

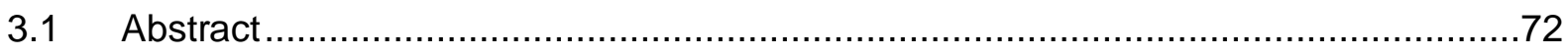

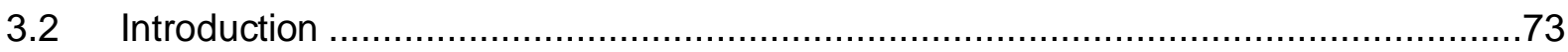

3.2.1 The effect of temperature on reproduction ...............................................73

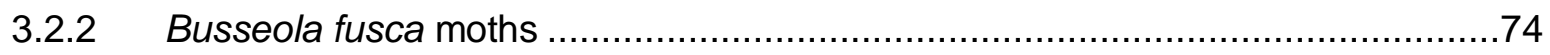

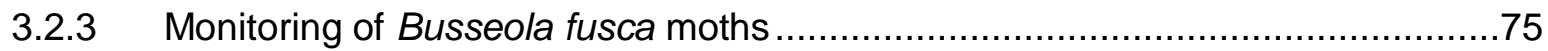




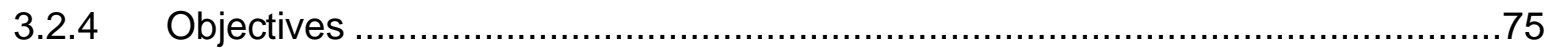

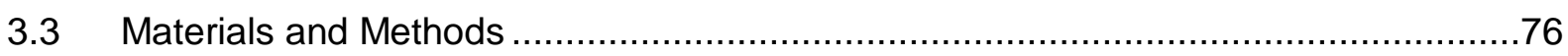

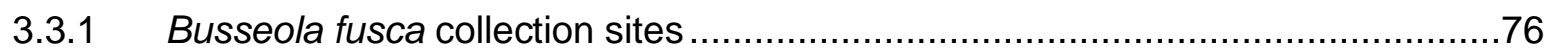

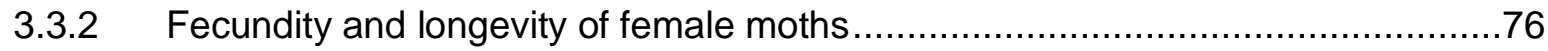

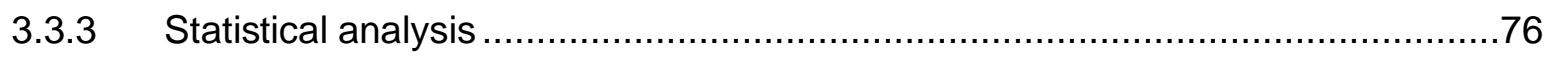

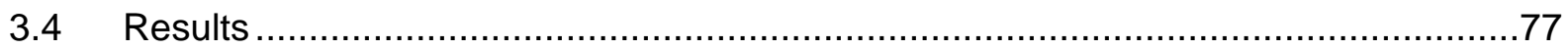

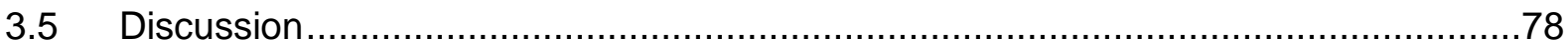

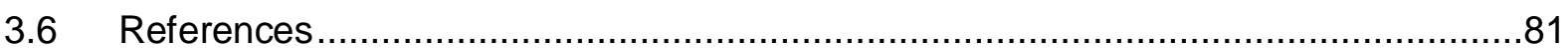

CHAPTER 4

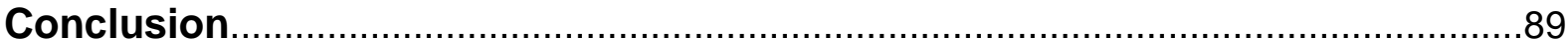

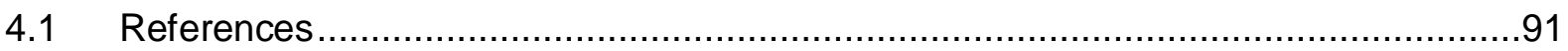




\section{LIST OF FIGURES}

Figure 1.1: $\quad$ Life cycle of Busseola fusca.

Figure 1.2: The male (top) and female (bottom) pupae of Busseola fusca distinguished by the genital scars on sternum 9 of males and sternum 8 of females.

Figure 2.1: Containers used for rearing of Busseola fusca: a) oviposition chambers with one cut maize stem per moth pair; b) desiccator with small plastic containers for egg development; c) test tubes used for larval development; d) plastic container with water and test tubes containing pupae.

Figure 2.2: $\quad$ Temperature and $\mathrm{RH}$ recorded inside a maize stem with an iButton ${ }^{\circledR}$..........59

Figure 2.3: Busseola fusca larvae where fed with compact unfolded leaves from the second to the fifth instar (above) and a piece of maize stem from the six instar onwards (bottom).

Figure 2.4: Damage by Busseola fusca larvae through tunnelling into maize stems......61

Figure 2.5: Piece of maize plant cut longitudinally and kept together with an elastic band for daily observation of $B$. fusca larvae.

Figure 2.6: The relationship between Busseola fusca development rates and rearing temperature for larval instar one to six.

Figure 2.7: The relationship between development rates and rearing temperature for eggs, larvae, pupae and egg-to-adult stages of Busseola fusca.

(Development rates for larvae and egg-to-adult stage include instars 7 and 8).

Figure 2.8: Frequency distribution of head capsule widths of Busseola fusca larvae.

Each coloured line indicates the range of a specific instar. 65

Figure 2.9: Relationship between head capsule width and instar of Busseola fusca larvae. The linear regression shows a straight line which fitted Dyar's rule. 66

Figure 2.10: Head capsules of Busseola fusca larvae indicating instars one to seven.....67 


\section{LIST OF TABLES}

Table 1.1: Important lepidopteran pests of grain crops in Africa

Table 2.1: Mean development time (days \pm S.E.) of different life stages and larval survival of Busseola fusca at constant temperatures. The range of days to develop is shown in brackets

Table 2.2: $\quad$ Linear regression equations describing the relationship between development rate $(1 /$ days $)$ and temperature $\left(15-26^{\circ} \mathrm{C}\right)$ and the thermal requirements of different developmental stages of Busseola fusca.

Table 2.3: Mean development time in days and degree-days $\left({ }^{\circ} \mathrm{D}\right)$ for Busseola fusca at constant temperatures from $15-26^{\circ} \mathrm{C}$. Degree-days were calculated using the lower threshold temperature for development determined for each developmental stage $\left(\right.$ eggs $=10.36{ }^{\circ} \mathrm{C}$, larvae $=8.99^{\circ} \mathrm{C}$, pupae $=8.14{ }^{\circ} \mathrm{C}$ and egg-to-adult $=8.84^{\circ} \mathrm{C}$ )

Table 2.4: Mean head capsule widths and ranges for each Busseola fusca larval instar stage and Dyar's ratio.

Table 3.1: Mean fecundity and longevity ( \pm S.E.) of Busseola fusca moths at constant temperatures.

Table 3.2: Fertility ( \pm S.E.) of Busseola fusca eggs at constant temperatures. 88 


\section{CHAPTER 1}

\section{Introduction}

\subsection{General introduction}

The most important cereal crops in Africa are maize, millet, rice and sorghum. Since the $16^{\text {th }}$ century, maize (Zea mays L.) has been used in Africa and by the $17^{\text {th }}$ century it was cultivated widely in Africa (Polaszek \& Khan, 1998).

Climate change is a worldwide phenomenon that affects agricultural productivity. This may result in a decrease in crop production and an increase in food costs and food insecurity. However, climate change impacts vary among regions and may have either positive or negative effects, depending on how the impact affects agricultural productivity (Calzadilla et al., 2014). Climate change affects crop production through five main factors: temperature, precipitation, elevated carbon dioxide levels, varying environments and water availability (IPCC, 2007; World Bank, 2007). Crop production is mostly dependent on temperature and soil moisture availability. Temperature largely determines the length of the growing season and development rate of crops. In certain areas, higher temperatures will lead to a decrease in the number of frost-days thereby creating climates more conducible for crop production. However, in arid and semi-arid regions, higher temperatures will result in shorter cropping cycles and reduction in crop production due to reduced water availability (IPCC, 2007).

South Africa is largely a semi-arid country, with agro-ecological zones that ranges from desert and semi-desert areas in the north-western region, to sub-humid and wet areas in the eastern coastal region (Calzadilla et al., 2014). The average rainfall in South Africa is 464 $\mathrm{mm}$ per year, compared to a world average of $857 \mathrm{~mm}$ per year (United Nations, 2009). Prediction models show that South Africa will have a much drier climate in future with a small increase in temperature, leading to a decrease in the total production of crops (Calzadilla et al., 2014). Various adaptive methods have been integrated to alleviate climate change in South Africa such as development of irrigation systems and improvements in agricultural productivity (Hussain \& Hanjra, 2004; Molden et al., 2007; FAO, 2008; Calzadilla et al., 2013). The methods mentioned above have been discussed by Calzadilla et al. (2013). Irrigation is practiced throughout South Africa and accounts for $62 \%$ of the water used in the country (DWAF, 2004). It can therefore be said that agriculture will be highly affected by 
climate change. Farmers practicing rainfed agriculture have already been affected by climate change (FAO, 2011).

Future crop production patterns will depend on the severity of climate change which, for example, may cause longer or shorter growing seasons (Adams et al., 1990; Matthews et al., 1997; Aggarwal \& Mall, 2002; Xiong et al., 2008). Methods such as changing planting and harvest dates (Winters et al., 1998; Susanna et al., 2007; Lobell et al., 2008) and introducing new crop cultivars with longer growing seasons (Jørgen \& Marco, 2002; Ogden \& Innes, 2008) have been used in order to adapt to global changes (Li et al., 2014). Due to these adaptive methods, crop phenology may be influenced which may lead to longer growing seasons (Zhang et al., 2013).

Crop phenology changes as temperature varies over time and space (Chmielewski et al., 2004; Hu et al., 2005; Tao et al., 2006; Sacks \& Kucharik, 2011; Siebert \& Ewert, 2012). The growth and development of maize is mainly affected by temperature, radiation, photoperiod and water. These factors may vary in time and space. Different planting dates therefore result in crops experiencing different environmental conditions (Tsimba et al., 2013), which may also influence stem borer - host plant interactions.

\subsection{Lepidopteran pests, crop losses and management strategies}

\subsubsection{Lepidopteran pests of grain crops in Africa}

Maes (1997) reported 20 economically important stem borer species in Africa. These species vary in distribution, relative abundance and pest status (Megenasa, 1982; Songa et al., 1998; Ndemah et al., 2001). The most important lepidopteran pests of grain crops in Africa are listed in table 1.1.

A high diversity of pest species was reported in maize by Ong'amo et al. (2006) in Kenya. The most dominant species in Kenya are Chilo partellus (Lepidoptera: Pyralidae) and Busseola fusca (Lepidoptera: Noctuidae), although they differ in dominance between the agro-climatic zones and between seasons. Since maize is grown in Kenya in highland tropics and moist transitional zones, it has a high potential to be attacked by these pests (De Groote, 2002). In Zambia, B. fusca prefers wet weather and cooler temperatures (Okech et al., 1994). In Cameroon, B. fusca occurs mostly in the lowland and coastal forests (Ndemah et al., 2007). 
Table 1.1: Important lepidopteran pests of grain crops in Africa.

\begin{tabular}{|c|c|c|}
\hline Region & Species & Host plant \\
\hline \multirow{7}{*}{$\begin{array}{l}\text { East Africa } \\
\text { (Seshu Reddy, } \\
\text { 1998) }\end{array}$} & $\begin{array}{l}\text { Sesamia calamistis Hampson } \\
\text { (Noctuidae) }\end{array}$ & \multirow[t]{7}{*}{$\begin{array}{l}\text { Maize and } \\
\text { sorghum }\end{array}$} \\
\hline & $\begin{array}{l}\text { Sesamia cretica Lederer } \\
\text { (Noctuidae) }\end{array}$ & \\
\hline & $\begin{array}{l}\text { Busseola fusca (Fuller) } \\
\text { (Noctuidae) }\end{array}$ & \\
\hline & $\begin{array}{l}\text { Eldana saccharina Walker } \\
\text { (Pyralidae) }\end{array}$ & \\
\hline & $\begin{array}{l}\text { Chilo partellus (Swinhoe) } \\
\text { (Pyralidae) }\end{array}$ & \\
\hline & $\begin{array}{l}\text { Chilo orichalcociliellus (Strand) } \\
\text { (Pyralidae) }\end{array}$ & \\
\hline & $\begin{array}{l}\text { Coniesta ignefusalis (Hampson) } \\
\text { (Pyralidae) }\end{array}$ & \\
\hline \multirow{7}{*}{$\begin{array}{l}\text { West Africa } \\
\text { (Bosque-Pérez \& } \\
\text { Schulthess, } \\
\text { 1998) }\end{array}$} & B. fusca & \multirow{7}{*}{$\begin{array}{l}\text { Maize, sorghum, } \\
\text { millet, rice and } \\
\text { sugar cane }\end{array}$} \\
\hline & S. calamistis \& Sesamia spp. & \\
\hline & Eldana saccharina & \\
\hline & Chilo partellus & \\
\hline & Coniesta ignefusalis & \\
\hline & Mussidia nigrivenella (Ragonot) & \\
\hline & (Pyralidae) & \\
\hline \multirow{4}{*}{$\begin{array}{l}\text { Central Africa } \\
\text { (Bosque-Pérez \& } \\
\text { Schulthess, } \\
1998 \text { ) }\end{array}$} & B. fusca & \multirow[t]{4}{*}{ Maize } \\
\hline & S. calamistis & \\
\hline & C. partellus & \\
\hline & C. orichalcociliellus & \\
\hline \multirow{5}{*}{$\begin{array}{l}\text { Southern Africa } \\
\text { (Kfir, 1998) }\end{array}$} & B. fusca & \multirow{5}{*}{$\begin{array}{l}\text { Maize and } \\
\text { sorghum }\end{array}$} \\
\hline & S. calamistis & \\
\hline & C. partellus & \\
\hline & C. orichalcociliellus & \\
\hline & E. saccharina & \\
\hline
\end{tabular}




\subsubsection{Stem borer pests of maize and sorghum in southern Africa}

Busseola fusca is one of the most important pests of maize and sorghum in South Africa (Kfir, 1998). Other important lepidopteran pests in South Africa are the spotted stem borer, C. partellus and the pink stem borer, Sesamia calamistis (Lepidoptera: Noctuidae), which also attack maize and sorghum (Kfir, 1998; Van den Berg \& Drinkwater, 2000; Kfir et al., 2002). Van Rensburg \& Bate (1987) noted varying levels of yield loss between farms, ranging from no losses to total crop loss due to $B$. fusca in maize. In Zimbabwe, Sithole (1987) estimated yield losses of between 30 and 70\% where no insecticides were applied, but less than $30 \%$ crop loss where insecticides were applied.

\subsection{Busseola fusca as a pest of maize in Africa}

\subsubsection{Distribution}

Busseola fusca is an indigenous pest species in tropical Africa (Mohyuddin \& Greathead, 1970; Harris \& Nwanze, 1992; Kfir et al., 2002), attacking several grain crop species in Africa south of the Sahara (Harris, 1989). This species is usually the dominating species in highaltitude regions (Van Rensburg \& Bate, 1987) but it also occurs at low attitudes in East Africa (Calatayud et al., 2014) and Zimbabwe (Sithole, 1989). This species is therefore largely found in the cooler eco-zones of East and southern Africa and in mid-altitude and highland areas (Kfir et al., 2002). While B. fusca has been reported at higher altitudes (>600 $\mathrm{m}$ a.s.I.) in East and southern Africa (Nye, 1960; Sithole, 1989), in West Africa it was reported to occur from sea level to $>2000 \mathrm{~m}$ (Tams \& Bowden, 1953). In southern Africa, $B$. fusca has been reported to occur at low-altitude elevations in coastal regions (Van Rensburg, 1997; Waladde et al., 2002) up to the highlands of Lesotho (2131 m) (Ebenebe et al., 1999a). In Eritrea, B. fusca mostly occurs at altitudes above 1500 m (Haile \& Hofsvang, 2001).

The distribution of stem borer populations is likely to be influenced by temperature, rainfall and humidity, with temperature as the most important factor (Sithole, 1987). Elevation affects the physical environment such as temperature and relative humidity in an area, thus affecting the development and distribution of an insect (Sithole, 1987). 


\subsubsection{Pest status}

Most of the damage done by $B$. fusca larvae is feeding on whorl leaves and stem tunnelling (Appert, 1970; Bosque-Perez \& Mareck, 1991; Kfir, 1998). Stem tunnelling may have a weakening effect on the stem causing it to break and plants to lodge (Appert, 1970; BosquePerez \& Mareck, 1991; Harris \& Nwanze, 1992; Kfir, 1998). Stem damage interferes with translocation of nutrients and metabolites in the plant, thus having an effect on plant growth and also development of grains (Appert, 1970; Bosque-Perez \& Mareck, 1991; Kfir, 1998). The growing points of very young maize plants may also be killed by larvae (Appert, 1970; Bosque-Perez \& Mareck, 1991; Kfir, 1998) thus creating 'dead heart' symptoms (Harris \& Nwanze, 1992). Maize ears are also directly damaged by larvae (Bosque-Perez \& Mareck 1991; Harris \& Nwanze, 1992; Kfir, 1998) and damage can also cause malformation of the grains (Appert, 1970; Bosque-Perez \& Mareck, 1991; Kfir, 1998) thus producing low quality maize for consumption. Infestations by stem borers increase the incidence and severity of stalk rots in maize (Bosque-Perez \& Mareck, 1991). Yield loss estimates may vary with region, B. fusca infestation levels and plant developmental stages (Van Rensburg \& Flett, 2008).

Yield reduction by stem borers depends on conditions such as the plant growth stage, number of larvae per plant and the reaction of the plant to feeding of the stem borer (Appert, 1970; Bosque-Perez \& Mareck, 1991). Yield losses vary between different regions. In Kenya, Hassan et al. (1998) estimated the average loss due to stem borer infestations in low to medium potential areas to be between 26.8 and $27.9 \%$ and for dry mid-altitude areas to be $18 \%$. Ong'amo et al. (2006) reported $10 \%$ loss due to $B$. fusca in highland tropics and moist transitional and mid-altitude zones, but only $1 \%$ loss in low potential zones (dry midaltitude and lowland tropics) of Kenya. Dabrowski (1985) reported yield loss between 15 - 78 $\%$ in Kenya. Usua (1968) reported that one or two larvae per maize plant resulted in yield loss up to $25 \%$ in south-western Nigeria.

\subsubsection{Effect of climate on Busseola fusca}

Climate change is described as a direct or indirect alteration of the environment through anthropogenic activities (IPCC, 2007). Climate change can lead to habitat destruction and fragmentation affecting population dynamics of insects in an area (Thomas et al., 2004; 
Dover \& Settele, 2009). Insect herbivores are expected to suffer direct and indirect effects of climate change through the changes experienced by their host plants (Cornelissen, 2011).

The global mean annual temperatures have been estimated to increase by $1^{\circ} \mathrm{C}$ by 2025 and $3^{\circ} \mathrm{C}$ by the end of the next century (IPCC, 1990a, b, 2007). Increased temperatures may result in rapid growth and development of insects, thus resulting in rapid increase in pest populations over time. Rising temperatures may also lead to earlier infestations by pests and create new niches for insect pests (Sharma, 2010). Lower temperatures on the other hand may limit the geographical distribution of insects (Hill, 1987). According to Sharma (2010), global warming and climate changes will affect the following: geographical ranges of pests, diapause duration, population growth rate, changes in insect-host plant interactions, rates of invasion by non-native pests, changes in diversity, changes in synchrony between insect pests and their host plants, different host introductions, and reduced effectiveness of crop protection technologies.

Future climate change may therefore have a significant effect on the interactions between $B$. fusca and its host plants. Changing rainfall patterns and ambient temperatures, due to climate change, will lead to varying planting dates which in turn will affect the phenology of maize at the landscape level, thereby affecting current management practices (Hassan et al., 1998; De Groote, 2002).

\subsubsection{Control}

Apart from environmental factors such as soil fertility and rainfall, the success of maize production also depends on the time of planting, maize genotype, fertiliser application and weed and pest control. When used properly, insecticides may be effective against pests. Application of pesticides is important but is not always practical on small farms (Warui \& Kuria, 1983). Chemical control of stem borer larvae at advanced growth stages may not be effective because the larvae are protected within the stem. However, first instar larvae can be controlled effectively since they feed in plant whorls for a period of $7-14$ days before they migrate to neighbouring plants or to feed in stems of plants (Critchley et al., 1997).

Various host plant resistance and cultural control strategies have been implemented with partial or local success but none have been proven to provide really effective control of stem borers of maize (Van den Berg et al., 1998; Kfir et al., 2002). Crop residues play an important role in off-season survival of $B$. fusca and C. partellus. Mally (1920) suggested a 
cultural control method of crop residue destruction by means of ploughing of maize stubble, in order to destroy overwintering larvae. Slashing maize and sorghum may result in a $70 \%$ reduction in $B$. fusca and $C$. partellus numbers while further ploughing and discing may destroy a further 19\% in maize (Kfir et al., 1989; Kfir, 1990). Adesiyun \& Ajayi (1980) suggested that partial burning of stalks or spreading of stalks on the ground during the dry season may help to control stem borer larvae inside stalks.

Different planting dates have been used in pest management strategies with the aim to reduce stem borer numbers in maize (Van Rensburg et al., 1985; Ebenebe et al., 1999b). For example, earlier planting can ensure that plants are at their most susceptible stage (midwhorl) when the moth flight activity of $B$. fusca is the lowest in South Africa (Van Rensburg et al., 1985). Many farmers experience less stem borer damage in maize due to early planting dates (Van Rensburg et al., 1988). Van Rensburg et al. (1987) reported that B. fusca infestation pressure was higher in late-planted maize, with the highest number of eggs laid on plants 3 - 4 weeks after seedling emergence. Even though moths prefer maize plants of a certain age they do lay eggs on plants of any age if the area is isolated and if no plants of other ages are available (Van Rensburg et al., 1987). In Ethiopia, Gebre-Amlak et al. (1989) observed a positive correlation between crop loss due to $B$. fusca and late planting dates.

Biological control of $B$. fusca and $C$. partellus has been attempted with Cotesia spp. However, in Kenya B. fusca was not effectively parasitised by the parasitoid Cotesia sesamiae (Cameron) (Hymenoptera: Braconidae) and the exotic parasitoid, Cotesia flavipes Cameron (Hymenoptera: Braconidae), which were introduced in a classical biocontrol program. This parasitoid is only effective in certain areas of Kenya (Kfir, 1995).

Intercropping methods have helped to reduce numbers of eggs and larval populations of stem borers, thus resulting in a lower crop loss when different plants were used (Schulthess et al., 2004; Chabi-Olaye et al., 2005a, b). More recently, the push-pull management strategy has been deployed in East Africa and was shown to be effective against stem borers in that region (Khan et al., 2000; Pickett et al., 2013). The push-pull strategy uses plants that trap or repel pests and also attract predators or parasitic insects by means of semio-chemicals emitted by companion plants (Picket et al., 2013).

Another control method used for stem borers are genetically modified Bt-maize that contains the gene of the soil bacterium Bacillus thuringiensis (Bt). This method has been most effective on $B$. fusca larvae and was shown to have reduced the pest status of this species in South Africa since the release of Bt-maize in 1998 (Gouse et al., 2005; Kruger et al., 
2012). Busseola fusca has, however, developed resistance to Bt-maize in South Africa (Van Rensburg, 2007; Kruger et al., 2012).

\subsection{Life cycle of Busseola fusca}

The life cycle of $B$. fusca is shown in figure 1.1. The emergence of moths occurs usually around late afternoon since they are active at night (Unnithan, 1987; Harris \& Nwanze, 1992). The males tend to emerge before the females as observed by Calatayud et al. (2007). After emergence, female moths release a pheromone to attract the males (Harris \& Nwanze, 1992; Frérot et al., 2006). Mating is quite simple and rapid and generally takes place during the first six hours of the night (Calatayud et al., 2007). Males can mate several times, but fertilise the eggs with only one spermatophore per mating. Females mate only once per night (Unnithan \& Paye, 1990) and disperse afterwards in search of a suitable host for oviposition. Eggs are laid under the inner surfaces of leaf sheaths in batches (Unnithan, 1987; Harris \& Nwanze, 1992) and the number of eggs varies greatly. Reports of the number of egg batches as well as total number of eggs laid per female vary greatly, for example, 600 - 800 eggs per female in 30 - 100 batches (Unnithan, 1987); 1 - 140 egg batches with a maximum of 891 eggs per female (Mally, 1920), 30 - 100 egg batches and 1000 eggs per female (Harris, 1962); 70 egg batches and 568 eggs per female (Ingram, 1958) and 100 800 eggs per female (Van Rensburg et al., 1987; Kruger et al., 2014). Males tend to live slightly longer than the females (Unnithan, 1987).

Larvae generally take about a week to emerge after oviposition, thereafter dispersing over the leaves to settle on their host plants before they start to feed on whorl leaves. Most larvae up until the $4^{\text {th }}$ instar will feed in the plant whorl after which they move to the stems (Van Rensburg et al., 1987). They feed for about 3 - 5 weeks inside the stems and maize ears producing tunnels before entering the pupal stage (Harris \& Nwanze, 1992). The duration of the larval stage is about 24 - 54 days depending on temperature (Calatayud et al., 2007). Before pupation, larvae will create an exit hole for the moths by tunnelling towards the outside of the stem but leaving the outer epidermal layer intact (Harris \& Nwanze, 1992).

Female pupae are bigger than the male pupae and can be distinguished by the genital scars on sternum 8 of females and sternum 9 of males (Harris \& Nwanze, 1992). Male and female pupae are shown in figure 1.2. The pupation period is about 9 - 14 days depending on the temperature (Harris \& Nwanze, 1992; Onyango \& Ochieng'-Odero, 1994; Ratnadass et al., 2001). The life cycle of $B$. fusca is completed within 7 - 8 weeks if the conditions are favourable (Harris \& Nwanze, 1992). Not all of the larvae pupate, some of them enter 
diapause. In South Africa, B. fusca overwinters as diapause larvae from April - October (dry winter season) inside the lower dry stalks just beneath the ground surface (Kfir, 1988; 1990; 1991; Kfir et al., 1989).

The first seasonal flight of $B$. fusca moths starts in South Africa during early spring (September) (Van Rensburg et al., 1985; Van Rensburg, 1997). The second seasonal moth flight occurs largely after flowering of early planted maize plants and more towards the end of the crop production season. There are usually only two seasonal flights per year but a third may also occur. This flight and the infestation that follows are not regarded as economically important (Van Rensburg et al., 1985; Van Rensburg, 1997). Third-generation moths cannot find suitable host plants for oviposition due to desiccation of the old plants, decreasing temperature and humidity, and young larvae unable to feed on older plants (Van Rensburg, 1997).

\subsection{Diapause}

During unfavourable conditions, stem borer larvae are able to enter diapause. To ensure the survival of larvae during unfavourable conditions, mature larvae can enter diapause for six months or more during dry or cold periods before they pupate. Diapause larvae usually occur in stems and stubble (Harris \& Nwanze, 1992). Most larvae will reside in the lower parts of stems just underneath the soil surface for protection against natural enemies and unfavourable climatic conditions (Kfir, 1988, 1990; Kfir et al., 1989).

Lees (1955) indicated that the most important factors playing a role in inducing diapause in insects are photoperiod, temperature and diet. These factors may work together or alone, depending on how the insect react to unfavourable conditions, to induce diapause. Usually higher temperatures won't cause diapause in arthropods but lower temperature can slow down development or growth in an insect (Lees, 1955). Temperature may play a role in inducing diapause in arthropods but not for tropical insects.

According to Usua (1973), diapause can be induced in B. fusca through food, for example if the constituents of maize tissue have been altered through environmental conditions. Fewer larvae are reported to diapause when maize stems have a high water, high protein and low carbohydrate content (Usua, 1973). Because of the high carbohydrate content inside maize stems, larvae can store fat in the cells of the body. Usua (1973) also noted that factors such as maturity and food composition played an important role in initiating diapause. Okuda 
(1990) indicated that soil moisture plays an important role in terminating diapause for $B$. fusca populations. Van Rensburg and Van Rensburg (1993) described how temperature, humidity and mainly photoperiod can be used to manipulate the diapause process in $B$. fusca larvae.

In Zimbabwe, Smithers (1960) has found B. fusca larvae in diapause in maize stems 25 - 60 $\mathrm{cm}$ above the soil surface. The reason they are found near the soil is a reaction to temperature found only in colder regions. It may also be that during the winter, the stem base may have a higher temperature inside than on the soil surface. During winter, the stem may have higher humidity than outside as well as the stem base also having a higher humidity level than the upper parts of stem. Since diapause may also occur as a droughtsurvival mechanism, diapause larvae may also use the base of the stem to avoid desiccation (Van Rensburg et al., 1987).

Diapausing larvae lose their typical creamy-brown colour during the diapause stage. Kfir (1991) noticed that during diapause, borer larvae became less active and lost their pigmentation, therefore turning dirty white colour. A possible reason may be that before entering diapause, larvae accumulate large energy reserves (mostly fat) thus causing a loss of pigmentation (Kfir, 1991). Diapausing larvae also lose weight during the diapause stage through the consumption of energy reserves while in the diapause stage (Kfir, 1991).

During diapause the insect consumes its body fat thus causing weight loss which results in a decrease in body size. During normal conditions of growth the external skeleton becomes too small for the insect, therefore the insect needs to moult (Kfir, 1991). Insects moult because their exoskeleton (external skeleton) can't expand as the insect grows larger. Nondiapausing larvae normally have six moults but diapausing larvae have additional six or seven moults. Some larvae may therefore moult as many as 13 times before entering pupation (Kfir, 1991). To terminate diapause, a combination of temperature, humidity and photoperiod is needed in which photoperiod is the most important (Van Rensburg \& Van Rensburg, 1993). When the conditions are favourable the diapause stage will end, followed by the pupal stage.

Female moths of diapause larvae have fewer eggs in their ovaries than moths originating from non-diapausing larvae. Van Rensburg et al. (1987) indicated that the egg batches of spring moths were smaller than those of summer moths. A possible reason might be that the body energy reserves of spring moths are smaller than that of the summer moths because 
the energy reserves are used during diapause. During a study done by Kfir (1991), a positive correlation was observed between body mass and eggs in the ovaries of $B$. fusca moths.

\subsection{Oviposition}

Busseola fusca moths lay their eggs in batches underneath leaf sheaths, behind the vertical edges and also underneath outer husk leaves of maize ears (Mally, 1920). Moths show an oviposition preference for 3 - 5 week old maize plants (Van Rensburg et al., 1987; Van Rensburg \& Van Rensburg, 1993), but oviposition can occur on plants of other ages if plants of the preferred age are not available. These moths find the youngest unfolded leaf sheath of maize plants the most attractive with the tendency that the preferred oviposition site moves gradually upwards with the growth of the plant. Larger plants have more oviposition sites and may accommodate bigger egg masses and improved survival of larvae (Harris \& Nwanze, 1992). Increased plant age is correlated with increasing occurrence of egg batches higher up on the plant (Van Rensburg et al., 1987). With age, the leaves become looser around the stem, attracting ovipositional moths (Van Rensburg et al., 1987).

\subsection{Temperature dependent development and reproduction}

Temperature has an effect on the development, survival and reproduction of insects. Studies on the effect of temperature on $B$. fusca are still inadequate. This study is important for pest management strategies and for the prediction of outbreaks of this species.

Temperature is an environmental condition that causes specific morphological and physiological responses in individuals of a species (Hallman \& Denlinger, 1998; Huey \& Berrigan, 2001; Begon et al., 2006; Golizadeh et al., 2007). Development occurs within a specific temperature range and is best performed at an optimum temperature. Development rate decreases as the temperature decreases or deviates from the optimum (Begon et al., 2006). Changes in performance are caused by metabolic changes in an organism. For each $10{ }^{\circ} \mathrm{C}$ rise in temperature, the rate of biological enzymic processes nearly doubles until around $20{ }^{\circ} \mathrm{C}$ thereafter the rate will increase less rapidly with higher temperatures (an exponential curve on a plot of performance rate against temperature can show this relationship) (Begon et al., 2006). The reason for increase in enzymic processes is the increased speed of molecular movement caused by high temperatures that speeds up chemical reactions in insects. Insects have a functional temperature range at which they can 
live at their best. Yet, outside that temperature range the conditions are regarded as extremes that cause impaired function and ultimately death for insects (Begon et al., 2006).

The effect of temperature on growth rate (increase in mass) and development (progression through life cycle stages), and on final body size drive the main ecological activities of survival, reproduction and growth. The relationship between growth rates, development and temperature are effectively linear, showing only slight deviations. The temperatures experienced by an organism, is indicated as degree-days (Begon et al., 2006).

The final size of a fully grown organism will be determined by the rates of growth and development. If the rates of growth and development are rapid, the final size of the fully grown organism will be smaller than slower growing and developing organisms of the same species. Therefore, since an organism responds differently in terms of growth and development with varying temperatures, the full grown size of the organism will also be affected by temperature (Begon et al., 2006).

Temperature affects the rate of survival, reproduction, population growth and development (Roy et al., 2003). Many different models have been created to describe the relationship between temperature and insect development and growth (Briere \& Pracros, 1998; Roy et al., 2002; Golizadeh et al., 2007). If the adaptation of insects to environmental conditions is known, pest management can predict the timing of development, reproduction, dormancy (diapause) and migration (Nechols et al., 1999; Roy et al., 2002). Thus, determining the relationship between temperature and rate of development and reproduction is important in studies of population dynamics of pests. Population studies have several applications such as analysing population stability and structure, estimating extinction probabilities, predicting life history evolution, predicting outbreaks of pest species, and examining the dynamics of colonising or invading species (Vargas et al., 1997).

The temperature thresholds for B. fusca published differ between studies (Nye, 1960; Usua, 1968, 1973; Harris \& Nwanze, 1992; Dixon et al., 2009). Thermal requirements may, however, vary among different populations (Lee \& Elliot, 1998, Gomi et al., 2003) because of different geographical areas with variable climate conditions due to a gradient of latitude (Honék, 1996, Addo-Bediako et al., 2000, Chen \& Kang, 2004). Honék (1996) has shown that in subtropical and temperate zones the lower development threshold decreases with increasing geographical latitude. The thermal constants and lower and upper threshold temperatures of $B$. fusca determined for populations in different geographical areas will 
enable the prediction of the impact of climate change on the distribution and population growth of this pest.

\subsection{Objectives of this study}

\subsubsection{General objective}

The main objective of the study is to evaluate the effect of temperature on the development and reproduction of Busseola fusca (Lepidoptera: Noctuidae).

\subsubsection{Specific objectives}

The specific objectives were to determine:

- the development rate of $B$. fusca at different constant temperatures

- to determine the number of degree-days $\left({ }^{\circ} \mathrm{D}\right)$ required for each stage to complete development as well as for overall egg-to-adult development

- to determine the number of larval instars by measuring larval head capsule width and to develop criteria to determine the specific instar of $B$. fusca

- to determine the effect of different temperatures on reproduction of $B$. fusca

The results of this study are presented in the form of chapters with the following titles:

- Chapter 2: The effect of temperature on the development of Busseola fusca (Lepidoptera: Noctuidae)

- Chapter 3: The effect of temperature on reproduction of Busseola fusca (Lepidoptera: Noctuidae) 


\subsection{References}

Adams, R.M., Rosenzweig, C., Peart, R.M., Richie, J.T., McCarl, B.A., Glyer, J.D., Curry, R.B., Jones, J.W., Boote, K.J. \& Allen Jr, L.H. 1990. Global climate change and US agriculture. Nature 345: 219-224.

Addo-Bediako, A., Chown, S.L. \& Gaston, K.J. 2000. Thermal tolerance, climatic variability and latitude. Proceedings of the Royal Society of London, Series B, Biological Sciences, 267: 739-745.

Adesiyun, A.A. \& Ajayi, O. 1980. Control of the sorghum stem borer, Busseola fusca, by partial burning of the stalks. Tropical Pest Management 26: 113-117.

Aggarwal, P.K. \& Mall, R.K. 2002. Climate change and rice yields in diverse agroenvironments of India. II. Effect of uncertainties in scenarios and crop models on impact assessment. Climate Change 52: 331-343.

Appert, J. 1970. Insects harmful to maize in Africa and Madagascar. Madagascar Institute of Agronomic Research. 71 p.

Begon, M., Towsend, C.R. \& Harper, J.L. 2006. Ecology: from individuals to ecosystems. $4^{\text {th }}$ ed. Blackwell: Oxford, UK. 738 p.

Bosque-Pérez, N.A. \& Mareck, J.H. 1991. Effect of the stem borer Eldana saccharina (Lepidoptera: Pyralidae) on the yield of maize. Bulletin of Entomological Research 81: 243247.

Bosque-Pérez, N.A. \& Schulthess, F. 1998. Maize: West and Central Africa. (In Polaszek, A., ed. African cereal stemborers: economic importance, taxonomy, natural enemies and control. CTA/CABI, Wallingford. UK. p. 11-24).

Briere, J.F. \& Pracros, P. 1998. Comparison of temperature-dependent growth models with the development of Lobesia botrana (Lep., Tortricidae). Environmental Entomology 27: 94101.

Calzadilla, A., Zhu, T., Rehdanz, K., Tol, R.S.J. \& Ringler, C. 2013. Economy-wide impacts of climate change on agriculture in sub-Saharan Africa. Ecological Economics 93: 150-165. 
Calzadilla, A., Zhu, T., Rehdanz, K., Tol, R.S.J. \& Ringler, C. 2014. Climate change and agriculture: impacts and adaptation options in South Africa. Water Resources and Economics 5: 24-48.

Calatayud, P.A., Guénégo, H., Le Ru, B.P, Silvain, J.F. \& Frérot, B. 2007. Temporal patterns of emergence, calling behaviour and oviposition period of the maize stem borer, Busseola fusca (Fuller) (Lepidoptera: Noctuidae). Annales de la Societe Entomologique de France 43: 63-68.

Calatayud, P.A., Le Ru, B.P, Van den Berg, J. \& Schulthess, F. 2014. Ecology of the African maize stalk borer, Busseola fusca (Lepidoptera: Noctuidae) with special reference to insect-plant interactions. Insects 5: 539-563.

Chabi-Olaye, A., Nolte, C., Schulthess, F. \& Borgemeister, C. 2005a. Abundance, dispersion and parasitism of the noctuid stem borer Busseola fusca (Fuller) in mono- and intercropped maize in the humid forest zone of southern Cameroon. Bulletin of Entomological Research 95: 169-177.

Chabi-Olaye, A., Nolte, C., Schulthess, F. \& Borgemeister, C. 2005b. Relationships of intercropped maize, stem borer damage to maize yield and land-use efficiency in the humid forest of Cameroon. Bulletin of Entomology Research 95: 417-427.

Chen, B. \& Kang, L. 2004. Variation in cold hardiness of Liriomyza huidobrensis (Diptera: Agromyzidae) along the latitudinal gradients. Environmental Entomology 33: 155-164.

Chmielewski, F., Muller, A. \& Bruns, E. 2004. Climate changes and trends in phenology of fruit trees and field crops in Germany, 1961-2000. Agricultural and Forest Meteorology 121: 69-78.

Cornelissen, T. 2011. Climate change and its effects on terrestrial insects and herbivory patterns. Neotropical Entomology 40:155-163.

Critchley, B.R., Hall, D.R., Farman, D.I., McVeigh, L.J., Mulaa, M.A. \& Kalama, P. 1997. Monitoring and mating disruption of the maize stalkborer, Busseola fusca, in Kenya with pheromones. Crop Protection 16: 541-548. 
Dabrowski, Z.T. 1985. Stem borers on maize and their control: present and future alternatives. Nairobi, Kenya: International Centre of Insect Physiology and Ecology (PESTNET). $24 \mathrm{p}$.

De Groote, H. 2002. Maize yield losses from stemborers in Kenya. Insect Science and its Application 22: 89-96.

Dixon, A.F.G., Honek, A., Keil, P., Kotela, M.A.A., Sizling, A.L. \& Jorosik, V. 2009. Relationship between the minimum and maximum temperature thresholds for development in insects. Functional Ecology 23: 257-264.

Dover, J. \& Settele, J. 2009. The influences of landscape structure on butterfly distribution and movement: a review. Journal of Insect Conservation 13: 3-27.

DWAF (Department of Water Affairs and Forestry). 2004. National Water Resource Strategy, South Africa, Pretoria.

Ebenebe, A.A., Van den Berg, J. \& Van der Linde, T.C de K. 1999a. Distribution and relative abundance of stalk borers of maize and sorghum in Lesotho. African Plant Protection 5: 77-82.

Ebenebe, A.A., Van den Berg, J. \& Van der Linde, T.C de K. 1999b. Effect of planting date of maize on damage and yield loss caused by the stalk borer, Busseola fusca (Fuller) (Lepidoptera: Noctuidae) in Lesotho. South African Journal of Plant and Soil 16:180-185.

FAO (Food and Agricultural Organization of the United Nations). 2008. Water and the rural poor: interventions for improving livelihoods in sub-Saharan Africa. (In Faurès, J.M. \& Santini, G., eds. Rome: Food and Agricultural Organization of the United Nations (FAO) and International Fund for Agricultural Development (IFAD)).

FAO (Food and Agricultural Organization of the United Nations). 2011. Strengthening Capacity for Climate Change Adaptation in Agriculture: Experience and Lessons from Lesotho. Rome: Food and Agricultural Organization of the United Nations. 
Frérot, B., Félix, A.E., Ene, S., Calatayud, P.A., Le Rü, B.P. \& Guenego, H. 2006.

Courtship behaviour of the African maize stem borer: Busseola fusca (Fuller) (Lepidoptera: Noctuidae) under laboratory conditions. Annales de la Société Entomologique de France 42: 413-416.

Gebre-Amlak, A., Sigvald, R. \& Petersson, J. 1989. The relationship between sowing date, infestation and damage by the maize stalk borer, Busseola fusca (Noctuidae), on maize in Awassa, Ethiopia. Tropical Pest Management 35: 143-145.

Golizadeh, A., Kamali, K., Fathipur, Y. \& Abbasipour, H. 2007. Temperature-dependant development of diamondback moth, Plutella xylostella (Lepidoptera: Plutellidae) on two brassicaceous host plants. Insect Science 6: 71-75.

Gomi, T., Inudo, M. \& Yamada, D. 2003. Local divergence in developmental traits within a trivoltine area of Hyphantria cunea Drury (Lepidoptera: Arctiidae). Entomological Science 6: 71-75.

Gouse, M., Pray, C.E., Kirsten, J. \& Schimmelpfenning, D. 2005. A GM subsistence crop in Africa: the case of Bt white maize in South Africa. International Journal of Biotechnology 7: 84-94.

Haile, A. \& Hofsvang, T. 2001. Survey of lepidopterous stem borer pests of sorghum, maize and pearl millet in Eritrea. Crop Protection 20: 151-157.

Hallman, G.J. \& Denlinger, D.L. 1998. Introduction: temperature sensitivity and integrated pest management. (In Hallman, G.J. \& Denlinger, D.L., eds. Temperature sensitivity in insects and application in integrated pest management. Boulder: Westview Press. p. 1-5).

Harris, K.M. 1962. Lepidopterous stem borers of cereals in Nigeria. Bulletin Entomological of Research 53: 139-171.

Harris, K.M. 1989. Recent advances in sorghum and pearl millet stem borer research. (In ICRISAT (International Crops Research Institute for the Semi-Arid Tropics). International Workshop on Sorghum Stem Borers, 17-20 Nov 1987, ICRISAT Center, India. Patancheru, A.P. 502 324, India: ICRISAT. p. 9-16). 
Harris, K.M. \& Nwanze, K.F. 1992. Busseola fusca (Fuller), the African maize stem borer: a handbook of information. Information Bulletin no. 33. India: International Crops Research Institute for the Semi-Arid Tropics. Wallingford, UK: CAB International. 84 p.

Hassan, R.M., Corbett, J.D. \& Njoroge, K. 1998. Maize technology development and transfer: a GIS application for research planning in Kenya. Oxon, UK. p. 43-68.

Hill, D.S. 1987. Agricultural insect pests of temperate regions and their control. Cambridge University Press: Cambridge, UK. 659 p.

Honék, A. 1996. Geographical variation in thermal requirements for insect development. European Journal of Entomology 93: 303-312.

Hu, Q., Weiss, A., Feng, S. \& Baenziger, P.S. 2005. Earlier winter wheat heading dates and warmer spring in the US Great Plains. Agricultural and Forest Meteorology 135: 284290.

Huey, R.B. \& Berrigan, D. 2001. Temperature, demography, and ectotherm fitness. American Naturalist 158: 204-210.

Hussain, I. \& Hanjra, M.A. 2004. Irrigation and poverty alleviation: review of the empirical evidence. Irrigation and Drainage 53: 1-15.

Ingram, W.R. 1958. The lepidopterous stalk borers associated with Gramineae in Uganda. Bulletin of Entomological Research 49: 367-383.

IPCC (Intergovernmental Panel on Climate Change). 1990a. Climate change: the IPCC scientific assessment. Intergovernmental Panel on Climate Change. Geneva and Nairobi, Kenya: World Meteorological Organization and UN Environment Program. 365 p.

IPCC (Intergovernmental Panel on Climate Change). 1990b. The potential impacts of climate change on agriculture and forestry. Intergovernmental Panel on Climate Change. Geneva and Nairobi, Kenya: World Meteorological Organization and UN Environment Program. $55 \mathrm{p}$.

IPCC (Intergovernmental Panel on Climate Change). 2007. Impacts, adaptation and vulnerability. (In Parry, M.L., Canziani, O.F., Palutikof, J.P., Van der Linden, P.J. \& 
Hanson, C.E., eds. Contribution of Working Group II to the Fourth Assessment Report of the IPCC. Cambridge University Press: Cambridge, UK. 976 p).

Jørgen, E.O. \& Marco, B. 2002. Consequences of climate change for European agricultural productivity, land use and policy. European Journal of Agronomy 16: 239-262.

Kfir, R. 1988. Hibernation by the lepidopteran stalk borers, Busseola fusca and Chilo partellus on grain sorghum. Entomologia Experimentalis et Applicata 48: 31-36.

Kfir, R. 1990. Prospects for cultural control of the stalk borers, Chilo partellus (Swinhoe) and Busseola fusca (Fuller), in summer grain crops in South Africa. Journal of Entomological Society of Southern Africa 53: 41-47.

Kfir, R. 1991. Duration of diapause in the stem borers, Busseola fusca and Chilo partellus. Entomologia Experimentalis et Applicata 61: 265-270.

Kfir, R. 1995. Parasitoids of the African stem borer, Busseola fusca (Lepidoptera: Noctuidae) in South Africa. Bulletin of Entomological Research 85: 369-377.

Kfir, R. 1998. Maize and grain sorghum: southern Africa. (In Polaszek, A., ed. African cereal stem borers: economic importance, taxonomy, natural enemies and control. $C A B$ International, Wallingford. p. 29-37).

Kfir, R., Van Hamburg, H. \& Van Vuuren, R. 1989. Effect of stubble treatment on the postdiapause emergence of the stalkborer Chilo partellus (Swinhoe) (Lepidoptera: Pyralidae). Crop Protection 8: 289-292.

Kfir, R., Overholt, W.A., Khan, Z.R. \& Polaszek, A. 2002. Biology and management of economically important lepidopteran cereal stem borers in Africa. Annual Review of Entomology 47: 701-731.

Khan, Z.R., Pickett, J.A., Van den Berg, J., Wadhams, L.J. \& Woodcock, C.M. 2000. Exploiting chemical ecology and species diversity: stem borer and striga control for maize and sorghum in Africa. Pest Management Science 56: 957-962. 
Kruger, M., Van Rensburg, J.B.J. \& Van den Berg, J. 2012. Transgenic Bt maize: farmers' perceptions refuge compliance and reports of stem borer resistance in South Africa. Journal of Applied Entomology 136: 38-50.

Kruger, M., Van Rensburg, J.B.J. \& Van den Berg, J. 2014. No fitness costs associated with resistance of Busseola fusca (Lepidoptera: Noctuidae) to genetically modified Bt maize. Crop Protection 55: 1-6.

Lee, J.H. \& Elliott, N.C. 1998. Comparison of developmental responses to temperature in Aphelinus asycyhis (Walker) from two different geographic regions. Southwestern Entomologist 23: 77-82.

Lees, A. D. 1955. The physiology of diapause in arthropods. Cambridge University Press: London. $513 \mathrm{p.}$

Li, Z., Yang, P., Tang, H., Wu, W., Yin, H., Liu, Z. \& Zang, L. 2014. Response of maize phenology to climate warming in Northeast China between 1990 and 2012. Regional Environmental Change 14: 39-48.

Lobell, D., Burke, M., Tebaldi, C., Mastrandrea, M.D., Falcon, W.P. \& Naylor, R.L. 2008. Prioritizing climate change adaptation needs for food security in 2030. Science 319: 607610.

Maes, K. 1997. Taxonomy of lepidopteran cereal stem borers attacking maize and sorghum of Africa. Insect Science and its Application 17: 9-12.

Mally, C.W. 1920. The maize stalk borer, Busseola fusca (Fuller). Bulletin of the Department of Agriculture, Union of South Africa no 3. 111 p.

Matthews, R.B., Kropff, M.J. \& Horie, T. 1997. Simulating the impact of climate change on rice production in Asia and evaluating options for adaptation. Agricultural Systems 54: 399425.

Megenasa, T. 1982. Insect pests of sorghum in Ethiopia. (In Gebrekidan, B., ed. Proceedings of the regional workshop on sorghum improvement in eastern Africa. Nazareth and Debre Zeit, Ethiopia. p. 54-64). 
Mohyuddin, A. I. \& Greathead, D.J. 1970. An annotated list of the parasites of graminaceous stemborers in East Africa, with discussion of their potential in biological control. Entomophaga 15: 241-274.

Molden, M., Frenken, K., Barker, R., de Fraiture, C., Mati, B., Svendsen, M., Sadoff, C. \& Finlayson, M. 2007. Trends in water and agricultural development. (In Molden, D., ed. Water for food, water for life: comprehensive assessment of water management in agriculture. EarthScan, London, (Chapter 2). p. 57-90).

Ndemah, R., Schulthess, F., Le Rü, B. \& Bame, I. 2007. Lepidopteran cereal stemborers and associated natural enemies on maize and wild grass hosts in Cameroon. Journal of Applied Entomology 131: 658-668.

Ndemah, R., Schulthess, F., Korie, S., Borgemeister, C. \& Cardwell, K.F. 2001.

Distribution, relative importance and effect of lepidopterous borers on maize yields in the forest zone and mid-altitudes of Cameroon. Journal of Economic Entomology 94: 14341444.

Nechols, J.R., Tauber, M.J., Tauber, C.A. \& Masaki, S. 1999. Adaptations to hazardous seasonal conditions: dormancy, migration, and polyphenism. (In Huffaker, C.B. \& Gutierrez, A.P., eds. Ecological entomology. Wiley: New York. p. 159-200).

Nye, I.W.R. 1960. The insect pests of graminaceous crops in East Africa. Colonial Research Studies. Her Majesty's Stationary Office, London. 31: 1-48.

Ogden, E. \& Innes, J.L. 2008. Climate change adaptation and regional forest planning in southern Yukon, Canada. Mitigation and Adaptation Strategies for Global Change 13: 833861.

Okech, S.H.O., Neukermans, L.M.N.R. \& Chinsembu, K.C. 1994. Agroecological distribution of major stalk borers of maize in Zambia. Insect Science and its Application 15: 167-172.

Okuda, T. 1990. Significance of water contact as a factor terminating larval diapause in a stem borer, Busseola fusca. Entomologia Experimentalis et Applicata 57: 151-155. 
Ong'amo, G.O., Le Rü, B.P., Dupas, S., Moyal, P., Calatayud, P.A. \& Silvain, J.F. 2006. Distribution, pest status and agroclimatic preferences of lepidopteran stemborers of maize and sorghum in Kenya. Annales de la Société Entomologique de France 42:171-177.

Onyango, F.O. \& Ochieng'-Odero, J.P.R. 1994. Continuous rearing of the maize stemborer Busseola fusca on an artificial diet. Entomologia Experimentalis et Applicata 73: 139-144.

Pickett, J.A., Woodcock, C.M., Midega, C.A.O. \& Khan, Z.R. 2013. Push-pull farming systems. Current Opinion in Biotechnology 26: 125-132.

Polaszek, A. \& Khan, Z.R. 1998. Host plants. (In Polaszek, A., ed. African cereal stem borers: economic importance, taxonomy, natural enemies and control. CTA/CABI, Wallingford. UK. p. 3-10).

Ratnadass, A., Traore, T., Sylla, M. \& Diarra, D. 2001. Improved techniques for massrearing Busseola fusca (Lepidoptera: Noctuidae) on an artificial diet. African Entomology 9: $1-9$.

Roy, M., Brodeur, J. \& Cloutier, C. 2002. Relationship between temperature and developmental rate of Stethorus punctillum (Coleoptera: Coccinellidae) and its prey Tetranychus mcdanieli (Acarina: Tetranychidae). Environmental Entomology 31: 177-187.

Roy, M., Brodeur, J. \& Cloutier, C. 2003. Effect of temperature on intrinsic rates of natural increase $\left(r_{m}\right)$ of a coccinellid and its spider mite prey. Biocontrol 48: 57-72.

Sacks, W.J. \& Kucharik, C.J. 2011. Crop management and phenology trends in the U.S. Corn Belt: impacts on yields, evapotranspiration and energy balance. Agricultural and Forest Meteorology 151: 882-894.

Schulthess, F., Chabi-Olaye, A. \& Gounou, S. 2004. Multi-trophic level interactions in a cassava-maize relay cropping system in the humid tropics of West Africa. Bulletin of Entomological Research 94: 261-272.

Seshu Reddy, K.V. 1998. Maize and sorghum: East Africa. (In Polaszek, A., ed. African cereal stem borers: economic importance, taxonomy, natural enemies and control. CTA/CABI, Wallingford. UK. p. 25-28). 
Sharma, H.C. 2010. Global warming and climate change: impact on arthropod biodiversity, pest management, and food security. (In National Symposium on Perspectives and Challenges of Integrated Pest Management for Sustainable Agriculture, Solan. p. 1-11).

Siebert, S. \& Ewert, F. 2012. Spatio-temporal patterns of phenological development in Germany in relation to temperature and day length. Agricultural and Forest Meteorology 152: 44-57.

Sithole, S.Z. 1987. Maize insect pests in Zimbabwe. Toward Insect Resistant Maize for the Third World. Proceedings of International Symposium on Methodology, Developing Host Plant Resistance Maize Insects. CIMMYT. Mexico: Mexico City. p. 286-288.

Sithole, S.Z. 1989. Sorghum stemborers in southern Africa. International Workshop Sorghum Stem Borers. ICRISAT Sahelian Center, Niamey, Niger. India: Patancheru 502 324, Andra Pradesh, India: International Crop Research Institute for the Semi-Arid Tropics. p. 41-47.

Smithers, C.N. 1960. Some recent observations on Busseola fusca (Fuller) (Lep., Noctuidae) in Southern Rhodesia. Bulletin of Entomological Research 50: 809-819.

Songa, J.M., Overholt, W.A., Mueke, J.M. \& Okello, R.O. 1998. Distribution of stemborer species in semi-arid Eastern Kenya. (In Sixth Eastern and Southern Africa Regional maize conference. p. 117-120).

Susanna, R., Barry, S., Wayne, C. \& Suzanne, B. 2007. Vulnerability and adaptation to climate risks in Ontario agriculture. Mitigation and Adaptation Strategies for Global Change 12: 609-637.

Tams, W.H.T. \& Bowden, J. 1953. A revision of the African species of Sesamia Guenée and related genera (Agrotidae-Lepidoptera). Bulletin of Entomological Research 43: 645678.

Tao, F., Yokozawa, M., Xu, Y., Hayashi, Y. \& Zhang, Z. 2006. Climate changes and trends in phenology and yields of field crops in China, 1981-2000. Agricultural and Forest Meteorology 138: 82-92. 
Thomas, C.D., Cameron, A., Green, R.E., Bakkenes, M., Beaumont, L.J., Collingham, Y.C., Erasmus, B.F.N., Desiqueira, M.F., Grainger, A., Hannah, L., Hughes, I., Huntley, B., Van Jaarsveld, A.S., Midgley, G.F., Miles, L., Ortega-Huerta, M.A., Townsend Peterson, A., Phillips, O.L. \& Williams, S.E. 2004. Extinction risk from climate change. Nature 427: 145148.

Tsimba, R., Edmeades, G.O., Millner, J.P. \& Kemp, P.D. 2013. The effect of planting date on maize: phenology, thermal time durations and growth rates in a cool temperate climate. Field Crops Research 150: 145-155.

United Nations. 2009. United Nations Environment Programme Finance Initiative, Chief Liquidity Series: Water-related Materiality Briefings for Financial Institutions: Agribusiness, Issue 1. UNEP-FI.

Unnithan, G.C. 1987. Development and reproductive biology of the maize stem borer Busseola fusca Fuller (Lepidoptera: Noctuidae). Journal of Applied Entomology 104: 172179.

Unnithan G.C. \& Paye S.O. 1990. Factors involved in mating, longevity, fecundity and egg fertility in the maize stem-borer, Busseola fusca (Fuller) (Lep., Noctuidae). Journal of Applied Entomology 109: 295-301.

Usua, E.J. 1968. The biology and ecology of Busseola fusca and Sesamia species in southwestern Nigeria: Distribution and population studies. Journal of Economic Entomology 61:830-833.

Usua, E.J. 1973. Induction of diapause in the maize stemborer, Busseola fusca. Entomology Experimentalis et Applicata 16: 322-328.

Van den Berg, J. \& Drinkwater, T.W. 2000. Pink stem borer. Plant Protection Series no. 20. ARC-Grain Crops Research Institute, Potchefstroom.

Van den Berg, J., Nur, A.F. \& Polaszek, A. 1998. Cultural control. (In Polaszek, A., ed. African cereal stem borers: economic importance, taxonomy, natural enemies and control. CTA/CABI, Wallingford. UK. p. 333-347). 
Van Rensburg, G.D.J. \& Bate, R. 1987. Preliminary studies on the relative abundance and distribution of the stalk borers Busseola fusca and Chilo partellus. Technical Communication, Department of Agriculture and Water Supply, Republic of South Africa, 212: 49-52.

Van Rensburg, J.B.J. 1997. Seasonal moth flight activity of the maize stem borer, Busseola fusca (Fuller) (Lepidoptera: Noctuidae) in small farming areas of South Africa. Applied Plant Science 11: 20-23.

Van Rensburg, J.B.J. 2007. First report of field resistance by the stem borer, Busseola fusca (Fuller) to Bt-transgenic maize. South African Journal of Plant and Soil 24: 147-151.

Van Rensburg, J.B.J \& Flett, B.C. 2008. A review of research achievements on maize stem borer, Busseola fusca (Fuller) and Diplodia ear rot caused by Stenocarpella maydis (Berk. Sutton). South African Journal of Plant and Soil 27: 74-80.

Van Rensburg, J.B.J. \& Van Rensburg, G.D.J. 1993. Laboratory production of Busseola fusca (Fuller) (Lepidoptera: Noctuidae) and techniques for the detection of resistance in maize plants. African Entomology 1: 25-28.

Van Rensburg, J.B.J, Walters, M.C. \& Giliomee, J.H. 1985. Geographical variation in the seasonal moth flight activity of the maize stalk borer, Busseola fusca (Fuller), in South Africa. South African Journal of Plant and Soil 2: 123-126.

Van Rensburg, J.B.J., Walters, M.C. \& Giliomee, J.H. 1987. Ecology of the maize stalkborer, Busseola fusca Fuller (Lepidoptera: Noctuidae). Bulletin of Entomological Research 77: 255-269.

Van Rensburg, J.B.J., Giliomee, J.H. \& Walters, M.C. 1988. Aspects of the injuriousness of the maize stalk borer, Busseola fusca (Fuller) (Lepidoptera: Noctuidae). Bulletin of Entomological Research 78: 101-110.

Vargas, R.I., Walsh, W.A., Kanehisa, D.T., Jang, E.B. \& Armstrong, J.W. 1997. Demography of four Hawaiian fruit flies (Diptera: Tephritidae) reared at five constant temperatures. Annals of the Entomological Society of America 90: 162-168. 
Waladde, S.M., Van den Berg, J., Botlohle, P.M. \& Mlanjeni, N. 2002. Survey of the abundance and distribution of maize stemborers in the Eastern Cape province of South Africa. (In Van den Berg, J. \& Uys, V.M., eds. Proceedings of the final Workshop of the Southern African Stem Borer Management Programme, $13^{\text {th }}$ Congress of the Entomological Society of southern Africa, Pietermaritzburg. p. 13-16).

Warui, C.M. \& Kuria, J.N. 1983. Population incidence and the control of maize stalkborers Chilo partellus (Swinh.) and Chilo orichalcociliellus Strand and Sesamia calamistis Hmps. in Coast Province, Kenya. Insect Science and its Application 4: 11-18.

Winters, P., Murgai, R., Sadoulet, E., De Janvry, A. \& Frisvold, G. 1998. Economic and welfare impacts of climate change on developing countries. Environmental and Resource Economics 12: 1-24.

World Bank. 2007. World Development Report 2008: Agriculture for development. World Bank: Washington, DC.

Xiong, W., Conway, D., Jiang, J., Li, Y., Lin, E., Xu, Y., Hui, J. \& Calsamiglia-Mendlewicz, S. 2008. Future cereal production in China: modelling the interaction of climate change, water availability and socio-economic scenarios. The impacts of climate change on Chinese agriculture-Phase II. Final Report, AEA Group, UK.

Zhang, T., Huang, Y. \& Yang, X. 2013. Climate warming over the past three decades has shortened rice growth duration in China and cultivar shifts have further accelerated the process for late rice. Global Change Biology 19: 563-570. 


\section{Egg stage}

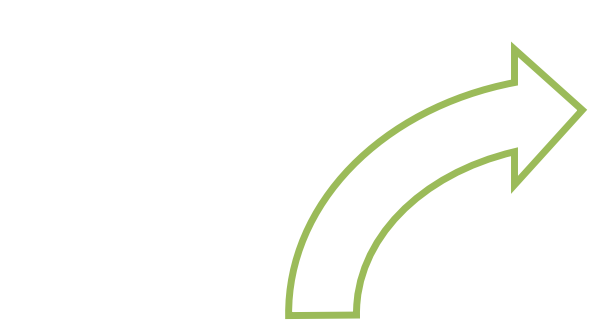

Adult stage
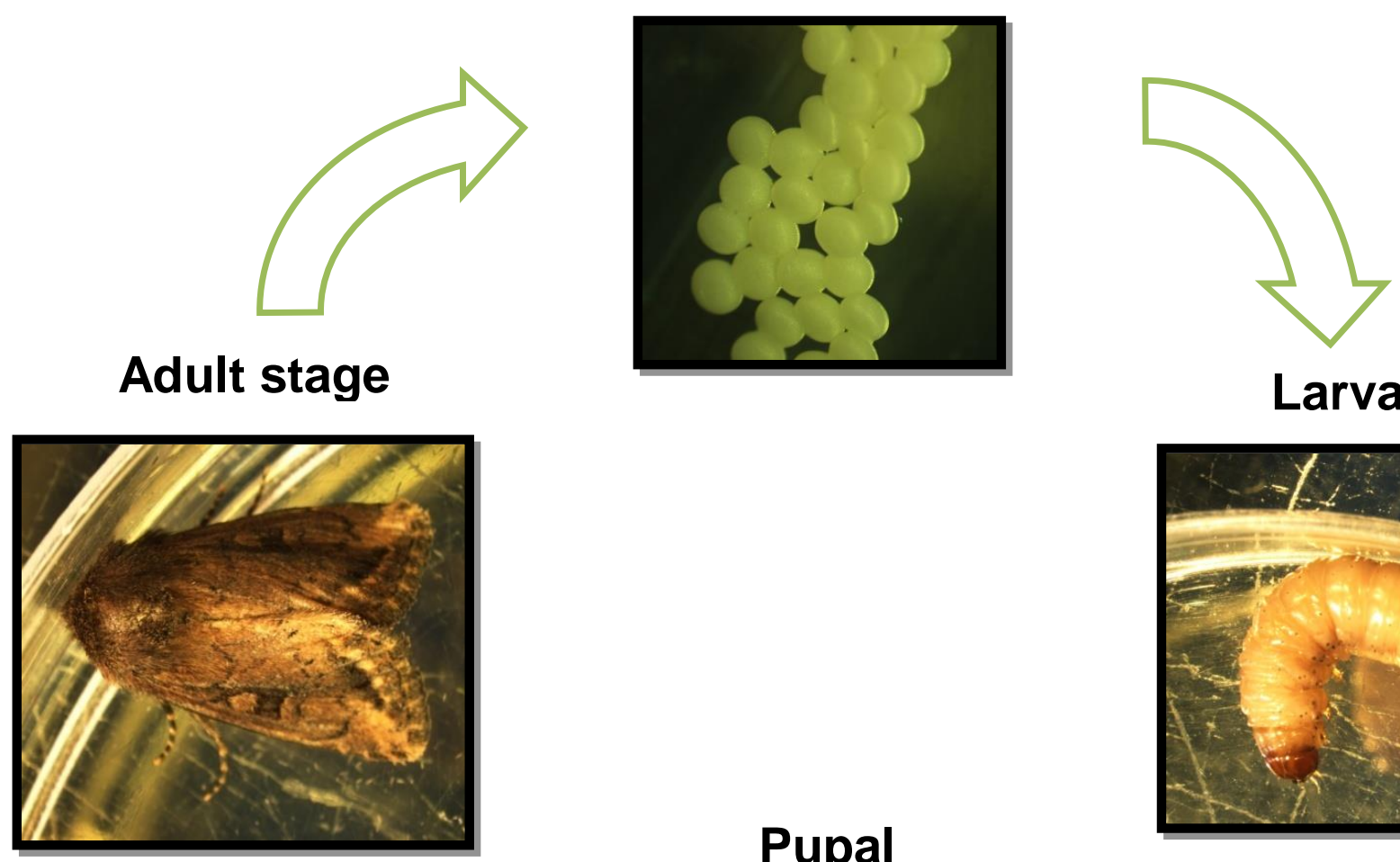

\section{Pupal}
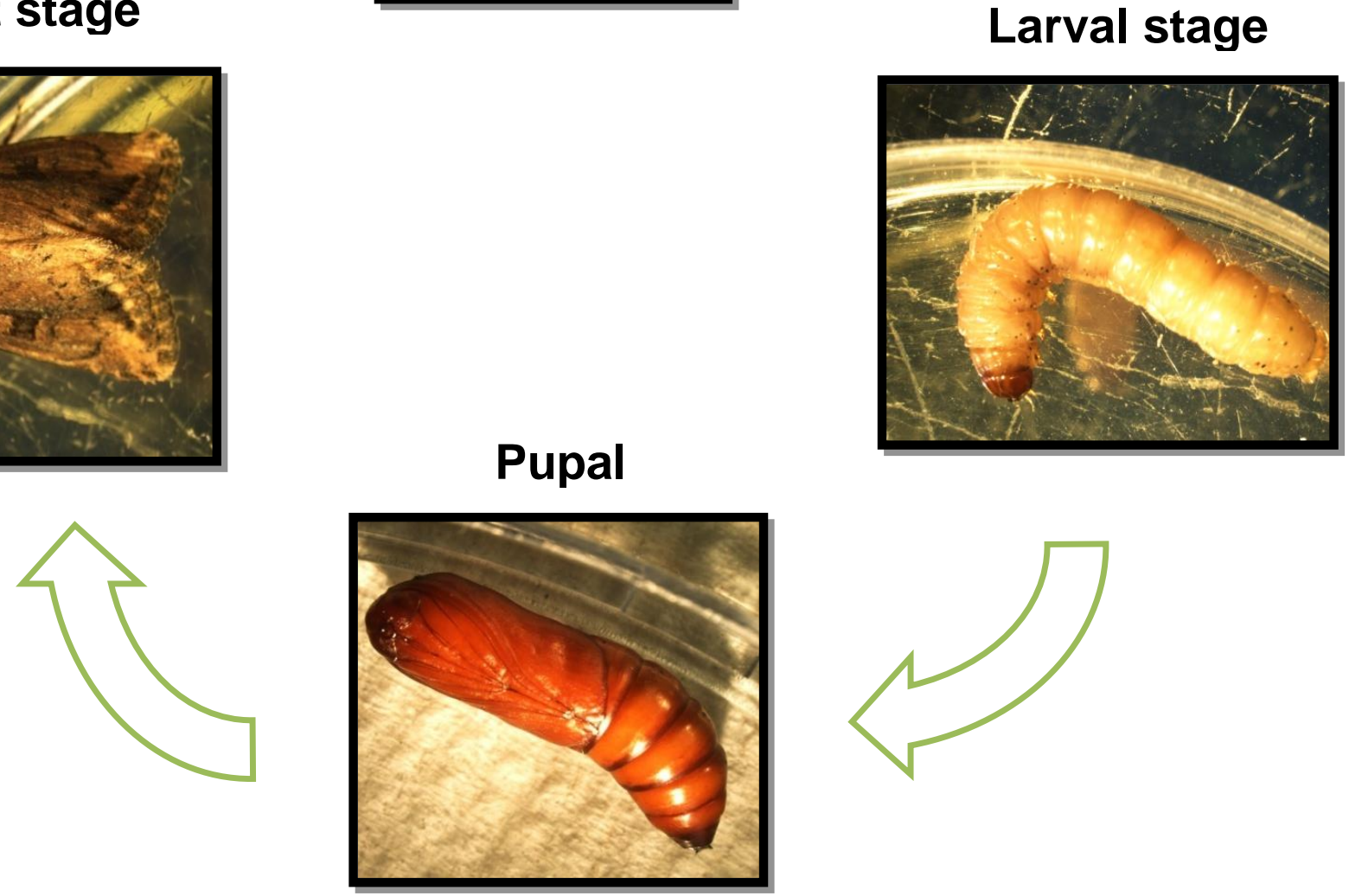

Figure 1.1: Life cycle of Busseola fusca. 

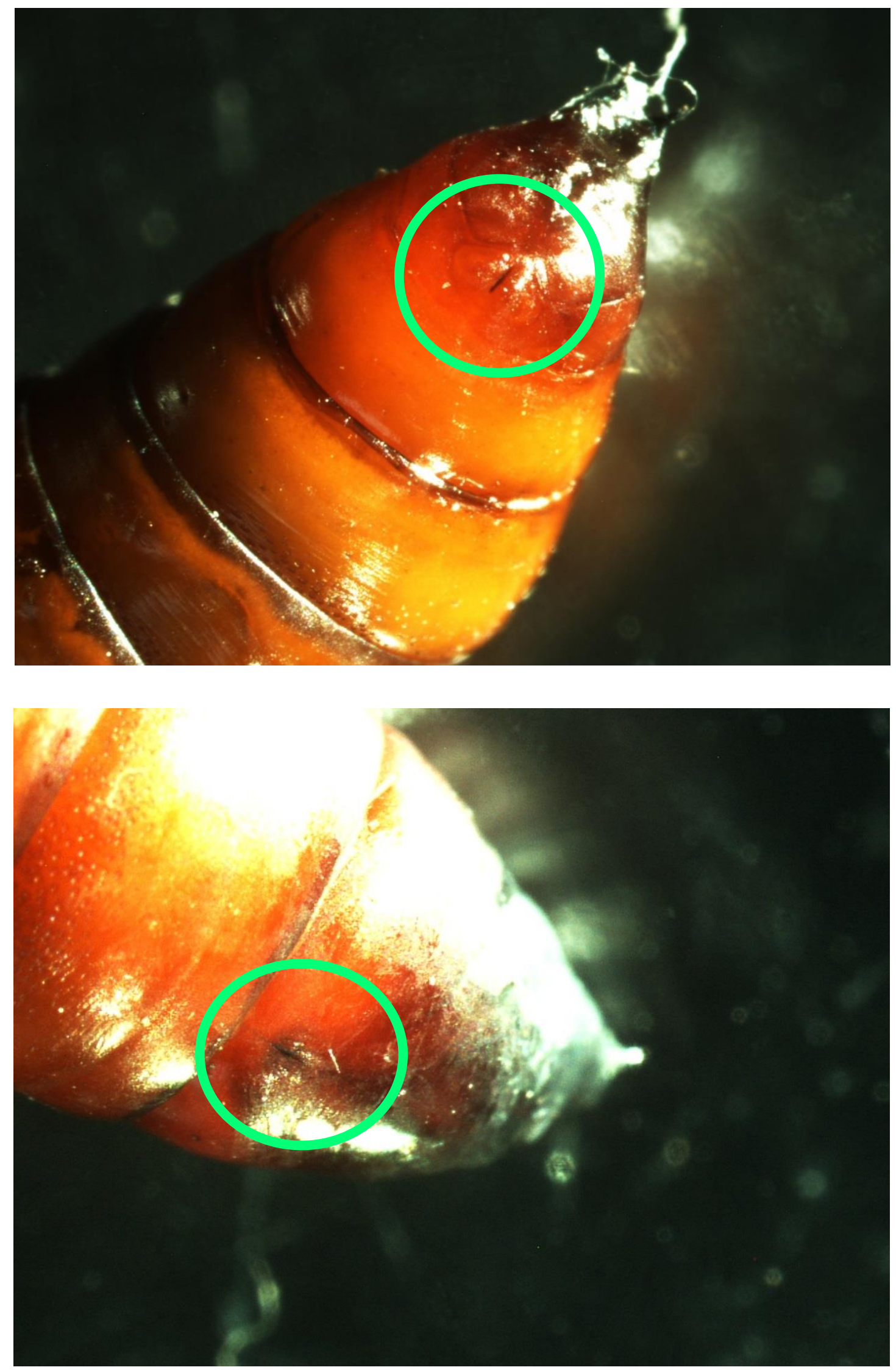

Figure 1.2: The male (top) and female (bottom) pupae of Busseola fusca distinguished by the genital scars on sternum 9 of males and sternum 8 of females. 


\section{CHAPTER 2}

\section{The effect of temperature on the development of Busseola fusca (Lepidoptera: Noctuidae)}

\subsection{Abstract}

The African stem borer, Busseola fusca, is one of the major stem borer pests of maize throughout Africa. Climate change may in future affect the biology of this species. The effect of temperature on the development of $B$. fusca was studied at five different temperature regimes namely $15,18,20,26$ and $30 \pm 1^{\circ} \mathrm{C}$. The number of instars for $B$. fusca was also determined. Development rate was inversely related to temperature within the range 15 - 26 ${ }^{\circ} \mathrm{C}$, but development was reduced at $30^{\circ} \mathrm{C}$. The most favourable temperature as well as the upper threshold temperature for larval development was observed to be between 26 and 30 ${ }^{\circ} \mathrm{C}$. There was a strong positive linear relationship between temperature and the rate of development of the egg, larval and pupal stages as well as total development. The total development period was 152.6 to 52.6 days, respectively, at $15^{\circ} \mathrm{C}$, and $26-30{ }^{\circ} \mathrm{C}$. The thermal constants for $B$. fusca were 99.50, 536.48, 246.25 and $893.66{ }^{\circ} \mathrm{D}$ and lower temperature thresholds was $10.36,8.14,8.99$ and $8.84{ }^{\circ} \mathrm{C}$, for completion of the egg, larval, pupal, and egg-to-adult stages, respectively. The number of larval instars was determined by using head capsule widths that ranged from 0.31 - $2.68 \mathrm{~mm}$. Overlapping occurred from instar 4 to 6 . No distinction could be made between instars 7 and 8 in terms of head capsule width. All successive instars, except for instar eight, increased in size according to Dyar's ratio.

Key words: Busseola fusca, degree-days, development, head capsule widths, temperature 


\subsection{Introduction}

\subsubsection{The effect of temperature on insect development}

Information on insect pest development under different environmental conditions is vital for forecasting, management and risk analysis (Calvo \& Molina, 2005). Pest management is improved by knowledge of the life stages that cause damage, and an understanding of the conditions that slow or accelerate development (Wilson \& Barnett, 1983; Higley \& Peterson, 1994; Waldstein \& Reissig, 2001).

Temperature plays an important role in the development and growth rates of an insect, the duration of its life cycle and survival (Roy et al., 2003). Development occurs within a specific temperature range and is best performed at an optimum temperature. Development rate decreases as the temperature decreases or deviates from the optimum (Begon et al., 2006). Temperature can also affect the physiological traits of insects by causing extra moults and larval stages (Ali \& Gaylor, 1992). Other physiological effects of insects that can also be affected are for example change in body-size, metabolic rates, water relations and feeding habits (Speight et al., 2008).

Making use of studies at constant temperature can provide a basis for prediction of phenological and seasonal development of insects in the natural environment (Mironidis, 2014). However, temperature in the natural environment fluctuates and will affect the lifetime parameters of insects differently compared to constant temperatures. Determining development under constant temperature can, however, provide information on pest population dynamics and accurate scheduling of control techniques of pests (McFarland et al., 1992; Shanower et al., 1993).

\subsubsection{Larval development of Busseola fusca (life cycle)}

Busseola fusca (Lepidoptera: Noctuidae) is oligophagous (Le Ru et al., 2006a, b; Ong'amo et al., 2006; Ndemah et al., 2007), which implies it feeds on a limited number of plant species (Bernays \& Chapman, 1994). Duration of egg development of $B$. fusca is approximately 5 - 6 days depending on temperature. The eggs are yellow and turn black before hatching (black head stage). After emergence, first instar larvae disperse over the leaves to settle on their host plants before they start to feed on the leaves or whorls. Most 
larvae up to the $4^{\text {th }}$ instar will feed in the whorl part of the plant, thereafter moving to the stems (Van Rensburg et al., 1987; Harris \& Nwanze, 1992). Once there, they will feed for about 3 - 5 weeks in the stems and maize ears producing tunnels before entering the pupal stage (Harris \& Nwanze, 1992; Onyango \& Ochieng'-Odero, 1994; Ratnadass et al., 2001). The larval stage is about 24 - 54 days long depending on the temperature (Calatayud et al., 2007).

The duration of the pupal stage is about 9 - 14 days, depending on the temperature (Harris \& Nwanze, 1992; Onyango \& Ochieng'-Odero, 1994; Ratnadass et al., 2001). The life cycle of B. fusca is completed within $7-8$ weeks if the conditions are in their favour (Harris \& Nwanze, 1992). Not all of the larvae pupate; some of them enter diapause which normally happens during winter time when the environment is dry and cold (Kfir, 1991; Kfir et al., 2002).

\subsubsection{Geographical distribution of Busseola fusca}

Busseola fusca is an indigenous pest species in sub-Saharan Africa (Mohyuddin \& Greathead, 1970; Kfir et al., 2002; Le Ru 2006a, b). They attack grain crops (Harris, 1989) and compared to other stem borer species, normally dominates in the high altitude regions (Van Rensburg \& Bate, 1987). Even though it appears as if B. fusca occurs only at high altitudes, reports have shown that they also occur at low attitudes in East Africa (Calatayud et al., 2014) and Zimbabwe (Sithole, 1989). These species are also found in the cooler ecozones of East and southern Africa, in mid-altitude areas and the highlands (Kfir et al., 2002).

Although $B$. fusca is an important pest in Africa, its pest status varies among different regions. In East and southern Africa, $B$. fusca has been found at higher altitudes $(>600 \mathrm{~m})$ (Nye, 1960; Sithole, 1989), but in West Africa, it has been found from sea level to $>2000 \mathrm{~m}$ (Tams \& Bowden, 1953), as well as in the dry savannah zone (Harris, 1962). In South Africa and other African countries, B. fusca have been found at elevations $900 \mathrm{~m}$ above sea level, at lower altitudes (Sithole, 1989; Kfir, 1998), at coastal regions (Van Rensburg, 1997; Waladde et al., 2001), and in the mountains $2131 \mathrm{~m}$ a.s.I. in Lesotho (Ebenebe et al., 1999). In Eritrea, B. fusca mostly occur at altitudes higher than 1500 m (Haile \& Hofsvang, 2001). 


\subsubsection{Climate Change}

Climate change has an impact on environmental conditions such as temperature and precipitation that may lead to extreme events, which may have an effect on the environment and the organisms living in it (IPCC, 2007). Determining the effect of temperature on development of insects will help to predict the life cycle duration and the timing when seasonal emergence occurs as changes in climate occurs (Angilletta \& Dunham, 2003; Kingsolver \& Huey, 2008). Climate determines the distribution and abundance of most insect species (Sutherst, 2000). Their habitats and survival strategies are dependent on the local weather conditions. Since insects are ectotherms and their body temperature varies with the environmental temperature, changes in temperature will have an effect on insects (Harrington et al., 2001; Speight et al., 2008).

\subsubsection{Head capsules}

Determination of larval instars can provide valuable information in pest management (Daly, 1985) providing basic information for the development of morphometric and ecological studies (Williams \& McDonald, 1982; Fischbacher, 1996). The head capsules of larvae are sclerotised (Anderson, 2003), and does not grow or expand during each larval stage. Therefore, the width of head capsule is an important parameter in identifying larval stages (Daly, 1985) and has been used for many lepidopteran and coleopteran species (McClellan \& Logan, 1994; Goldson et al., 2001; Hammack et al., 2003). Many mathematical models have been used to determine the different instars of insects. One of the best known models for distinguishing between instar stages is the Dyar's rule (Gaines \& Campbell, 1935). This model explains that the head capsule of an instar stays more or less constant during one instar stage but increases with every moult. Other statistical methods assume that the head capsules widths are normally distributed for each instar and the peaks indicate each instar (Sokal \& Rohlf, 1995; Panzavolta, 2007). Knowledge regarding pest population age and phenology contribute to improved timing of spray applications aimed at certain instars as well as explaining possible treatment failures (McClellan \& Logan, 1994).

\subsubsection{Objectives}

The objectives of this study were to assess the development rate of $B$. fusca at different constant temperatures, to determine the number of degree-days $\left({ }^{\circ} \mathrm{D}\right)$ required for each stage 
to complete development as well as for overall egg-to-adult development, and to determine the number of larval instars by measuring larval head capsule widths and to develop criteria to determine the specific instar of $B$. fusca.

\subsection{Materials and Methods}

\subsubsection{Busseola fusca stock colony}

Maize stem borer larvae were collected from maize fields $\left(F_{0}\right)$ in the North-West province at

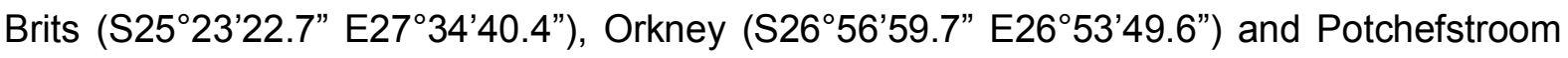

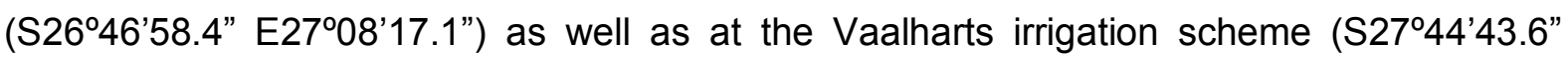
E244ㄱ'02.5") (Northern Cape province). These larvae were reared in plastic containers (40 x $20 \times 15 \mathrm{~cm}$ ) with aerated lids on conventional (non-Bt) maize stems which were replaced at four day intervals. They were kept in a rearing room at $26 \pm 1{ }^{\circ} \mathrm{C}, 70 \% \mathrm{RH}$ and $14 \mathrm{~L}: 10 \mathrm{D}$ photoperiod until pupation. Male and female pupae were separated and kept individually in small plastic bottles (52 $\mathrm{mm}$ high and $30 \mathrm{~mm}$ in diameter) in the same rearing room as the larvae. Pupae were observed daily until the moths emerge.

After emergence of the moths, single male-female pairs were confined to oviposition chambers in a rearing room at $26 \pm 1{ }^{\circ} \mathrm{C}, 70 \pm 10 \% \mathrm{RH}$ and a 14L: 10D photoperiod. The chambers and method used are according to Kruger et al. (2012). A plastic bottle $(22 \mathrm{~cm}$ high and $10 \mathrm{~cm}$ in diameter) was cut open at the top (Fig. 2.1a). The bottle was filled with crusher stones up to a height of $5 \mathrm{~cm}$. One thick maize stem (25-30 mm diameter) and 18 $\mathrm{cm}$ in length with bases of leaves intact was placed in an upright position in the bottle. Stems were inserted $3-4 \mathrm{~cm}$ into the crusher stones to keep the maize stems upright. Water was added up to a level three-quarter of the height of the stones to provide humidity and to keep the stems fresh. The containers were covered with a fine gauze mesh to prevent escape of moths. The stems were observed daily for egg batches and replaced every second day.

\subsubsection{Temperature-dependent egg development}

The egg batches from the stock colony were removed from maize plants within 12 hours of oviposition. They were collected by cutting off the piece of leaf sheath to which the egg batches were attached. About 50 eggs were placed in a small plastic container (52 mm high and $30 \mathrm{~mm}$ in diameter) with a steel mesh infused lid. Thereafter, these plastic containers 
were kept in a glass desiccator $(150 \mathrm{~mm}$ ) in which $\mathrm{RH}$ was maintained at $70 \pm 10 \%$ using a potassium hydroxide solution according to the method of Solomon (1951) (Fig. 2.1b). The desiccators were kept at the $15,18,20,26$ and $30^{\circ} \pm 1{ }^{\circ} \mathrm{C}$ in incubators with a 14L: 10D photoperiod. The temperature and $\mathrm{RH}$ in each desiccator was recorded at 30-minute intervals using iButtons ${ }^{\circledR}$ from Coldchain Thermo Dynamics (Fairbridge technologies) as seen in figure 2.2. The eggs were checked daily until they hatched. The number of days for hatching was recorded until five days after the first larvae hatched.

\subsubsection{Temperature-dependent larval and pupal development}

Eggs were collected from moths kept at $26 \pm 1{ }^{\circ} \mathrm{C}, 70 \pm 10 \% \mathrm{RH}$ and a 14L: 10D photoperiod and transferred into small plastic containers (52 mm high $\times 30 \mathrm{~mm}$ in diameter) with a steel mesh infused lid and placed into a glass desiccator $(150 \mathrm{~mm})$ in which $\mathrm{RH}$ was maintained at $70 \pm 10 \%$ using a potassium hydroxide solution according to the method of Solomon (1951). The desiccators were kept under the same conditions as the abovementioned moths were kept. After hatching, fifteen neonate larvae $\left(F_{1}\right)$ were placed on the whorl of a maize seedling in a plastic test tube (115 mm high $\times 29 \mathrm{~mm}$ in diameter) closed with a steel mesh infused lid (Fig. 2.1c). Larval and pupal development was studied under the same conditions of constant temperature and photoperiod as for the eggs in incubators. There were 15 - 20 test tubes containing 15 larvae each per temperature regime. A piece of filter paper $\left(4 \mathrm{~cm}^{2}\right)$ was placed on the bottom of each test tube to avoid excessive wetness inside the test tube. The test tubes were cleaned daily.

The whorls were checked daily for head capsules and exuviae (shed cuticles). Head capsule and exuviae found were removed to avoid confusion. On moulting to the second instar, larvae were transferred individually to a test tube containing a piece of maize plant consisting of compact unfolded leaves above the growing tip (Fig. 2.3). Daily observations of the larvae were made and moulting as well as survival was recorded. Food was replaced every second day. From fifth instar onwards larvae were fed with a piece of maize stem cut from the base of the whorl. Later instar larvae were fed with stem pieces of older plants (Fig. 2.3 and 2.4). To provide for checking of larvae inside the stem, stems were cut longitudinally and kept together with an elastic band (Fig. 2.5). The temperature and $\mathrm{RH}$ in the maize stem at each temperature regime was recorded at 30 -minute intervals using iButtons ${ }^{\circledR}$ from Coldchain Thermo Dynamics (Fairbridge technologies) as seen in figure 2.2. 
When pupation occurred, the test tube was cleaned and the pupa was transferred back into the tube. Thereafter, it was placed in a plastic container $(37.7 \times 26.8 \times 19.9 \mathrm{~cm})$ enclosed with a steel mesh infused lid containing water in a small bowl to keep $\mathrm{RH}$ at a level of $75 \pm$ $10 \%$ at the respective temperatures (Fig. 2.1d). Pupae were checked daily until the emergence of the moths and the number of days to emergence was recorded. The temperature and $\mathrm{RH}$ in the container at each temperature regime was recorded at 30-minute intervals using iButtons ${ }^{\circledR}$ from Coldchain Thermo Dynamics (Fairbridge technologies) (Fig. 2.2).

\subsubsection{Number of instars}

First instar larvae were collected within 24 hours of hatching from small plastic containers in a glass desiccator which was kept at $26 \pm 1{ }^{\circ} \mathrm{C}$ and 14L: 10D (see 2.3.3). These larvae were reared individually in plastic test tubes $(115 \mathrm{~mm}$ high $\times 29 \mathrm{~mm}$ in diameter) closed with a steel mesh infused lid. After moulting, thirty larvae of each consecutive instar were fixed in $70 \%$ ethanol. Head capsules were measured under a stereo microscope (Nikon SMZ 1500) equipped with a camera and the NIS-Elements D 3.1, Microscope Imaging Software. The head capsule widths were measured as the distance between the most distant lateral sides of the head capsule margins. 


\subsubsection{Data analysis}

\section{Degree-day model}

The relationship between temperature $(\mathrm{x})$ and development rate $(\mathrm{y})$ was determined by using a simple linear regression analysis. The lower threshold temperature $(t)$ and number of degree-days $(k)$ required to complete development for each of the stages, as well as their standard errors were calculated using the equations of Campbell et al. (1974). The lower threshold temperature was estimated by setting $y=0$ and solving $x$ for the regression equation, $y=a+b x$, where:

$y=1 /$ days

$\mathrm{x}=$ temperature

$\mathrm{a}=$ intercept

$\mathrm{b}=$ slope

the lower temperature threshold: $t=-a / b$

number of degree-days $(\stackrel{\circ}{-D}): k=1 / b$

S.E. of $\left.\mathrm{t}=\overline{\mathrm{y}} / \mathrm{b} \sqrt{\left(s^{2}\right.} / N y^{-2}\right)+[\text { S.E. of } \mathrm{b} / \mathrm{b}]^{2}$

S.E. of $k=($ S.E. of $b) / b^{2}$

The mean degree-days ( $(-D)$ for the development of the egg, larval and pupal stage was estimated using the equation of Jackson \& Elliot (1988): ${ }^{\circ} D=T\left(c-T_{\min }\right)$, where $T$ is the number of days taken to complete development at a constant temperature (c) and $T_{\min }$ is the minimum temperature for development. The thermal constant was used and the mean number of ${ }^{\circ} D$ required for development of each life stage at the set constant temperatures were compared.

The effect of temperature on development was analysed by means of one-way ANOVA using STATISTICA 12 (Statsoft, Inc., 2013), followed by Tukey's HSD test ( $P=0.05$ ). 


\section{Head capsule width}

The number of instars was reported by means of frequency distribution of head capsule width and ranges were assigned to individual instars based on measured larval instar head capsule width. The possibility of assigning specimens to instars by Dyar's rule (Dyar, 1890) as [postmoult size/premoult size (moult increment) = constant], was determined. Linear regression analysis was used to establish relationships between temperature and growth ratios.

\subsection{Results}

Busseola fusca completed development at all temperatures between 15 and $30{ }^{\circ} \mathrm{C}$ (Table 2.1). Development time for eggs and larval instars one to five was inversely related to temperature from 15 to $26{ }^{\circ} \mathrm{C}$, with development for all life stages significantly delayed at 15 ${ }^{\circ} \mathrm{C}$. Incubation time for eggs significantly decreased from 22.5 days at $15{ }^{\circ} \mathrm{C}$ to 5.9 days at $30^{\circ} \mathrm{C}\left(\mathrm{F}_{4,102}=938.3 ; \mathrm{P}<0.001\right)$. Busseola fusca larvae completed their life cycle the slowest at $15^{\circ} \mathrm{C}$ (90.2 days) and the fastest at $26^{\circ} \mathrm{C}$ (31.2 days) (Table 2.1). Development time was longer at $30{ }^{\circ} \mathrm{C}$, although not significantly different from $26^{\circ} \mathrm{C}$. Total development of $B$. fusca took 152.6 days at $15^{\circ} \mathrm{C}$ and 52.6 days at 26 and $30^{\circ} \mathrm{C}$. In general, development time decreased as temperature increased. However, at $30{ }^{\circ} \mathrm{C}$, duration of development for fifth instar larvae onwards, as well as total larval development time increased (Table 2.1). The upper threshold temperature for larval development is therefore between 26 and $30{ }^{\circ} \mathrm{C}$.

All larvae went through six larval instars, 70 of these went through seven instars and four larvae reached an eight instar before pupation. One larva moulted within one day from fifth to sixth instar at $30{ }^{\circ} \mathrm{C}$ and several larvae took two days to complete an instar at 26 and $30^{\circ} \mathrm{C}$ for consecutive instars from the second to sixth instars and from the second to fourth instars, respectively. The longest development time spent in an instar was 32 days at $15^{\circ} \mathrm{C}$ (Table 2.1).

There was a significant difference in development time at $15,18,20$ and $26^{\circ} \mathrm{C}$ for first to fifth instar larvae [(first instar: $\left.F_{4,125}=271.2 ; P<0.001\right)$, (second instar: $F_{4,125}=133.5 ; P<0.001$ ), (third instar: $F_{4,125}=203.4 ; P<0.001$ ), (fourth instar: $F_{4,125}=122.6 ; P<0.001$ ) and (fifth instar: $\left.\left.F_{4,125}=102.1 ; P<0.001\right)\right]$. Development time was also similar for instars one, three, four, five, six and seven at 26 and $30^{\circ} \mathrm{C}$ (Table 2.1). Development time of second instar larvae differed significantly between all temperatures evaluated in this study (Table 2.1). 
Development was significantly longer at $15{ }^{\circ} \mathrm{C}$ compared to the other temperatures. Sixth instar larvae developed at a similar rate at 18 and $20^{\circ} \mathrm{C}$, which was significantly longer than at 26 and $30{ }^{\circ} \mathrm{C}\left(\mathrm{F}_{4,125}=23.7 ; \mathrm{P}<0.001\right)$. Although sixth instar larvae developed slower at $30{ }^{\circ} \mathrm{C}$ compared to $26^{\circ} \mathrm{C}$, this difference in development time was not significant (Table 2.1). Development time of sixth instar larvae accounted for 22 - $32 \%$ of the total larval development period and $14-19 \%$ of the total development period. The duration of development time for larval instar six and onwards (instar 6 to 8, where applicable), accounted for $48-59 \%$ of the total- and $80-96 \%$ of the larval development period, respectively.

Larval survival was low at all temperatures evaluated with the highest percentage survival of $25 \%$, at $20{ }^{\circ} \mathrm{C}$ (Table 2.1). It was lower at 15,18 and $30{ }^{\circ} \mathrm{C}$ compared to 20 and $26{ }^{\circ} \mathrm{C}$. Almost no larvae (3.3\%) survived and completed their development at $15^{\circ} \mathrm{C}$. The optimum temperature for $B$. fusca development, in terms of survival and development is therefore between 20 and $26{ }^{\circ} \mathrm{C}$.

The relationship between temperature and developmental rate of $B$. fusca was linear between 15 and $26^{\circ} \mathrm{C}$ and more rapid development was observed with increasing temperatures (Fig. 2.6 and Fig. 2.7). The highest rearing temperature of $30^{\circ} \mathrm{C}$ was excluded from the least square linear regression analyses, since it did not fit the linear portion of the graph. The correlation ( $r$-value) between temperature and development rate ranged between 0.93 and 0.96 for eggs, total larval development, pupae and egg-to-adult development (Table 2.2). Linear regression equations describing these relationships and estimates of the lower temperature threshold $(\mathrm{t})$ and the number of degree-days $\left({ }^{\circ} \mathrm{D}\right)$ for each life stage are summarized in table 2.2. Busseola fusca required a thermal constant (k) of 99.5, 536.5, 246.3 and $893.7^{\circ} \mathrm{D}$ for completion of the egg, larval, pupal and egg-to-adult development, respectively (Table 2.2 ), which is comparable to the mean degree-days estimated as determined in this study (Table 2.3). The number of degree-days estimated to complete the life cycle of $B$. fusca at $15,18,20$ and $26^{\circ} \mathrm{C}$ were also similar (Table 2.3). Based on linear regression analysis of development rate at all temperatures, a minimum temperature threshold between 8 and $11^{\circ} \mathrm{C}$ was estimated depending on the development stage. The minimum threshold temperature for the larval stage was lower than for the egg stage. Eggs will therefore hatch at temperatures which is also suitable for larval development.

Head capsule widths of $B$. fusca ranged from $0.31 \mathrm{~mm}$ to $2.68 \mathrm{~mm}$ (Fig. 2.8). The frequency distribution of head capsule widths of instar 1,2 and 3 was absolute with no overlapping. The distribution of head capsule widths showed overlapping from the fourth instar onwards. 
No distinction could be made between instars 7 and 8 in terms of head capsule width. All successive instars, except for instar eight, increased in size according to Dyar's ratio (Table 2.4). The head capsule width distribution of $B$. fusca was also confirmed by linear regression analysis indicating a relationship between larval instars and (log head capsule width) with the r-value of 0.975 . Instar $8 \mathrm{did}$, however, not fit the linearity and the capsule widths overlapped with those of instar 6 and 7 larvae (Fig. 2.9). The head capsules of each instar (1 - 7) are shown in figure 2.10.

\subsection{Discussion}

Insects have a limited temperature range within which they can develop. There is an optimal temperature point where individual development occurs at its best, and the upper and lower lethal points which may lead to the death of the insect. Considering development time and survival in this study, the most favourable temperature range for $B$. fusca development was between 26 and $30{ }^{\circ} \mathrm{C}$. Usua (1968) reported a suitable range for $B$. fusca development to be between 20 and $30{ }^{\circ} \mathrm{C}$, with the optimum temperature range between 26 and $30{ }^{\circ} \mathrm{C}$. Results from the current study is in concordance with this suitable range as suggested by Usua, (1968), but supports the optimal temperature range for $B$. fusca development which was also determined by Khadioli et al. (2014) to be between 25 and $28^{\circ} \mathrm{C}$.

Busseola fusca eggs, larvae and pupae did develop at a constant temperature of $15{ }^{\circ} \mathrm{C}$, although very slowly and the percentage survival was low compared to higher temperatures. These results differ from those of Usua (1968), who reported that $22{ }^{\circ} \mathrm{C}$ was too cold for development. However, these results are in accordance with Khadioli et al. (2014) who reported development to occur at $22{ }^{\circ} \mathrm{C}$. Usua (1968) also reported temperatures of $32{ }^{\circ} \mathrm{C}$ and above as lethal to $B$. fusca. This was supported by the findings of Khadioli et al. (2014) that no development occurred above $30^{\circ} \mathrm{C}$. During the present study, development was completed at $30{ }^{\circ} \mathrm{C}$, but development rate was not linear with development at lower temperatures. Development was slower at $30^{\circ} \mathrm{C}$ than at $26^{\circ} \mathrm{C}$, indicating that the maximum temperature for development was exceeded. Since mortality of larvae was also high at a constant temperature of 15 and $20^{\circ} \mathrm{C}$, continuous low temperatures, although not extreme, will reduce a population.

Development rate was inversely related to temperature up to $26^{\circ} \mathrm{C}$. Development time of eggs accounted for $11-15 \%$ of the total development period at the respective temperatures Development time of later instar B. fusca larvae (sixth instar onwards) accounted for $80 \%$ 
and more of the total larval development period, regardless of the temperature. Later instar larvae consume more plant material than earlier instars, because they are larger and approach pupation. In many insect species, the last instar of the immature stages needs to ingest large amounts of food to maximise the reproductive potential of the adult (Scriber \& Slansky, 1981). Maize plants are therefore longer exposed to the later and thus more damaging instars of $B$. fusca compared to the less injurious instars.

A recent temperature study on $B$. fusca in Kenya, reported total development from 223.85 62.74 days at $15-28^{\circ} \mathrm{C}$, respectively (Khadioli et al., 2014). The development time at $30^{\circ} \mathrm{C}$ increased to 81.26 days (Khadioli et al., 2014). The Kenyan B. fusca population therefore had a longer development time than the South African population used in the present study. Photoperiod did, however, differ with a 12L: 12D photoperiod used in Kenya compared to 14L: 10D in South Africa. The incubation period of eggs decreased with increasing relative humidity. At $80 \%$ and higher the incubation period was $5-6$ days to hatching, at $70 \% \mathrm{RH}, 6$ - 7 days and $60 \% \mathrm{RH}, 7$ - 8 days (Usua, 1968). The difference in relative humidity used in the two studies compared, may therefore also account for some of the observed differences. Unnithan (1987) also reported temperature-dependent development of $B$. fusca from Kenya where larval to adult development time was an average of 40.8 days and the egg stage was between 5 - 6 days at $23-27^{\circ} \mathrm{C}$. Thus, complete development was between $45.8-46.8$ days.

Development at constant temperatures was also studied for other lepidopteran stem borer species with similar temperature thresholds as with $B$. fusca during this study. The spotted stem borer, Chilo partellus (Lepidoptera: Crambidae), was studied under three temperature regimes, namely 22,26 and $30{ }^{\circ} \mathrm{C}$ using different levels of $\mathrm{RH}$ of 40,60 and $80 \%$, and its development was found to be significantly affected by temperature and $\mathrm{RH}$ (Tamiru et al., 2012). The mean number of days to complete its life cycle was 70.2 days at $22{ }^{\circ} \mathrm{C}$ and $80 \%$ $\mathrm{RH}$ and 26.5 days at $30{ }^{\circ} \mathrm{C}$ and $40 \% \mathrm{RH}$. The most suitable temperature for development of C. partellus was reported to be between $26-30{ }^{\circ} \mathrm{C}$ (Tamiru et al., 2012). Larval development time of Sesamia nonagrioides (Lepidoptera: Noctuidae) significantly declined as temperature increased between $14-25^{\circ} \mathrm{C}$ (Andreadis et al., 2013). The upper and lower development threshold temperatures ranged between $31.2-36.2^{\circ} \mathrm{C}$ and $7.0-10.3{ }^{\circ} \mathrm{C}$, respectively and the optimum temperature was reported between $28.1-30.3^{\circ} \mathrm{C}$ (Andreadis et al., 2013). Complete development rate of Helicoverpa armiga (Lepidoptera: Noctuidae) decreased from 57.2 - 23.4 days as temperature increased from 17.5 to $30.0^{\circ} \mathrm{C}$ (Mironidis \& Savopoulou-Soultani, 2008). Development for this species was not completed at $15{ }^{\circ} \mathrm{C}$, 
therefore having a higher, lower temperature threshold than $15^{\circ} \mathrm{C}$ (Mironidis \& SavopoulouSoultani, 2008).

The larval stage of $B$. fusca reared on maize stems at temperatures between 26 and $30{ }^{\circ} \mathrm{C}$ in the current study lasted on average 32.1 and 33.4 days, respectively. However, Ratnadass et al. (2001) reported 50 days at $25 \pm 1{ }^{\circ} \mathrm{C}$ and Onyango \& Ochieng'-Odero (1994) an average of 46 days at temperatures between 25 and $30^{\circ} \mathrm{C}$. Khadioli et al. (2014) reported the larval stage duration to range from 50.7 at $25^{\circ} \mathrm{C}$ to 58.1 at $30{ }^{\circ} \mathrm{C}$. All these populations were from temperate regions and were reared on artificial diet compared to the South African B. fusca population of this study which originated from an area with sub-zero night temperatures during winter. The fact that larvae in this study were reared on maize tissue and not artificial diet may also have contributed to the observed differences. Development time of the eggs and pupae was similar when compared to the abovementioned studies. The average development time of $B$. fusca eggs from this study was 6.5 and 5.9 days and pupal development took 14.0 and 13.3 days, respectively at 26 and $30{ }^{\circ} \mathrm{C}$. Eggs of $B$. fusca developed between five to six days at $23-27^{\circ} \mathrm{C}$ (Unnithan, 1987). Onyango \& Ochieng'-Odero (1994) reported 6 and 14 days respectively, for egg and pupal development at $26-30^{\circ} \mathrm{C}$. A recent study where $B$. fusca was also fed on an artificial diet reported the average development time for eggs and pupae as 7.2 and 14.7 at $25^{\circ} \mathrm{C}$ and 6.5 and 16.6 at $30^{\circ} \mathrm{C}$ (Khadioli et al., 2014). The diet of larvae does, therefore not seem to affect development time of the pupae.

Although relative humidity is often reported in temperature-dependent development studies for insects, it reflects only the relative humidity inside of the incubator or rearing room. The actual temperature inside the container or exact place of rearing of the insect is often not recorded as was done in the present study. In this study, the relative humidity inside stems where the stem borer larvae were reared was always $100 \%$. The possibility of desiccation where larvae occur inside stems under field conditions where low humidity may prevail is therefore not possible, except during the natural dry off-season phase of the crop or towards the end of the season. Relative humidity is an important factor influencing the biology and development of insects (Gullan \& Cranston, 2005). For example, low relative humidity can cause development rate to slow down (Gullan \& Cranston, 2005). However, this will not be applicable to $B$. fusca occurring and developing in maize stems where $100 \%$ humidity occurs during the active vegetative and reproductive growth stages of the plants.

The development rate of $B$. fusca was strongly related to temperature. The number of degree-days needed by $B$. fusca to complete the different life stages was $99.58,543.58$, 
253.18 and $899.92^{\circ} \mathrm{D}$, and the lower temperature thresholds were $10.36,8.99,8.14$ and $8.84{ }^{\circ} \mathrm{C}$, respectively, for eggs, larvae, pupae and egg-to-adult. Survival of larvae was, however, still low at a temperature six degrees higher than the lower threshold temperature determined. This indicates that the optimum temperature for development should be well above the lower threshold temperature.

The thermal constants and development thresholds were also determined for other stem borer species. For Eldana saccharina (Lepidoptera: Pyralidae), the degree-days and thermal thresholds for the egg, larval and pupal stages were 119.0, 618.6 and $160 .{ }^{\circ} \mathrm{D}$, above average thresholds of $5.3,10.2$ and $10.7^{\circ} \mathrm{C}$, respectively (Way, 1995). Total development period of Sesamia calamistis (Lepidoptera: Noctuidae), required $700{ }^{\circ} \mathrm{D}$, eggs required 122 ${ }^{\circ} \mathrm{D}$ above a threshold of $9.7^{\circ} \mathrm{C}$, larvae, $383^{\circ} \mathrm{D}$ above $12.2^{\circ} \mathrm{C}$ and pupae $204^{\circ} \mathrm{D}$ above 10.2 ${ }^{\circ} \mathrm{C}$ (Shanower et al., 1993). The degree-days needed for the different development stages of Chilo sacchariphagus (Lepidoptera: Crambidae) are: eggs: $144^{\circ} \mathrm{D}$ above $13.1^{\circ} \mathrm{C}$; larvae: $586^{\circ} \mathrm{D}$ above $12.7^{\circ} \mathrm{C}$; pupae: $172^{\circ} \mathrm{D}$ above $13^{\circ} \mathrm{C}$ and egg-to-adult: $872{ }^{\circ} \mathrm{D}$ (Goebel, 2006). Variation in temperature thresholds is an important determinant in the distribution of insects (Cammell \& Knight, 1992; Marco et al., 1997). If a specific development stage cannot survive a certain temperature, then the distribution of the species is likely to be restricted by the temperature threshold of that stage (Cammell \& Knight, 1992).

The geographical distribution of insect species can be ascribed to their adaptation to thermal conditions and their tolerances for these conditions (Bijlsma \& Loeschcke, 2005; David et al., 2005; Overgaard et al., 2010). High temperatures may cause insects to avoid overheating through shade-seeking, avoidance behaviour, through increased evaporate cooling or biochemical reactions. They can create rapid biochemical protection such as heat shock proteins that will cause cell function to cease after the probability of cell damage (Denlinger \& Lee, 2010; Terblanche, 2013). High temperatures also cause rapid response to hardening (inducible thermo-tolerance) when exposed to stressful conditions where the insect increase its tolerance level (Denlinger et al., 1991; Loeschcke et al., 1997; Dahlgaard et al., 1998). Hardening in terms of high temperatures is more associated with rapid responses to shortterm moderately stressful exposures (Denlinger et al., 1991, Loeschcke et al., 1997; Dahlgaard et al., 1998). When insects are exposed to high temperatures, heat injury may occur depending on its severity. High temperature injury causes disruption of membrane function (Cossins \& Bowler, 1987), changes in the cell microenvironment $(\mathrm{pH})$, perturbation of protein structure, and DNA lesions (Somero, 1995; Feder, 1999). Therefore, these changes affect development, muscular contraction and other processes (Denlinger \& Yocum, 1998). The membrane's responses to temperature cause changes in the 
composition of cellular lipids (Gracey et al., 1996; Somero et al., 1996). Heat shock proteins are a response to stress such as thermal stress (Feder \& Hofmann, 1999). Severe thermal stress can cause perturbation to the protein structure (Feder, 1996, 1999; Feder \& Hofmann, 1999).

In temperate regions, there is a part of the year that is unsuitable for growth and development especially for insects (Nylin \& Gotthard, 1998). Therefore, insects must have survival strategies in order to reach a certain size and development stage before the onset of winter. Consequently, development is time limited for temperate individuals. The time available for development can be estimated through variations in climatic variables such as temperature and photoperiod (Nylin \& Gotthard, 1998).

Insects under cold temperatures below the optimum (sub-lethal and lethal temperatures) have more responses than at high temperatures (Lee, 1989). These responses to cold temperatures are cessation of activity and feeding, reduction in neuromuscular responses, chill coma or mortality (Chown \& Nicolson, 2004), as well as responses to anti-freezing and to prepare itself against freezing temperatures (Lee, 1989). The rate at which insects cool, has an effect on their ability to survive low temperatures (Ramlov, 2000; Sinclair, 2001). Cold hardening is a slow process that gradually increases the insect's tolerance to cold temperatures increasing better survival in the nature (Denlinger \& Lee, 1998; Kelty \& Lee, 2001). Insects can survive extreme low-temperature environments through tolerating or avoiding freezing strategies that increases the probability to enter diapause at higher latitudes (Bale, 2002; Lee \& Denlinger, 2010). The strategy used by B. fusca for survival during cold temperatures is to enter into diapause during the cold winter period (Kfir, 1991; Kfir et al., 2002). During diapause, no activity occurs and this leads to profound drop in metabolic rate which is linked to an increase in cold hardiness (Bale et al., 2002). Therefore, $B$. fusca can survive the cold winters of the South African maize producing region that often reach sub-zero temperatures at night. The thermo-biological scale given by Vannier (1994) shows that at temperature above and below the optimum, insects experience initially either heat or cold stupor, thereafter leading to either heat or chill coma, respectively, and ultimately death.

Temperature also affects the physiological traits of an insect. The body temperature of an insect affects their behaviour and physiology such as locomotion, immune function, sensory input, foraging ability, courtship and feeding and growth tempo (Angilletta et al., 2002). Therefore, temperature determines the fitness of an insect (Akiyama \& Nishida, 2013). Environmental conditions may play a role in the number of instars for certain insect species. 
It may be more or less than the usual number of instars for a target species (Malusi \& Okuku personal observation, 2013).

The maximum number of larval instars for $B$. fusca found during this study was eight. The head widths of larvae ranged from $0.31 \mathrm{~mm}$ in the first instar to $2.68 \mathrm{~mm}$ in the last larval instar prior to pupation. It is a known phenomenon that $B$. fusca usually has six instars, but the species are not restricted to six only. Eight instars were also reported by Unnithan (1987), Smithers (1960) and Calatayud et al. (2007). The head capsule widths measured in the current study for instars one to six ranged from $0.31 \mathrm{~mm}$ to $2.40 \mathrm{~mm}$, and differed from the head capsule widths range of $0.32-2.2 \mathrm{~mm}$ for the respective instars reported by Unnithan (1987). Larvae kept for prolonged periods at 15 and $18{ }^{\circ} \mathrm{C}$ reached up to 10 larval instars determined by moulting only (J. Glatz, personal observation). Eight instars were also reported for the sugercane stem borer, C. sacchariphagus, at temperatures from $17-35^{\circ} \mathrm{C}$ (Goebel, 2006). For E. saccharina, five to seven instars were reported (Atkinson, 1980; Way, 1995; Bonato \& Schulthess, 1998).

Some insects can exhibit catch-up growth when certain environmental conditions cause a delay in their development. Supernumerary moults by the African armyworm, $S$. exempta (Lepidoptera: Noctuidae) were needed to reach the same final body size when reared on poor quality grasses (Yarro, 1985). According to Stockoff (1993), female gypsy moths (Lymantria dispar, Lepidoptera: Lymantriidae) went through an extra larval instar to store more nutrients for oogenesis. Sesamia nonagrioides increases its weight during extra moults prior to diapause and during short day photoperiods of 10L: 14D (Eizaguirre et al., 1994; Gadenne et al., 1997). Larvae moult mainly to increase the size of its mouthparts (Esperk \& Tammaru, 2004). Thus, during moults feeding may be limited that results in a loss of growing time. Growth slows down remarkably before moulting and stops completely when the process starts (Sehnal, 1985).

According to Dyar's rule, a straight line should result if the logarithm of the measurement of a sclerotised body part in different instars is plotted against the instar number, and any deviation from a straight line indicates missing instars (Gullan \& Cranston, 2005). A linear progression therefore exists if the growth ratio is constant between the head capsule widths of each instar for a given species where the ratio ranges between $1.3-1.7$ (Gullan \& Cranston, 2005). The larval instars of $B$. fusca followed Dyar's rule up to the seventh instar, but the head width measurements indicated that there was no difference in head capsule widths of instar seven and eight even though these larvae moulted. 
Malusi \& Okuku (personal observation, 2013) reared B. fusca larvae under optimum environmental conditions $\left(25^{\circ} \mathrm{C}\right.$ and $50-60 \% \mathrm{RH}$ ) on an artificial diet and reported only five instars within its life cycle that was completed at an average of 35 days. Under less favourable conditions such as a sub-optimal temperature or where larvae enter a diapause, additional instars were observed (Malusi \& Okuku, personal observation 2013). Additional moultings were also reported for other lepidopteran species depending on the environmental conditions. An extra moult occurred for Spodoptera exigua (Lepidoptera: Noctuidae) with six instead of five instars at the extreme temperatures of 15 and $34{ }^{\circ} \mathrm{C}$ (Karimi-Malati et al., 2014). The size of these larvae was, however, smaller at $33-34{ }^{\circ} \mathrm{C}$ than at $25^{\circ} \mathrm{C}$. KarimiMalati et al. (2014) speculated that the extra moults may be needed for larvae to reach a critical size.

Insects can modify their responses to temperature effects, a phenomenon known as capacity adaptation. Resistance adaptations can also occur when insects are faced with lethal effects of temperature extremes (Cossins \& Bowler, 1987). However, insects don't exactly adapt to the changes but the responses are mostly a consequence of phenotypic plasticity or flexibility (Pörtner, 2001). Insects can alter the relationship between temperature they experience and their survival probability, as well as the costs of these changes and the similarities and differences between the responses to upper and lower lethal temperatures (Chown \& Nicolson, 2004). Each life history trait has benefits and costs. Increased development time can increase the risk of predation and high growth rates depend on rapid feeding rates (Bernays, 1997). High growth rates are expected to be associated with rise in temperatures but other factors may also play a role. Therefore, time can be a limiting factor leading individual larvae to increase their growth rates and thereby achieve shorter development times but at a cost in final body size when fully grown (Gotthard, 2004).

Insects experiencing changes in environmental temperatures have fluctuations in their metabolism, even when they are inactive. Energy is produced through the metabolism of substrates and a high rate of metabolism contributes to rapid growth rates as long as food resources are abundant (Speight et al., 2008). Metabolic rate of insects has high fluctuations and is affected by environmental (e.g. temperature), developmental, behavioral and evolutionary factors (Waters \& Harrison, 2012). Since energy consumption is low and metabolic rates are slow in cold environments, insects can survive longer without starving under such conditions. The same survival strategy can occur when food resources are scarce (Speight et al., 2008). 
Constant feeding is important to ensure optimal growth and development. The food quality and quantity consumed by insects determine its growth rate, development time, body mass and survival (Slanky \& Scriber, 1985). For larvae, high protein amounts are required for rapid tissue growth (Bernays, 1986; Waldbauer \& Friedman, 1991). Larvae have faster growth rates, and double the consumption and gut capacity of grasshoppers or cockroaches (Bernays, 1986). In this study, higher temperatures caused B. fusca to eat rapidly and grow faster. This will result in more generations per year under favourable environmental conditions. Nitrogen-rich proteins are the major building blocks of tissue. Therefore, young larvae need relatively large amounts of protein in their diets. Many plants have relatively low levels of organic nitrogen in their tissues so insects have developed many ways to increase the levels of protein in their diet (Speight et al., 2008). One protein source utilized by insects is to eat its own exuviae (shed cuticle) (Mira, 2000). This has been observed for B. fusca larvae especially the older larvae (J. Glatz, personal observation). Other chemical components are also important for insects such as carbohydrates that provide the energy (fuel) and fats for fuel storage (Speight et al., 2008).

\subsection{References}

Akiyama, K. \& Nishida, T. 2013. Highly-enhanced larval growth during the cold season mediated by the basking behavior of the butterfly Parnassius citrinarius (Lepidoptera: Papilionidae). Entomological Science 16: 284-290.

Ali, A. \& Gaylor, M.J. 1992. Effects of temperature and larval diet on development of the beet armyworm (Lepidoptera: Noctuidae). Environmental Entomology 21: 780-786.

Andersen, S.O. 2003. Exoskeleton. (In Resh, V.H. \& Carde, R.T., eds. Encyclopaedia of insects. Academic Press: San Diego, CA. p. 387-390).

Andreadis, S.S., Kagkelaris, N.K., Eliopoulos, P.A. \& Savopoulou-Soultani, M. 2013. Temperature-dependent development of Sesamia nonagrioides. Journal of Pest Science 86: 409-417.

Angilletta, M.J. \& Dunham, A.E. 2003. The temperature-size rule in ectotherms: simple evolutionary explanations may not be general. American Naturalist 162: 332-342. 
Angilletta, M.J., Niewiarowski, P.H. \& Navas, C.A. 2002. The evolution of thermal physiology in ectotherms. Journal of Thermal Biology 27: 249-268.

Atkinson, P.R. 1980. On the biology, distribution and natural host-plants of Eldana saccharina Walker (Lepidoptera: Pyralidae). Journal of the Entomological Society of Southern Africa 43: 171-194.

Bale, J.S. 2002. Insects and low temperatures: from molecular biology to distributions and abundance. Philosophical Transactions of the Royal Society of London - Series B:

Biological Sciences 357: 849-862.

Bale, J.S., Masters, G.J., Hodkinson, I.D., Awmack, C., Bezemer, T.M., Brown, V.K., Butterfield, J., Buse, A., Coulson, J.C., Farrar, J., Good, J.E.G., Harrington, R., Hartley, S., Jones, T.H., Lindroth, R.L., Press, M.C., Symrnioudis, I., Watt, A.D. \& Whittaker, J.B. 2002. Herbivory in global climate change research: direct effects of rising temperature on insect herbivores. Global Change Biology 8: 1-16.

Begon, M., Towsend, C.R. \& Harper, J.L. 2006. Ecology: from individuals to ecosystems. $4^{\text {th }}$ ed. Blackwell: Oxford, UK. 738 p.

Bernays, E.A. 1986. Evolutionary contrasts in insects: nutritional advantages of holometabolous development. Physiological Entomology 11: 377-382.

Bernays, E.A. 1997. Feeding by lepidopteran larvae is dangerous. Ecological Entomology 22: 121-123.

Bernays, E.A. \& Chapman, R.F. 1994. Host-plant selection by phytophagous insects. Chapman \& Hall: London, UK. 292 p.

Bijlsma, R. \& Loeschcke, V. 2005. Environmental stress, adaptation and evolution: an overview. Journal of Evolutionary Biology 18: 744-749.

Bonato, O. \& Schulthess, F. 1998. Selecting a character for identifying larval instars of Sesamia calamistis Hampson (Noctuidae) and Eldana saccharina Walker (Pyralidae) in maize. Insect Science and its Application 18: 101-103. 
Calatayud, P.A., Le Ru, B.P., Van den Berg, J. \& Schulthess, F. 2014. Ecology of the African maize stalk borer, Busseola fusca (Lepidoptera: Noctuidae) with special reference to insect-plant interactions. Insects 5: 539-563.

Calatayud, P.A., Guénégo, H., Le Ru, B.P., Silvain, J.F. \& Frérot, B. 2007. Temporal patterns of emergence, calling behaviour and oviposition period of the maize stem borer, Busseola fusca (Fuller) (Lepidoptera: Noctuidae). Annales de la Societe Entomologique de France 43: 63-68.

Calvo, D. \& Molina, J.M. 2005. Developmental rates of the lappet moth Streblote panda Hübner [1820] (Lepidoptera: Lasiocampidae) at constant temperatures. Spanish Journal of Agricultural Research 3: 319-325.

Cammell, M.E. \& Knight, J.D. 1992. Effects of climatic-change on the population dynamics of crop pests. Advances in Ecological Research 22: 117-162.

Campbell, A., Frazer, B.D., Gilbert, N., Gutierrez, A.P. \& Mackauer, M. 1974. Temperature requirements of some aphids and their parasites. Journal of Applied Ecology 11: 431-438.

Chown, S. \& Nicolson, S.W. 2004. Insect physiological ecology: mechanisms and patterns. Oxford University Press: Oxford, UK. 243 p.

Cossins, A.R. \& Bowler, K. 1987. Temperature biology of animals. Chapman and Hall: London, UK. $339 \mathrm{p}$.

Dahlgaard, J., Loeschcke, V., Michalak, P. \& Justesen, J. 1998. Induced thermotolerance and associated expression of the heat-shock protein Hsp70 in adult Drosophila melanogaster. Functional Ecology 12: 786-793.

Daly, H.V. 1985. Insect morphometrics. Annual Review of Entomology 30: 415-438.

David, J.R., Gibert, P., Legout, H., Pétavy, G., Capy, P. \& Moreteau, B. 2005. Isofemale lines in Drosophila: an empirical approach to quantitative trait analysis in natural populations. Heredity 94: 3-12. 
Denlinger, D.L. \& Lee, R.E. 1998. Physiology of cold sensitivity. (In Hallman, G.J. \& Denlinger, D.L., eds. Temperature sensitivity in insects and application in integrated pest management. Westview Press: Boulder. p. 55-95).

Denlinger, D.L. \& Lee, R.E. 2010. Low temperature biology of insects. Cambridge University Press: Cambridge, UK.

Denlinger, D.L. \& Yocum, G.D. 1998. Physiology of heat sensitivity. (In Hallman, G.J. \& Denlinger, D.L., eds. Temperature sensitivity in insects and application in integrated pest management. Westview Press: Boulder. p. 7-53).

Denlinger, D.L., Joplin, K.H., Chen, C.P. \& Lee, R.E. 1991. Cold shock and heat shock. (In Lee, R.E. \& Denlinger, D.L., eds. Insects at low temperatures. Chapman and Hall: New York. p. 131-148).

Dyar, H.G. 1890. The number of molts of lepidopterous larvae. Psyche 5: 420-422.

Ebenebe, A.A., Van den Berg, J. \& Van der Linde, T.C de K. 1999. Distribution and relative abundance of stalk borers of maize and sorghum in Lesotho. African Plant Protection 5: 77 82.

Eizaguirre, M., Lopez, C., Asin, L. \& Albajes, R. 1994. Thermoperiodism, photoperiodism and sensitive stage in the diapause induction of Sesamia nonagrioides (Lepidoptera: Noctuidae). Journal of Insect Physiology 40: 113-119.

Esperk, T. \& Tammaru, T. 2004. Does the 'investment principle' model explain moulting strategies in lepidopteran larvae? Physiological Entomology 29: 56-66.

Feder, M.E. 1996. Ecological and evolutionary physiology of stress proteins and the stress response: the Drosophila melanogaster model. (In Johnston, I.A. \& Bennett, A.F., eds. Animals and temperature: phenotypic and evolutionary adaptation. Cambridge University Press: Cambridge. p. 79-102).

Feder, M.E. 1999. Engineering candidate genes in studies of adaptation: the heat-shock protein Hsp70 in Drosophila melanogaster. American Naturalist Supplement 154: 55-66. 
Feder, M.E. \& Hofmann, G.E. 1999. Heat-shock proteins, molecular chaperones, and the stress response: evolutionary and ecological physiology. Annual Review of Physiology 61: 243-282.

Fischbacher, M. 1996. Relation between head capsule width and fresh weight in some caterpillar species (Lepidoptera: Geometridae, Tortricidae). Entomologia Generalis 20: 299303.

Gadenne, C., Dufour, M.C., Rossignol, F., Bécard, J.M. \& Couillaud, F. 1997. Occurrence of non-stationary larval moult during diapauses in the corn-stalk borer, Sesamia nonagrioides (Lepidoptera: Noctuidae). Journal of Insect Physiology 43: 425-431.

Gaines, J.C. \& Campbell, F.L. 1935. Dyar's rule as related to the number of instars of the corn ear worm, Heliothis obsoleta (Fab.), collected in the field. Annals of the Entomological Society of America 28: 445-461.

Goebel, R. 2006. The effect of temperature on development and reproduction of the sugarcane stalk borer, Chilo sacchariphagus (Bojer 1856) (Lepidoptera: Crambidae). African Entomology 14: 103-111.

Goldson, S.L., McNeill, M.R., Proffitt, J.R. \& Baird, D.B. 2001. Seasonal variation in larvalinstar head-capsule sizes of argentine stem weevil, Listronotus bonariensis (Kuschel) (Coleoptera: Curculionidae). Australian Journal of Entomology 40: 371-375.

Gotthard, K. 2004. Growth strategies and optimal body size in temperate Pararginii butterflies. Integrative and Comparative Biology 44: 471-479.

Gracey, A.Y., Logue, J., Tiku, P.E. \& Cossins, A.R. 1996. Adaptation of biological membranes to temperature: biophysical perspectives and molecular mechanisms. (In Johnston, I.A. \& Bennett, A.F., eds. Animals and temperature: phenotypic and evolutionary adaptation. Cambridge University Press: Cambridge. p. 1-21).

Gullan, P.J. \& Cranston, P.S. 2005. The insects: an outline of entomology. $3^{\text {rd }}$ ed. Oxford: Blackwell Publishing. 505 p.

Haile, A. \& Hofsvang, T. 2001. Survey of lepidopterous stem borer pests of sorghum, maize and pearl millet in Eritrea. Crop Protection 20: 151-157. 
Hammack, L., Ellsbury, M.M., Roehrdanz, R.L. \& Pikul Jr., J.L. 2003. Larval sampling and instar determination in field populations of northern and western corn rootworm (Coleoptera: Chrysomelidae). Journal of Economic Entomology 96: 1153-1159.

Harrington, R., Fleming, R.A. \& Woiwod, I.P. 2001. Climate change impacts on insect management and conservation in temperate regions: can they be predicted? Agricultural and Forest Entomology 3: 233-240.

Harris, K.M. 1962. Lepidopterous stem borers of cereals in Nigeria. Bulletin Entomological of Research 53: 139-171.

Harris, K.M. 1989. Recent advances in sorghum and pearl millet stem borer research. (In ICRISAT (International Crops Research Institute for the Semi-Arid Tropics). International Workshop on Sorghum Stem Borers, 17-20 Nov 1987, ICRISAT Center, India. Patancheru, A.P. 502 324, India: ICRISAT. p. 9-16).

Harris, K.M. \& Nwanze, K.F. 1992. Busseola fusca (Fuller), the African maize stem borer: a handbook of information. Information Bulletin no. 33. India: International Crops Research Institute for the Semi-Arid Tropics. Wallingford, UK: CAB International. 84 p.

Higley, L.G. \& Peterson, R.K.D. 1994. Initiating sampling programs. (In Pedigo, L.P. \& Buntin, G.D., eds. Handbook of sampling methods for arthropods in agriculture. CRC Press: Boca Raton, Florida, USA. p. 119-136).

IPCC. 2007. Climate Change 2007: Synthesis Report. Contribution of Working Groups I, II and III to the Fourth Assessment. Report of the Intergovernmental Panel on Climate Change. Geneva, Switzerland. 104 p.

Jackson, J.J \& Elliot, N.C. 1988. Temperature-dependent development of immature stages of the western corn rootworm, Diabrotica virgifera (Coleoptera: Chrysomelidae).

Environmental Entomology 17: 166-171.

Karimi-Malati, A., Fathipour, Y., Talebi, A.A. \& Bazoubandi, M. 2014. Life table parameters and survivorship of Spodoptera exigua (Lepidoptera: Noctuidae) at constant temperatures. Environmental Entomology 43: 795-803. 
Kelty, J.D. \& Lee, R.E. 2001. Rapid cold-hardening of Drosophila melanogaster (Diptera: Drosophilidae) during ecologically based thermoperiodic cycles. Journal of Experimental Biology 204: 1659-1666.

Kfir, R. 1991. Duration of diapause in the stem borers, Busseola fusca and Chilo partellus. Entomologia Experimentalis et Applicata 61: 265-270.

Kfir, R. 1998. Maize and grain sorghum: southern Africa. (In: Polaszek, A. ed. African cereal stem borers: economic importance, taxonomy, natural enemies and control. CAB International: Wallingford, UK. p. 29-37).

Kfir, R., Overholt, W.A., Khan, Z.R. \& Polaszek, A. 2002. Biology and management of economically important lepidopteran cereal stem borers in Africa. Annual Review of Entomology 47: 701-731.

Khadioli, N., Tonnang, Z.E.H., Ong'amo, G., Achia, T., Kipchirchir, I., Kroschel, J. \& Le Ru, B. 2014. Effect of temperature on the life history parameters of noctuid lepidopteran stem borers, Busseola fusca and Sesamia calamistis. Annals of Applied Biology 165: 373-386.

Kingsolver, J.G. \& Huey, R.B. 2008. Size, temperature, and fitness: three rules. Evolutionary Ecology Research 10: 251-268.

Kruger, M., Van Rensburg, J.B.J. \& Van den Berg, J. 2012. Transgenic Bt maize: farmers' perceptions refuge compliance and reports of stem borer resistance in South Africa. Journal of Applied Entomology 136: 38-50.

Le Ru, B.P., Ong'amo, G.O., Moyal, P., Muchungu, E., Ngala, L., Musyoka, B., Abdullah, Z., Matama-Kauma, T., Lada, V.Y., Pallangyo, K., Sidumo, A., Omwega, C., Schulthess, F., Calatayud, P.A. \& Silvain, J.F. 2006a. Major ecological characteristics of East African noctuid stem borers. Annales de la Société Entomologique de France 42: 353-361.

Le Ru, B.P., Ong'amo, G.O., Moyal, P., Ngala, L., Musyoka, B., Abdullah, Z., Cugala, D., Defabachew, B., Haile, T.A., Matama-Kauma, T., Lada, V.Y., Negassi, B., Pallangyo, K., Ravolonandrianina, J., Sidumo, A., Omwega, C.O., Schulthess, F., Calatayud, P.A. \& Silvain, J.F. 2006b. Diversity of lepidopteran stem borers on monocotyledonous plants in eastern Africa and the islands of Madagascar and Zanzibar revisited. Bulletin of Entomological Research 96: 1-9. 
Lee, R.E. 1989. Insect cold-hardiness: to freeze or not to freeze. Bioscience 39: 308-313.

Lee, R.E. \& Denlinger, D.L. 2010. Rapid cold-hardening: ecological significance and underpinning mechanisms. (In Denlinger, D.L. \& Lee, R.E., eds. Low temperature biology of insects. Cambridge University Press: Cambridge. p. 35-58).

Loeschcke, V., Krebs, R.A., Dahlgaard, J. \& Michalak, P. 1997. High-temperature stress and the evolution of thermal resistance in Drosophila. (In Bijlsma, R. \& Loeschcke, V., eds. Environmental stress, adaptation and evolution. Birkhäuser: Basel. p. 175-190).

Marco, V., Taberner, A. \& Castañera, P. 1997. Development and survival of immature Aubeonymus mariaefranciscae (Coleoptera: Curculionidae) at constant temperatures. Annals of the Entomological Society of America 90: 169-176.

McClellan, Q.C. \& Logan, J.A. 1994. Instar determination for the gypsy moth (Lepidoptera: Lymantriidae) based on the frequency distribution of head capsule widths. Environmental Entomology 23: 248-253.

McFarland, M., McCann, I.R. \& Kline, K.S. 1992. Synthesis and measurement of temperature for insect models. (In Goodenough, J.L \& McKinion, J.M., eds. Basics of insect modeling. American Society of Agricultural Engineers: St Joseph, MI, U.S.A. p. 7592).

Mira, A. 2000. Exuviae eating: a nitrogen meal? Journal of Insect Physiology 46: 605-610.

Mironidis, G.K. 2014. Development, survivorship and reproduction of Helicoverpa armigera (Lepidoptera: Noctuidae) under fluctuating temperatures. Bulletin of Entomological Research 104: 751-764.

Mironidis, G.K. \& Savopoulou-Soultani, M. 2008. Development, survivorship, and reproduction of Helicoverpa armigera (Lepidoptera: Noctuidae) under constant and alternating temperatures. Environmental Entomology 37: 16-28.

Mohyuddin, A. I. \& Greathead, D.J. 1970. An annotated list of the parasites of graminaceous stemborers in East Africa, with discussion of their potential in biological control. Entomophaga 15: 241-274. 
Ndemah, R., Schulthess, F., Le Ru, B. \& Bame, I. 2007. Lepidopteran cereal stemborers and associated natural enemies on maize and wild grass hosts in Cameroon. Journal of Applied Entomology 131: 658-668.

Nye, I.W.R. 1960. The insect pests of graminaceous crops in East Africa. Colonial Research Studies. Her Majesty's Stationary Office, London. 31: 1-48.

Nylin, S. \& Gotthard, K. 1998. Plasticity in life-history traits. Annual Review of Entomology 43: 63-83.

Ong'amo, G.O., Le Ru, B.P., Dupas, S., Moyal, P., Calatayud, P.A. \& Silvain, J.F. 2006. Distribution, pest status and agroclimatic preferences of lepidopteran stemborers of maize and sorghum in Kenya. Annales de la Société Entomologique de France 42: 171-177.

Onyango, F.O. \& Ochieng'-Odero, J.P.R. 1994. Continuous rearing of the maize stemborer Busseola fusca on an artificial diet. Entomologia Experimentalis et Applicata 73: 139-144.

Overgaard, J., Sørensen, J.G., Jensen, L.T., Loeschcke, V. \& Kristensen, T.N. 2010. Field tests reveal genetic variation for performance at low temperatures in Drosophila melanogaster. Functional Ecology 24: 186-195.

Panzavolta, T. 2007. Instar determination for Pissodes castaneus (Coleoptera: Curculionidae) using head capsule widths and lengths. Environmental Entomology 12: 219221.

Pörtner, H.O. 2001. Climate change and temperature-dependent biogeography: oxygen limitation of thermal tolerance in animals. Naturwissenschaften 88: 137-146.

Ramlov, H. 2000. Aspects of natural cold tolerance in ectothermic animals. Human Reproduction 15: 26-46.

Ratnadass, A., Traoré, T., Sylla, M. \& Diarra, D. 2001. Improved techniques for massrearing Busseola fusca (Lepidoptera: Noctuidae) on an artificial diet. African Entomology 9: $1-9$. 
Roy, M., Brodeur, J. \& Cloutier, C. 2003. Effect of temperature on intrinsic rates of natural increase $\left(r_{m}\right)$ of a coccinellid and its spider mite prey. Biocontrol 48: 57-72.

Scriber, J.M. \& Slansky, F. 1981. The nutritional ecology of immature insects. Annual Review of Entomology 26: 183-211.

Sehnal, F. 1985. Growth and life cycles. (In Kerkut, G.A. \& Gilbert, L.I., eds.

Comprehensive insect physiology, biochemistry and pharmacology: postembryonic development. Vol. 2. Pergamon Press: Oxford. p. 1-86).

Shanower, T.G., Schultess, F. \& Bosque-Perez, N. 1993. Development and fecundity of Sesamia calamistis (Lepidoptera: Noctuidae) and Eldana saccharina (Lepidoptera:

Pyralidae). Bulletin of Entomological Research 83: 237-243.

Sinclair, B.J. 2001. Field ecology of freeze tolerance: interannual variation in cooling rates, freeze-thaw and thermal stress in the microhabitat of the alpine cockroach Celatoblatta quinquemaculata. Oikos 93: 286-293.

Sithole, S.Z. 1989. Sorghum stemborers in southern Africa. (In Proceedings of the international workshop on sorghum stemborers, 17 - 20 November 1987, ICRISAT Centre, India, ICRISAT Patancheru. p. 41-47).

Slansky, F. \& Scriber, J.M. 1985. Food consumption and utilization. (In Kerkut, G.A. \& Gilbert, L.I., eds. Comprehensive insect physiology, biochemistry and pharmacology. Vol. 4. Permagon Press: Oxford. p. 87-163).

Smithers, C.N. 1960. Some recent observations on Busseola fusca (Fuller) (Lep., Noctuidae) in southern Rhodesia. Bulletin of Entomological Research 50: 809-819.

Sokal, R.R. \& Rohlf, F.J. 1995. Biometry: the principles and practice of statistics in biological research. $3^{\text {rd }}$ ed. New York, NY: W.H. Freeman and Company. 884 p.

Solomon, M.E. 1951. Control of humidity with potassium hydroxide, sulphuric acid or other solutions. Bulletin of Entomological Research 42: 543-554.

Somero, G.N. 1995. Proteins and temperature. Annual Review of Physiology 57: 43-68. 
Somero, G.N., Dahlhoff, E. \& Lin, J.J. 1996. Stenotherms and eurytherms: mechanisms establishing thermal optima and tolerance ranges. (In Johnston, I.A. \& Bennett, A.F., eds. Animals and temperature: phenotypic and evolutionary adaptation. Cambridge University Press: Cambridge. p. 53-78).

Speight, M.R., Hunter, M.D. \& Watt, A.D. 2008. Ecology of insects: concepts and applications. $2^{\text {nd }}$ ed. John Wiley \& Sons Ltd, UK. 628 p.

StatSoft, Inc. 2013. STATISTICA (data analysis software system), version 12. www.statsoft.com.

Stockoff, B.A. 1993. Ontogenetic change in dietary selection for protein and lipid by gypsy moth larvae. Journal of Insect Physiology 39: 677-686.

Sutherst, R.W. 2000. Climate change and invasive species - a conceptual framework. (In Mooney, H.A. \& Hobbs, R.J., eds. Invasive species in a changing world. Island Press: Washington, DC. p. 211-240).

Tamiru, A., Getu, E., Jembere, B. \& Bruce, T. 2012. Effect of temperature and relative humidity on the development and fecundity of Chilo partellus (Swinhoe) (Lepidoptera: Crambidae). Bulletin of Entomological Research 102: 9-15.

Tams, W.H.T. \& Bowden, J. 1953. A revision of the African species of Sesamia Guenée and related genera (Agrotidae-Lepidoptera). Bulletin of Entomological Research 43: 645678.

Terblanche, J.S. 2013. Thermal relations. (In Chapman, R.F., Simpson, S.J. \& Douglas, A.E., eds. The insects: structure and function. $5^{\text {th }}$ ed. Cambridge University Press: Cambridge, UK. p. 588-621).

Unnithan, G.C. 1987. Development and reproductive biology of the maize stem borer Busseola fusca Fuller (Lepidoptera: Noctuidae). Journal of Applied Entomology 104: 172179.

Usua, E.J. 1968. Temperature and relative humidity effects on the development of immature stages of the maize stem borers Busseola fusca and Sesamia calamistis. Journal of Economic Entomology 61: 1091-1093. 
Van Rensburg, G.D.J \& Bate, R. 1987. Preliminary studies on the relative abundance and distribution of the stalk borers Busseola fusca and Chilo partellus. Technical Communication, Department of Agriculture and Water Supply, Republic of South Africa, 212: 49-52.

Van Rensburg, J.B.J. 1997. Seasonal moth flight activity of the maize stalk borer, Busseola fusca (Fuller) (Lepidoptera: Noctuidae) in small farming areas of South Africa. Applied Plant Science 11: 20-23.

Van Rensburg, J.B.J., Walters, M.C. \& Giliomee, J.H. 1987. Ecology of the maize stalkborer, Busseola fusca Fuller (Lepidoptera: Noctuidae). Bulletin of Entomological Research 77: 255-269.

Vannier, G. 1994. The thermobiological limits of some freezing tolerant insects: the supercooling and thermo-stupor points. Acta Oecologica 15: 31-42.

Waladde, S.M., Van den Berg, J., Botlohle, P.M. \& Mlanjeni, N. 2001. Survey of the abundance and distribution of maize stemborers in the Eastern Cape province of South Africa. (In Van den Berg, J. \& Uys, V.M., eds. Proceedings of the final Workshop of the Southern African Stem Borer Management Programme: 2001, $13^{\text {th }}$ Congress of the Entomological Society of southern Africa, Pietermaritzburg. p. 13-16).

Waldbauer, G.P. \& Friedman, S. 1991. Self-selection of optimal diets by insects. Annual Review of Entomology 36: 43-63.

Waldstein, D.E. \& Reissig, W.H. 2001. Apple damage, pest phenology, and factors influencing the efficacy of tebufenozide for control of oblique banded leafroller (Lepidoptera: Tortricidae). Journal of Economic Entomology 94: 673-679.

Waters, J.S. \& Harrison, J.F. 2012. Insect metabolic rates. (In Sibly, R.M., Brown, J.H., Kodric-Brown, A., eds. Metabolic ecology: a scaling approach. John Wiley \& Sons Ltd, UK. p. 198-217).

Way, M. 1995. Developmental biology of the immature stages of Eldana saccharina Walker (Lepidoptera: Pyralidae). Proceeding of the South African Sugar Technologists' Association 69: 83-86. 
Williams, D.G. \& McDonald, G. 1982. The duration and number of the immature stage of codling moth Cydia pomonella (L.) (Tortricidae: Lepidoptera). Journal of the Australian Entomological Society 21: 1-4.

Wilson, L.T. \& Barnett, W.W. 1983. Degree-days: an aid in crop and pest management. California Agriculture 37: 4-7.

Yarro, J.G. 1985. Effect of host plant on moulting in the African armyworm Spodoptera exempta (Walk.) (Lepidoptera: Noctuidae) at constant temperature and humidity conditions. Insect Science and its Application 6: 171-175. 

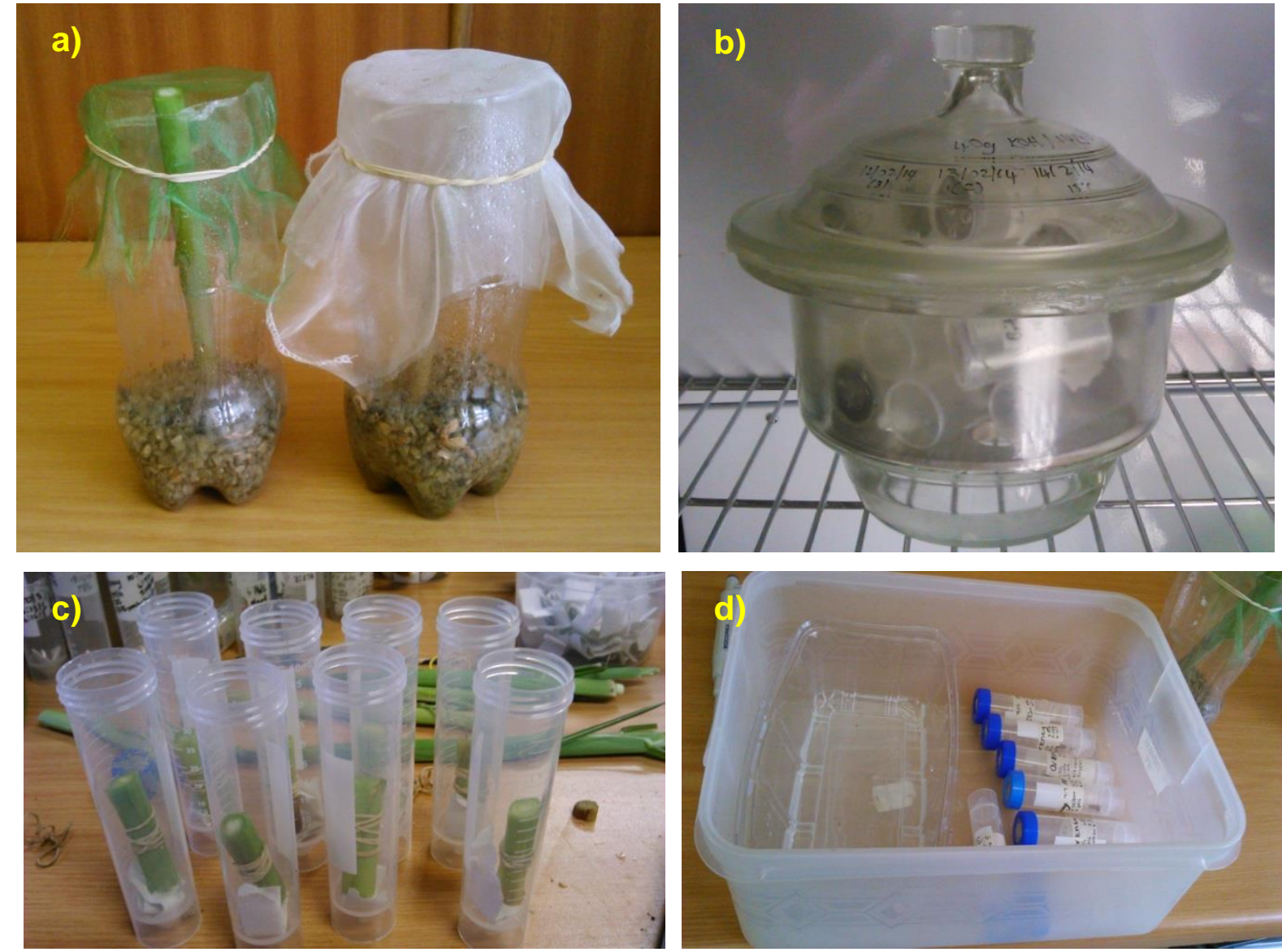

Figure 2.1: Containers used for rearing of Busseola fusca: a) oviposition chambers with one cut maize stem per moth pair; b) desiccator with small plastic containers for egg development; c) test tubes used for larval development; d) plastic container with water and test tubes containing pupae.

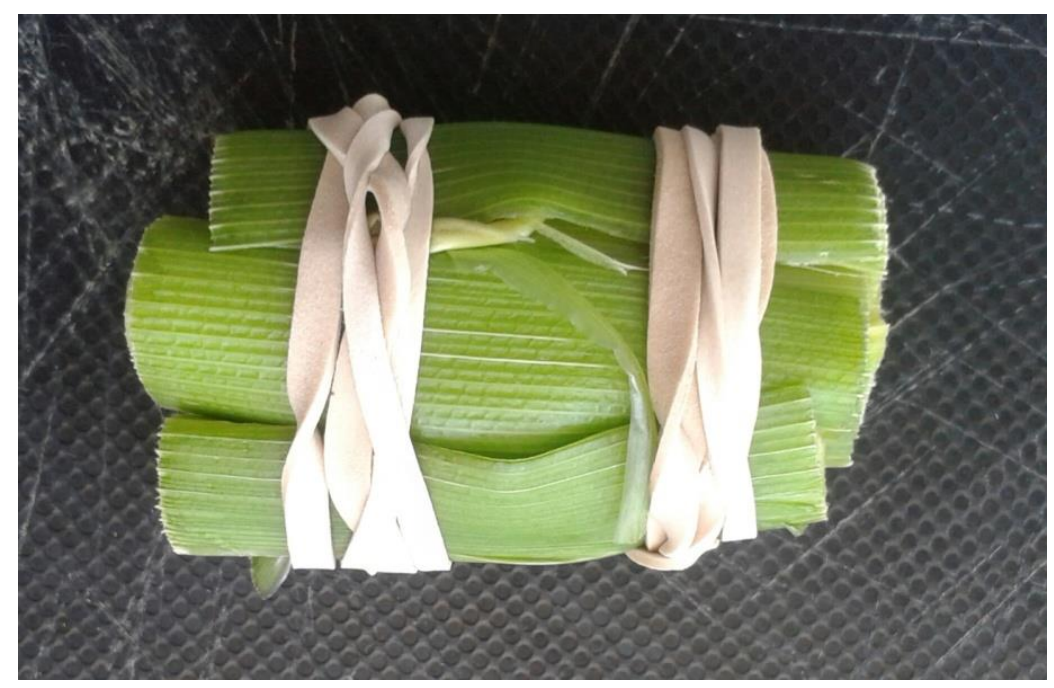

Figure 2.2: Temperature and $\mathrm{RH}$ recorded inside a maize stem with an iButton ${ }^{\circledR}$. 

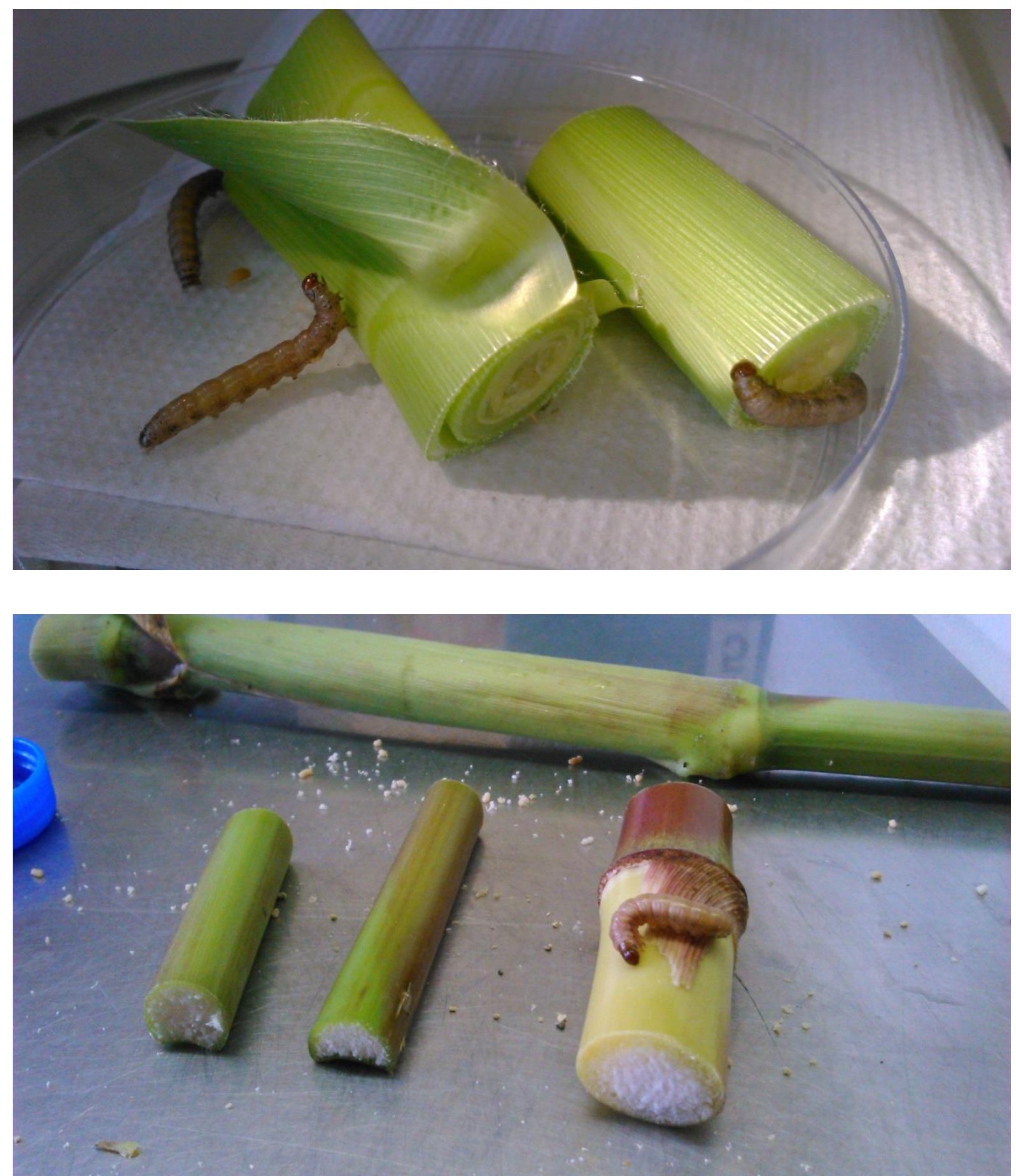

Figure 2.3: Busseola fusca larvae where fed with compact unfolded leaves from the second to the fifth instar (above) and a piece of maize stem from the six instar onwards (bottom). 

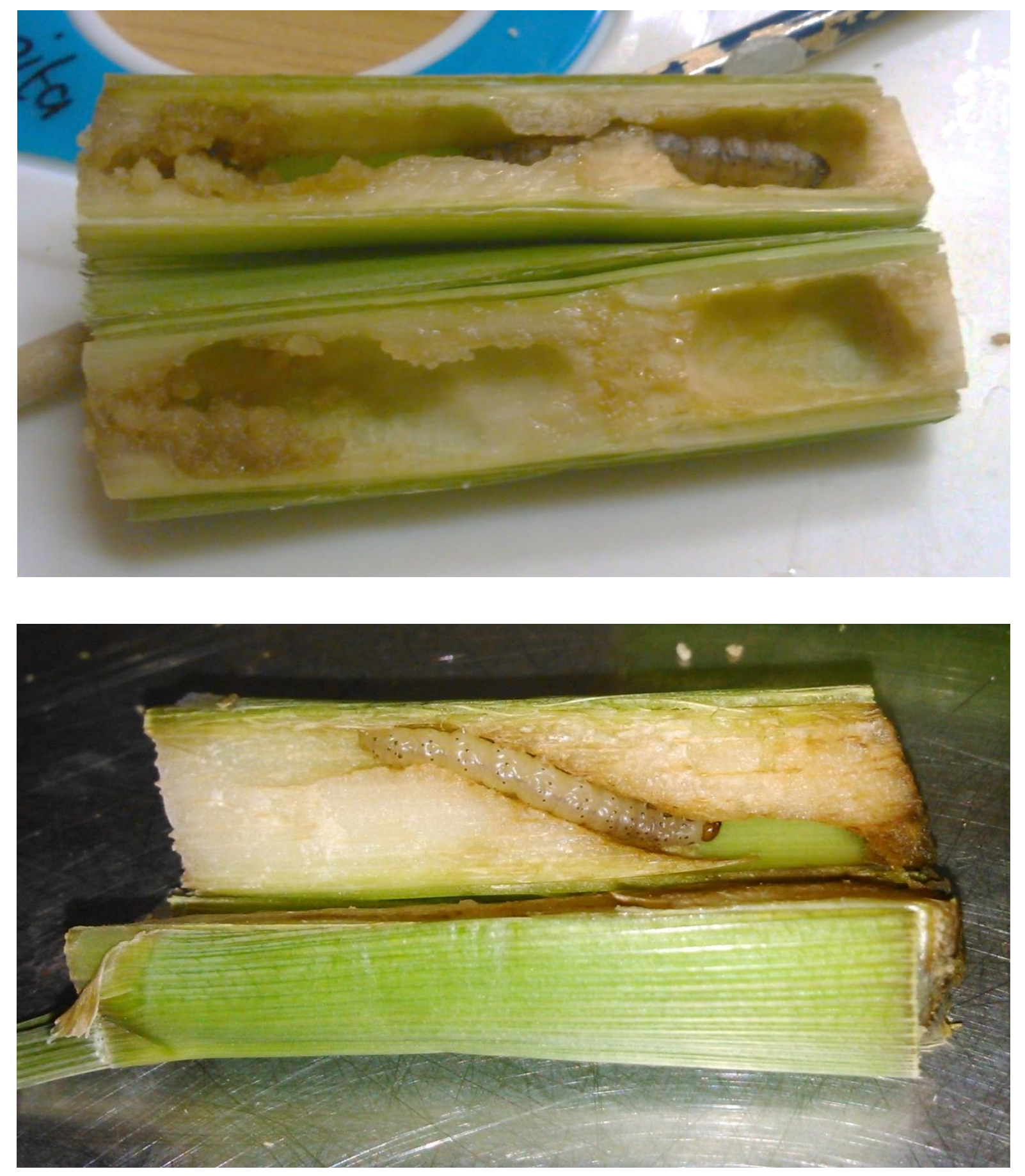

Figure 2.4: Damage by Busseola fusca larvae through tunnelling into maize stems. 


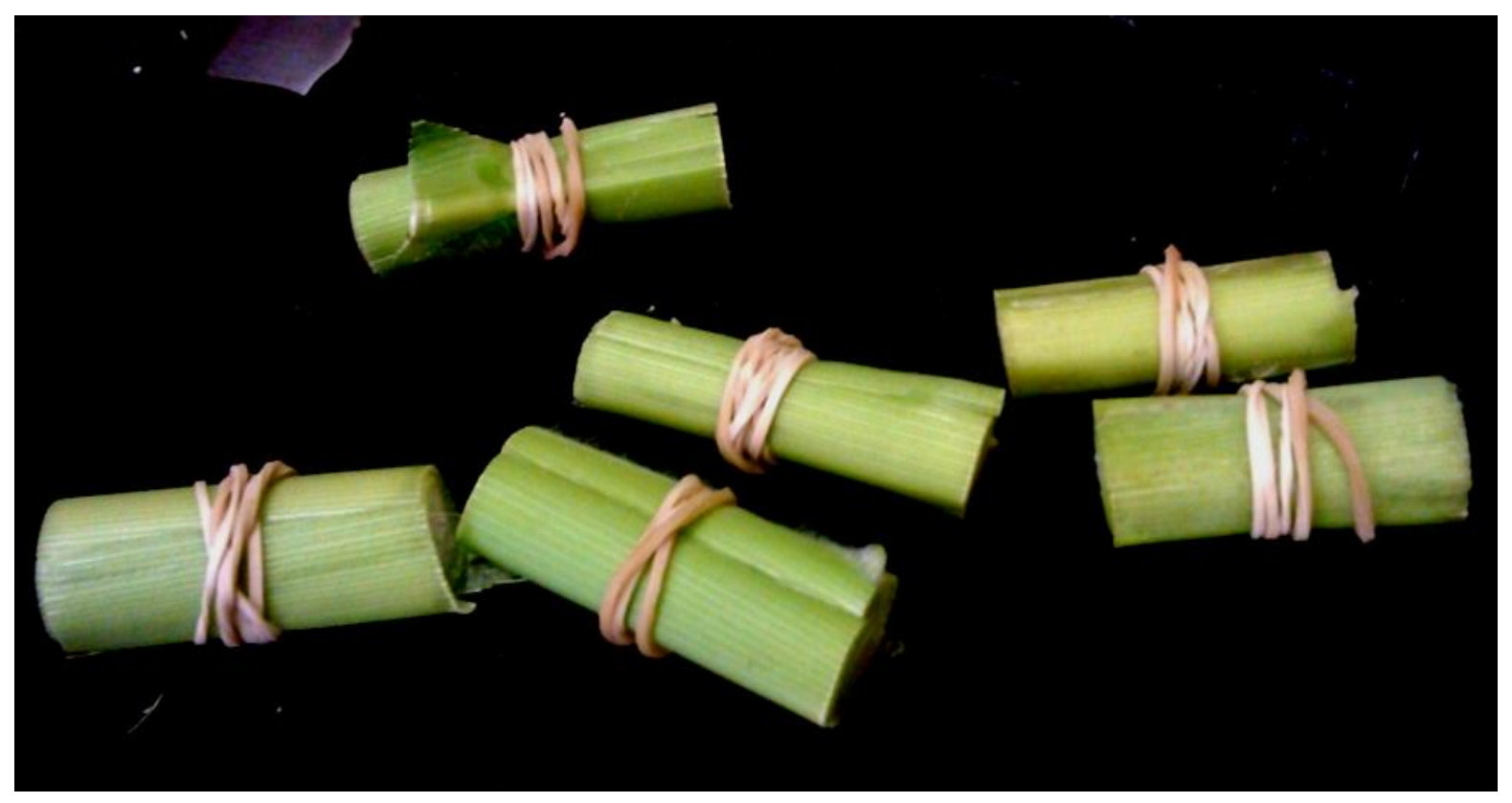

Figure 2.5: Piece of maize plant cut longitudinally and kept together with an elastic band for daily observation of $B$. fusca larvae. 
Instar 1

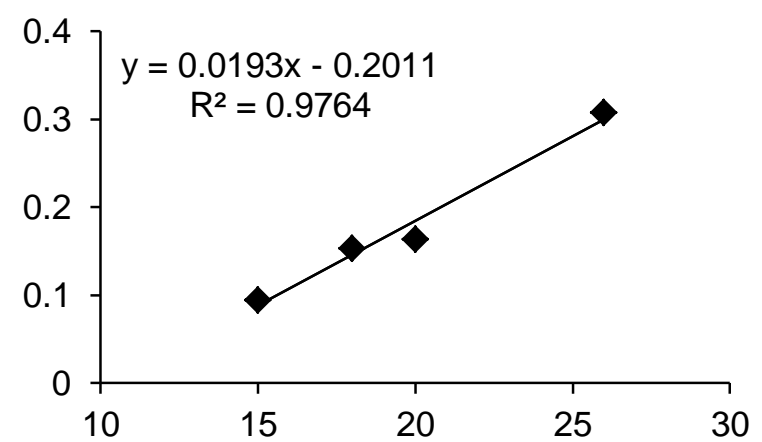

Instar 3

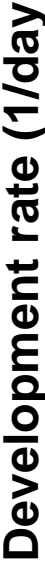

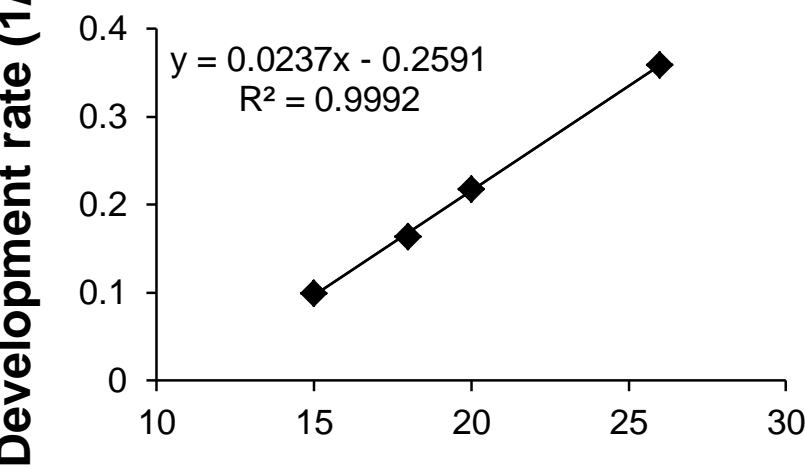

Instar 5

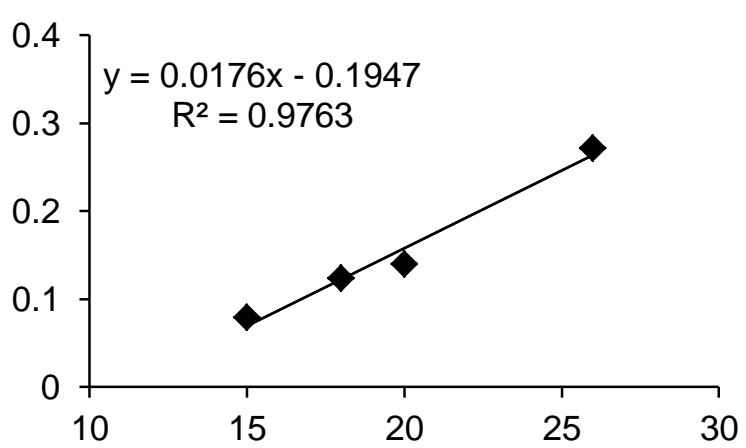

Instar 2

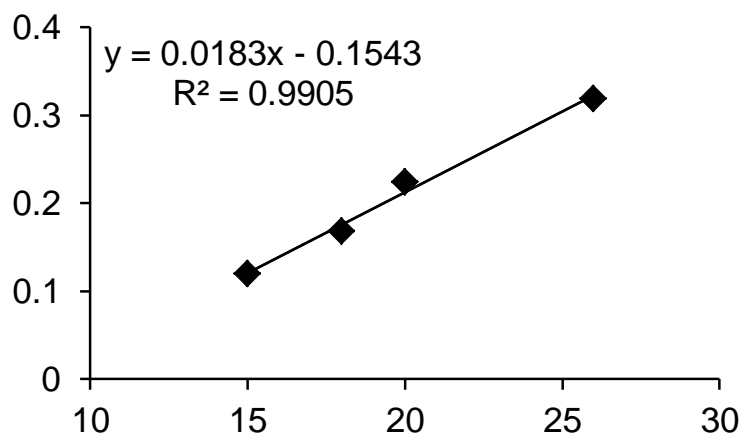

Instar 4

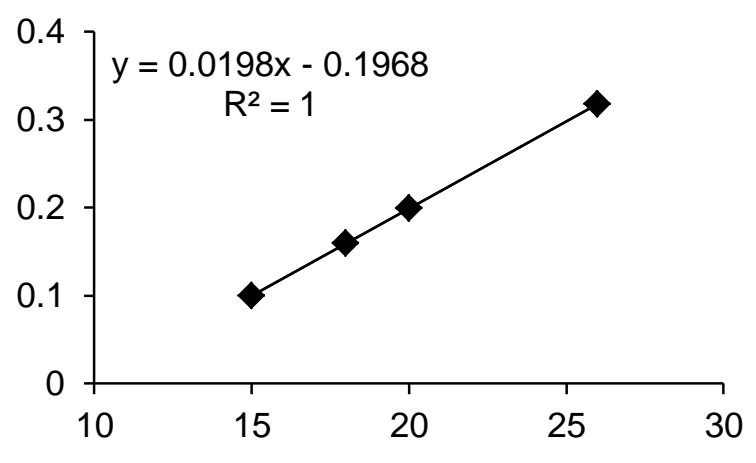

Instar 6

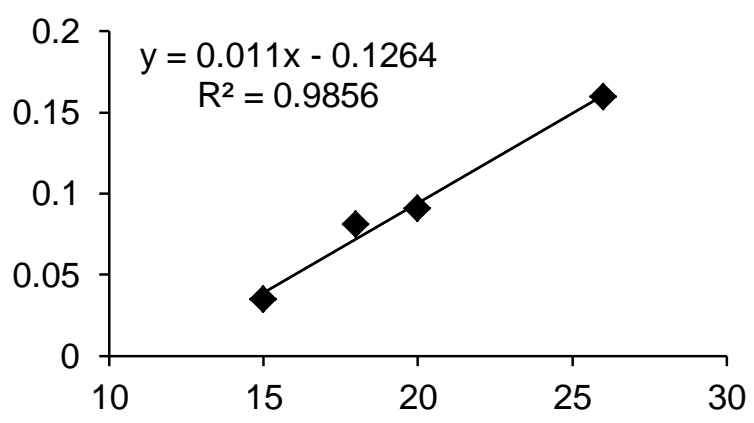

\section{Temperature $\left({ }^{\circ} \mathrm{C}\right)$}

Figure 2.6: The relationship between Busseola fusca development rates and rearing temperature for larval instar one to six. 


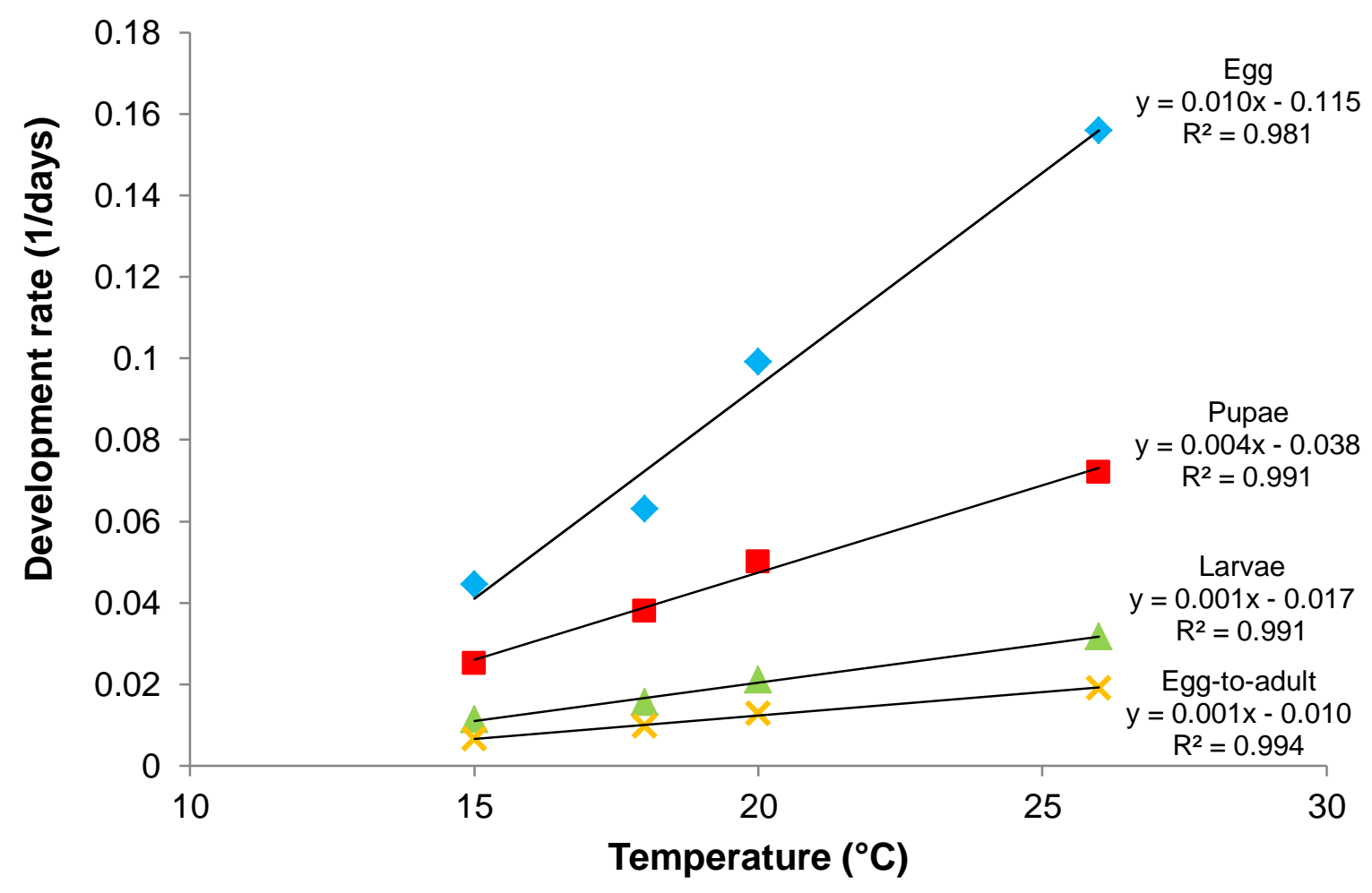

Figure 2.7: The relationship between development rates and rearing temperature for eggs, larvae, pupae and egg-to-adult stages of Busseola fusca. (Development rates for larvae and egg-to-adult stage include instars 7 and 8 ). 


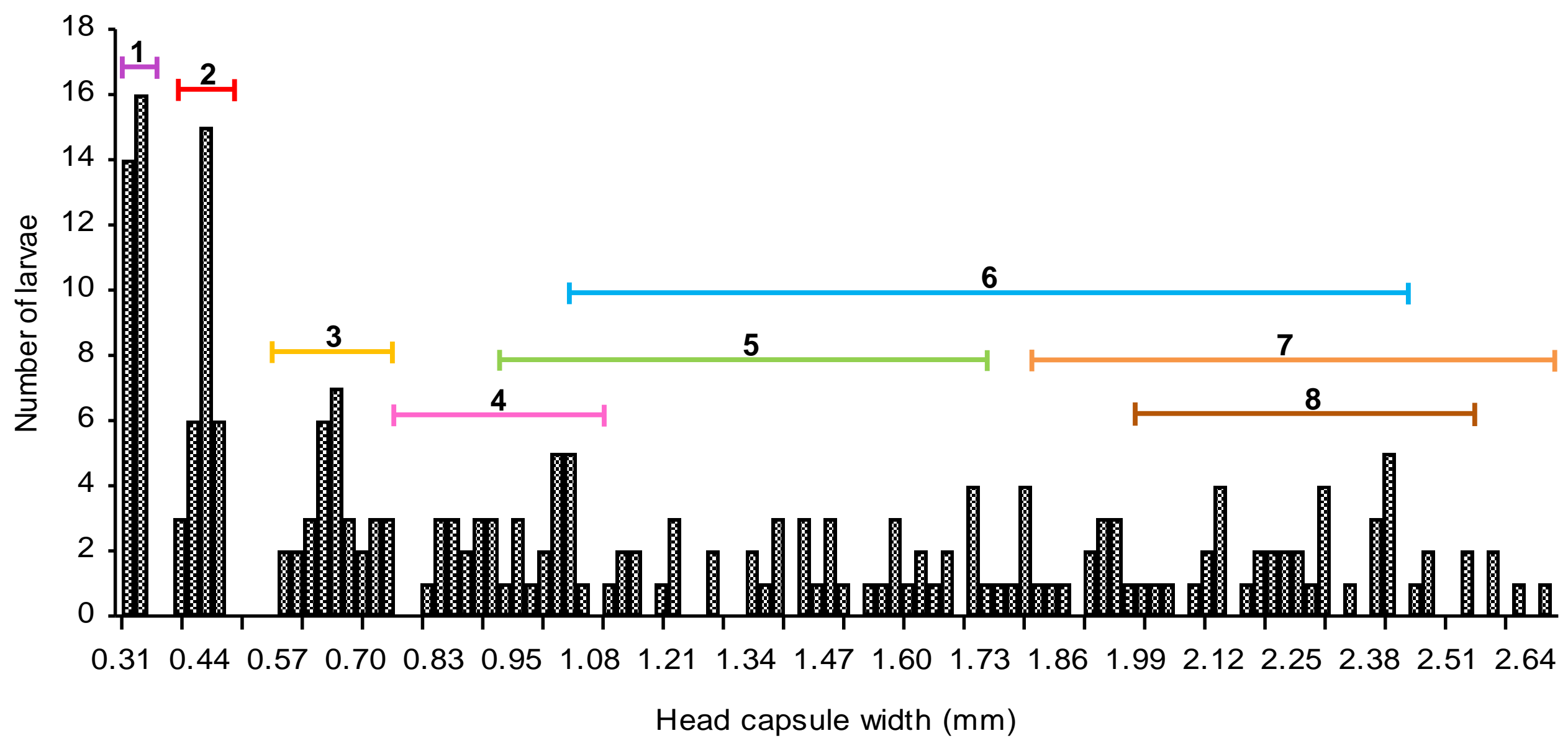

Figure 2.8: Frequency distribution of head capsule widths of Busseola fusca larvae. Each coloured line indicates the range of a specific instar. 


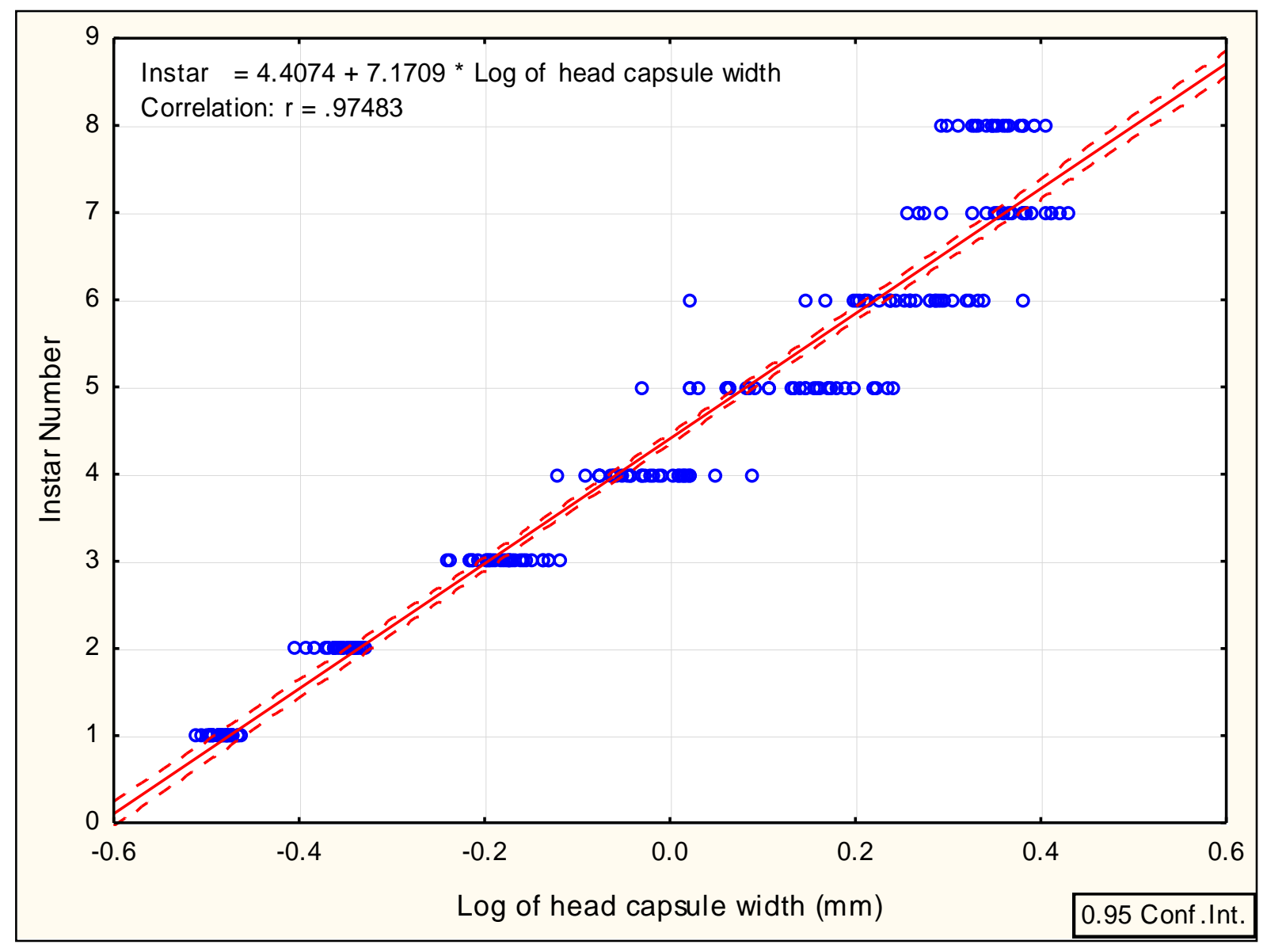

Figure 2.9: Relationship between head capsule width and instar of Busseola fusca larvae. The linear regression shows a straight line which fitted Dyar's rule. 


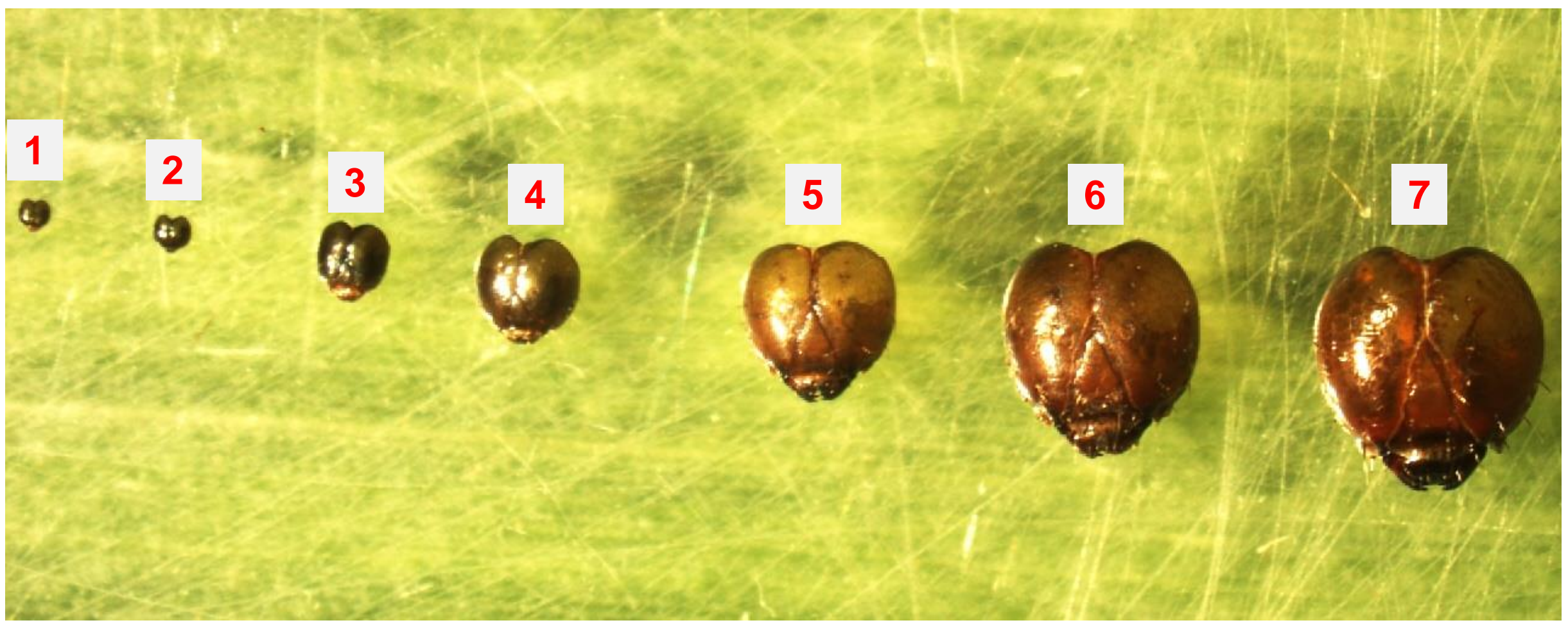

Figure 2.10: Head capsules of Busseola fusca larvae indicating instars one to seven. 
Table 2.1: Mean development time (days \pm S.E.) of different life stages and larval survival of Busseola fusca at constant temperatures. The range of days to develop is shown in brackets.

\begin{tabular}{|c|c|c|c|c|c|}
\hline $\begin{array}{l}\text { Temperature } \\
\left( \pm 1^{\circ} \mathrm{C}\right)\end{array}$ & 15 & 18 & 20 & 26 & 30 \\
\hline Egg & $\begin{array}{c}22.5 \pm 0.2 \mathrm{a} \\
(21-24)\end{array}$ & $\begin{array}{c}12.8 \pm 0.1 b \\
(12-13)\end{array}$ & $\begin{array}{c}10.2 \pm 0.2 c \\
(9-12)\end{array}$ & $\begin{array}{c}6.5 \pm 0.1 d \\
(6-8)\end{array}$ & $\begin{array}{c}5.9 \pm 0.04 \mathrm{e} \\
(5-6)\end{array}$ \\
\hline Instar 1 & $\begin{array}{l}10.6 \pm 0.3 a \\
(8-9)\end{array}$ & $\begin{array}{c}6.8 \pm 0.4 b \\
(5-10)\end{array}$ & $\begin{array}{c}6.1 \pm 0.1 c \\
(6-7)\end{array}$ & $\begin{array}{c}3.3 \pm 0.1 d \\
(3-5)\end{array}$ & $\begin{array}{c}3.2 \pm 0.1 d \\
(3-5)\end{array}$ \\
\hline Instar 2 & $\begin{array}{c}8.4 \pm 0.3 a \\
(8-9)\end{array}$ & $\begin{array}{c}6.0 \pm 0.2 b \\
(5-7)\end{array}$ & $\begin{array}{c}4.5 \pm 0.1 c \\
(4-5)\end{array}$ & $\begin{array}{c}3.3 \pm 0.1 d \\
(2-8)\end{array}$ & $\begin{array}{c}2.6 \pm 0.1 \mathrm{e} \\
(2-4)\end{array}$ \\
\hline Instar 3 & $\begin{array}{l}10.2 \pm 0.6 \mathrm{a} \\
\quad(9-12)\end{array}$ & $\begin{array}{c}6.3 \pm 0.3 b \\
(5-9)\end{array}$ & $\begin{array}{c}4.7 \pm 0.1 c \\
(4-5)\end{array}$ & $\begin{array}{c}2.9 \pm 0.1 d \\
(2-4)\end{array}$ & $\begin{array}{c}2.9 \pm 0.1 d \\
(2-6)\end{array}$ \\
\hline Instar 4 & $\begin{array}{c}10.2 \pm 0.7 \mathrm{a} \\
(9-13)\end{array}$ & $\begin{array}{c}6.3 \pm 0.2 b \\
(5-8)\end{array}$ & $\begin{array}{l}5.2 \pm 0.2 c \\
\quad(4-8)\end{array}$ & $\begin{array}{l}3.2 \pm 0.1 d \\
(2-4)\end{array}$ & $\begin{array}{c}3.1 \pm 0.2 d \\
(2-6)\end{array}$ \\
\hline Instar 5 & $\begin{array}{c}12.8 \pm 0.8 \mathrm{a} \\
(11-15)\end{array}$ & $\begin{array}{c}8.5 \pm 0.6 b \\
(6-12)\end{array}$ & $\begin{array}{c}7.3 \pm 0.2 c \\
(5-9)\end{array}$ & $\begin{array}{c}3.9 \pm 0.2 d \\
(2-9)\end{array}$ & $\begin{array}{c}4.3 \pm 0.20 d \\
(1-7)\end{array}$ \\
\hline Instar 6 & $\begin{array}{c}29.2 \pm 1.4 \mathrm{a} \\
(24-32)\end{array}$ & $\begin{array}{l}14.1 \pm 1.9 b \\
(9-30)\end{array}$ & $\begin{array}{c}13.7 \pm 1.0 b \\
(4-23)\end{array}$ & $\begin{array}{c}8.5 \pm 0.7 c \\
(2-18)\end{array}$ & $\begin{array}{c}9.5 \pm 0.8 c \\
(3-23)\end{array}$ \\
\hline Instar 7 & $\begin{array}{c}44.0 \pm 0.0 \mathrm{a} \\
(44)\end{array}$ & $\begin{array}{c}20.9 \pm 1.3 b \\
(14-27)\end{array}$ & $\begin{array}{c}14.4 \pm 0.9 c \\
(6-18)\end{array}$ & $\begin{array}{c}11.2 \pm 0.5 \mathrm{~cd} \\
(5-16)\end{array}$ & $\begin{array}{c}12.7 \pm 0.7 d \\
(8-22)\end{array}$ \\
\hline Instar $\mathbf{8}^{*}$ & - & $\begin{array}{c}17.0 \pm 0.0 \\
(17) \\
\end{array}$ & $\begin{array}{c}17.0 \pm 0.0 \\
(17)\end{array}$ & $\begin{array}{c}11.0 \pm 0.0 \\
(11)\end{array}$ & $\begin{array}{c}9.0 \pm 0.0 \\
(9)\end{array}$ \\
\hline Larvae & $\begin{array}{c}90.2 \pm 8.0 \mathrm{a} \\
(81-122) \\
\end{array}$ & $\begin{array}{c}65.1 \pm 2.0 \mathrm{~b} \\
(55-75)\end{array}$ & $\begin{array}{c}47.7 \pm 0.8 c \\
(42-57)\end{array}$ & $\begin{array}{c}32.1 \pm 0.6 \mathrm{~d} \\
(27-47)\end{array}$ & $\begin{array}{c}33.4 \pm 0.9 d \\
(25-46)\end{array}$ \\
\hline Pupae & $\begin{array}{c}40.0 \pm 0.8 a \\
(38-43)\end{array}$ & $\begin{array}{c}26.4 \pm 0.4 b \\
(25-29)\end{array}$ & $\begin{array}{c}20.0 \pm 0.2 c \\
(18-22)\end{array}$ & $\begin{array}{c}14.0 \pm 0.2 \mathrm{~d} \\
(12-18)\end{array}$ & $\begin{array}{c}13.3 \pm 0.2 d \\
(11-17)\end{array}$ \\
\hline Egg-to-adult & $\begin{array}{c}152.6 \pm 8.6 \mathrm{a} \\
(143-187)\end{array}$ & $\begin{array}{c}104.3 \pm 2.1 b \\
(93-114)\end{array}$ & $\begin{array}{c}77.8 \pm 0.8 c \\
(70-88)\end{array}$ & $\begin{array}{c}52.6 \pm 0.7 \mathrm{~d} \\
(46-67)\end{array}$ & $\begin{array}{c}52.6 \pm 0.9 d \\
(45-66)\end{array}$ \\
\hline $\begin{array}{l}\text { Larval } \\
\text { survival (\%) }\end{array}$ & 3.3 & 7.7 & 24.8 & 18.7 & 15.5 \\
\hline
\end{tabular}

Means within the same row followed by the same letter do not differ significantly at $P=0.05$ (Tukey's HSD).

${ }^{*}$ Data not included in ANOVA analysis due to small sample size. 
Table 2.2: Linear regression equations describing the relationship between development rate $(1 /$ days $)$ and temperature $\left(15-26^{\circ} \mathrm{C}\right)$ and the thermal requirements of different developmental stages of Busseola fusca.

\begin{tabular}{cllll}
\hline Development stage & Regression model & k \pm S.E. & t \pm S.E. & r-value \\
\hline Eggs & $y=0.0101 x-0.1041$ & $99.50 \pm 1.92$ & $10.36 \pm 0.33$ & 0.98 \\
First instar & $y=0.0207 x-0.2368$ & $48.31 \pm 2.27$ & $11.44 \pm 0.48$ & 0.92 \\
Second instar & $y=0.0178 x-0.1400$ & $56.18 \pm 3.47$ & $7.78 \pm 1.46$ & 0.86 \\
Third instar & $y=0.0238 x-0.2600$ & $42.02 \pm 2.61$ & $10.92 \pm 0.97$ & 0.86 \\
Fourth instar & $y=0.0198 x-0.0197$ & $50.51 \pm 2.76$ & $9.92 \pm 0.99$ & 0.89 \\
Fifth instar & $y=0.0197 x-0.2408$ & $50.89 \pm 3.70$ & $12.26 \pm 0.78$ & 0.82 \\
Sixth instar & $y=0.0099 x-0.1049$ & $101.32 \pm 19.79$ & $10.63 \pm 4.16$ & 0.48 \\
Pupal stage & $y=0.0041 x-0.0331$ & $246.25 \pm 7.96$ & $8.14 \pm 1.67$ & 0.96 \\
All Instar stages & $y=0.0019 x-0.0168$ & $536.48 \pm 22.83$ & $8.99 \pm 1.37$ & 0.93 \\
Egg-to-Adult & $y=0.0011 x-0.0099$ & $893.66 \pm 26.91$ & $8.84 \pm 1.08$ & 0.96 \\
\hline
\end{tabular}

$\mathrm{t}=$ estimated lower temperature threshold, $\mathrm{k}=$ estimated thermal requirement in degree-days 
Table 2.3: $\quad$ Mean development time in days and degree-days ( $\left.{ }^{\circ} \mathrm{D}\right)$ for Busseola fusca at constant temperatures from $15-26^{\circ} \mathrm{C}$. Degree-days were calculated using the lower threshold temperature for development determined for each developmental stage (eggs $=10.36{ }^{\circ} \mathrm{C}$, larvae $=8.99^{\circ} \mathrm{C}$, pupae $=8.14^{\circ} \mathrm{C}$ and egg-to-adult $=8.84^{\circ} \mathrm{C}$ ).

\begin{tabular}{llllll}
\hline $\begin{array}{l}\text { Development } \\
\text { Stage }\end{array}$ & $\begin{array}{l}\text { Temperature } \\
\left({ }^{\circ} \mathbf{C}\right)\end{array}$ & $\mathbf{n}$ & $\begin{array}{l}\text { Development time } \\
\text { (days } \pm \text { S.E.) }\end{array}$ & Range & ${ }^{\circ} \mathbf{D} \pm$ S.E. \\
\hline Egg & 15 & 5 & $22.47 \pm 0.17$ & $21-24$ & $104.9 \pm 1.9$ \\
& 18 & 12 & $12.76 \pm 0.07$ & $12-13$ & $97.4 \pm 1.0$ \\
& 20 & 31 & $10.17 \pm 0.17$ & $9-12$ & $98.0 \pm 1.6$ \\
& 26 & 43 & $6.47 \pm 0.12$ & $6-8$ & $101.1 \pm 1.8$ \\
\hline Mean & & & & & $99.58 \pm 0.98$ \\
\hline Larvae & 15 & 5 & $90.20 \pm 7.97$ & $81-122$ & $542.1 \pm 47.9$ \\
& 18 & 12 & $65.08 \pm 2.04$ & $55-75$ & $586.4 \pm 18.3$ \\
& 20 & 31 & $47.65 \pm 0.75$ & $42-57$ & $524.6 \pm 8.2$ \\
\hline Mean & 26 & 43 & $32.07 \pm 0.61$ & $27-47$ & $545.5 \pm 10.4$ \\
\hline Pupae & 15 & & & & $543.58 \pm 6.8$ \\
\hline Mean & 5 & $40.00 \pm 0.84$ & $38-43$ & $274.4 \pm 5.7$ \\
& 18 & 12 & $26.42 \pm 0.38$ & $25-29$ & $260.5 \pm 3.7$ \\
\hline Egg-to-adult & 15 & 31 & $20.00 \pm 0.15$ & $18-22$ & $251.9 \pm 5.8$ \\
& 20 & 43 & $13.98 \pm 0.19$ & $12-18$ & $249.6 \pm 3.4$ \\
\hline Mean & 18 & 5 & $152.60 \pm 8.61$ & $143-187$ & $940.0 \pm 53.0$ \\
& 20 & 12 & $104.25 \pm 2.11$ & $93-114$ & $954.9 \pm 19.3$ \\
& 26 & 31 & $77.81 \pm 0.84$ & $70-88$ & $868.3 \pm 9.4$ \\
& & 43 & $52.61 \pm 0.65$ & $46-67$ & $902.7 \pm 11.2$ \\
\hline
\end{tabular}


Table 2.4: Mean head capsule widths and ranges for each Busseola fusca larval instar stage and Dyar's ratio.

\begin{tabular}{cccccc}
\hline Instar & $\mathbf{n}$ & Range $(\mathbf{m m})$ & Range Size & Mean \pm S.E. & Dyar's ratio \\
\hline $\mathbf{1}$ & 30 & $0.31-0.34$ & 0.04 & $0.33 \pm 0.002$ & - \\
$\mathbf{2}$ & 30 & $0.39-0.47$ & 0.08 & $0.44 \pm 0.003$ & 1.35 \\
$\mathbf{3}$ & 30 & $0.57-0.76$ & 0.19 & $0.66 \pm 0.009$ & 1.49 \\
$\mathbf{4}$ & 31 & $0.75-1.23$ & 0.47 & $0.95 \pm 0.018$ & 1.43 \\
$\mathbf{5}$ & 31 & $0.93-1.74$ & 0.80 & $1.36 \pm 0.036$ & 1.43 \\
$\mathbf{6}$ & 32 & $1.05-2.40$ & 1.35 & $1.80 \pm 0.046$ & 1.33 \\
$\mathbf{7}$ & 21 & $1.80-2.68$ & 0.89 & $2.30 \pm 0.057$ & 1.28 \\
$\mathbf{8}$ & 20 & $1.96-2.54$ & 0.58 & $2.26 \pm 0.036$ & 0.98 \\
\hline
\end{tabular}




\section{CHAPTER 3}

\section{The effect of temperature on reproduction of Busseola fusca (Lepidoptera: Noctuidae)}

\subsection{Abstract}

Temperature is an important factor affecting reproductive parameters of insect species. Knowledge on the effect of temperature on reproduction will provide insight into population dynamics and contribute to prediction of pest outbreaks. The aim of this study was to determine the effect of temperature on reproduction parameters of Busseola fusca. A laboratory study was conducted using four different constant temperatures namely 15,20 , 26 and $30 \pm 1{ }^{\circ} \mathrm{C}, 70 \pm 30 \% \mathrm{RH}$ and $14 \mathrm{~L}$ : 10D photoperiod. Oviposition occurred at all the temperatures evaluated, but eggs laid at a constant temperature of $30^{\circ} \mathrm{C}$ were infertile. The total number of eggs laid by $B$. fusca females was 300 - 400 eggs at temperatures between 15 and $26{ }^{\circ} \mathrm{C}$. Longevity of females also decreased at $30^{\circ} \mathrm{C}$. There was a longer pre- and post-oviposition period at $15^{\circ} \mathrm{C}$ and the minimum number of eggs laid at $15^{\circ} \mathrm{C}$ was fewer than at 20 and $26{ }^{\circ} \mathrm{C}$. The total number of eggs laid per female at $15^{\circ} \mathrm{C}$ was, however, not fewer than at 20 and $26^{\circ} \mathrm{C}$, but a high percentage of these eggs were infertile. In addition, most of the larvae that developed to the black head stage at $15^{\circ} \mathrm{C}$ were unable to hatch. The lower threshold temperature for reproduction of $B$. fusca is therefore higher than $15^{\circ} \mathrm{C}$ and the upper threshold temperature, below $30{ }^{\circ} \mathrm{C}$. Results from this study indicate the optimum temperature for oviposition and fertility to be between $20-26{ }^{\circ} \mathrm{C}$.

Key words: Busseola fusca, fertility, longevity, reproduction, temperature 


\subsection{Introduction}

\subsubsection{The effect of temperature on reproduction}

Reproductive success is very important in evaluating the ecological fitness of an insect and will contribute to understanding the evolutionary biology of the insect (Fantinou et al., 2004). Temperature is considered to be one of the most important abiotic factors affecting various life history parameters of insects (Hallman \& Denlinger, 1998; He et al., 2003). Reproduction parameters such as the length of oviposition period, overall fecundity and egg viability are directly affected by temperature (Kim \& Lee, 2003; Son \& Lewis, 2005; Ali \& Rizvi, 2008).

Understanding the effect of temperature on reproduction of an insect will not only contribute to the prediction of oviposition period, but also population growth rate and pest status (Son \& Lewis, 2005). Therefore, the impact of climate change on pest population growth can be predicted by determining the upper and lower temperature thresholds of the population. Oviposition models can include temperature-dependent elements such as overall fecundity and duration of age-specific oviposition and survival (Son \& Lewis, 2005). Mathematical models can be used to predict population dynamics (Sporleder et al., 2004) and species distribution (Hauptfleisch et al., 2014). For example, in an assessment of the potential of Busseola fusca (Lepidoptera: Noctuidae) as a pest in sorghum and maize growing countries around the world by Hauptfleisch et al. (2014), it was indicated that if introduced, B. fusca may establish and become a pest in most of the maize growing regions globally. According to the model, it might do especially well along the east coast of Brazil, Madagascar, and in Indonesia and Thailand.

Improved knowledge on the effects of temperature on $B$. fusca biology will assist in modelling climate requirements of $B$. fusca in different regions where different clades with different ecological characteristics occur (Sezonlin et al., 2006; Félix et al., 2009). It is most likely that genotype-specific base temperatures for development of $B$. fusca occur (Hauptfleisch et al., 2014).

Apart from temperature, photoperiod also has an effect on the development and reproduction of an organism. Factors such as intensity and quality of light directly affect development and reproduction (Philogene \& McNeal, 1984). 


\subsubsection{Busseola fusca moths}

The moths of $B$. fusca are seldom observed in maize fields as they are inactive during the daytime resting on plants or plant debris unless when disturbed (Harris \& Nwanze, 1992). These moths emerge 13 - 14 days after pupation if the conditions are favourable and they usually emerge after sunset or at night (Onyango \& Ochieng'-Odero, 1994; Calatayud et al., 2007). Soon after emergence, the female releases a pheromone and starts calling to attract the males and mating starts soon after (Unnithan, 1987; Calatayud et al., 2007). Hereafter, the female moth searches for a suitable host plant for oviposition. The females normally lay eggs between the youngest unfolded leaf sheaths of the host plant,(Unnithan, 1987; Harris \& Nwanze, 1992). Females find 3 - 4 week old maize plants the most attractive for oviposition (Van Rensburg et al., 1985; Unnithan, 1987). This species prefers to lay eggs on plants with a waxy surface (Haile \& Hofsvang, 2002). Surface texture (smooth surfaces), plant size (stem thickness) and leaf sheath rigidity all play a role in $B$. fusca moths' hostplant suitability for oviposition (Calatayud et al., 2008). The oviposition period takes about 3 - 4 successive nights when conditions are favourable (Harris \& Nwanze, 1992; Calatayud et al., 2007). The steps during the host-finding stage are searching, orientation, encounter, landing, surface evaluation and acceptance (Renwick \& Chew, 1994). A detailed study on oviposition behaviour was done by Calatayud et al. (2008).

The seasonal flight patterns of $B$. fusca peak three times per annum (Van Rensburg et al., 1985; Van Rensburg, 1997; Van Rensburg, 1999). The moths of the third seasonal flight are low in numbers because only a few larvae of the second generation can pupate because the host plants (maize) (late in the production season) are not suitable for oviposition or for feeding of young larvae (Van Rensburg et al., 1985; Krüger, 2006). There are significantly more moths during the second flight than during the first. Maize plants from an early planting date (September to early November) are infested by moths from the first flights resulting in relatively small infestations and those of a late planting date (mid-November) are subject to more severe infestations (Van Rensburg et al., 1985). Busseola fusca population numbers are therefore lower in early planting dates (Abu, 1986). In South Africa, the moth flight season starts from around October and ends around April just before the frost commences (Van Rensburg et al., 1985; Kfir, 1998). Van Rensburg et al. (1985) described the number of $B$. fusca moths as low during the first flight (November), with the second flight that reaches a high peak between January and February and the third flight decreases again to low numbers around March and April. Busseola fusca moth flights were also noted by Jack (1917) who reported the seasonal moth flight to reach a peak during November in 
Potchefstroom, while Du Plessis \& Lea (1943) noted moth flights to start around December in Kroonstad, South Africa. The understanding of seasonal moth flight patterns provide knowledge in seasonal variation and can be used to predict stem borer outbreaks (Van Rensburg, 1997).

\subsubsection{Monitoring of Busseola fusca moths}

Busseola fusca is of economic importance since it causes a decrease in maize production (Kfir, 1998; Kfir et al., 2002). In general, B. fusca is found in maize and sorghum but seldom in wild grasses such as Napier grass (Le Ru et al., 2006a, b). Yield losses by B. fusca can range between 0 - 100\% depending on conditions (Barrow, 1987; Van Rensburg \& Bate, 1987).

Monitoring of moth numbers can provide early-warning of pest outbreaks and also contributes to developing chemical control strategies that rely on accurate timing of pesticide applications. Pheromones are used in integrated pest management programs to monitor population dynamics and to control by mass trapping and mating disruption (Van Rensburg, 1992). Light traps can also be used to determine the seasonal abundance of $B$. fusca populations. Although it is very effective, a three year period or more is needed to determine seasonal moth flight pattern of moths (Van Rensburg et al., 1987). Seasonal rainfall also determines $B$. fusca flight patterns (Van Rensburg et al., 1987) and distinctive patterns occur in areas with only one rainfall season (Van Rensburg, 1997). Planting dates play an important role in avoiding severe infestations by $B$. fusca or any other stem borer pest. Knowing the flight patterns of $B$. fusca can help to determine the optimum planting date to escape high infestation levels.

Accurate knowledge on the effects of temperature on the biology of a South African population of $B$. fusca will assist in modelling climate requirements of this species.

\subsubsection{Objectives}

The objective of this study was to determine the effect of different temperatures on reproduction of $B$. fusca. The longevity, oviposition period, total number of eggs laid, egg fertility and mortality were determined for each temperature regime, evaluated. 


\subsection{Materials and Methods}

\subsubsection{Busseola fusca collection sites}

The collection sites are those described in Chapter 2 (see 2.3.1).

\subsubsection{Fecundity and longevity of female moths}

This study was conducted in a laboratory at the North-West University, Potchefstroom.

After emergence of the moths, single male-female pairs were confined to oviposition chambers (Fig. 2.1a) within 24 hours of emergence. There were 30 oviposition chambers per temperature regime. The temperature regimes used were $15,20,26$, and $30 \pm 1{ }^{\circ} \mathrm{C}, \mathrm{RH}$ of $70 \pm 30 \%$ and a $14 \mathrm{~L}: 10 \mathrm{D}$ photoperiod. The temperature and $\mathrm{RH}$ at each regime was recorded at 30-minute intervals using iButtons ${ }^{\circledR}$ from Coldchain Thermo Dynamics (Fairbridge technologies) as seen in figure 2.2.

The chambers and method used are as described in Chapter 2 (see 2.3.3). The pre- and post-oviposition periods, days without oviposition, longevity and fertility, number of egg batches oviposited and egg production of each adult female were determined. Eggs were counted using a stereo-microscope (Nikon SMZ 1500) and kept in a small plastic container (52 $\mathrm{mm}$ high and $30 \mathrm{~mm}$ in diameter) with a steel mesh infused lid. These containers with eggs were kept in glass desiccators (150 $\mathrm{mm}$ in diameter) in which $\mathrm{RH}$ were maintained at $70 \pm 5 \%$ using a potassium hydroxide solution according to the method of Solomon (1951). The eggs were observed daily until larvae hatched. To determine fertility, the number of eggs that developed to the black head stage was counted and expressed as a percentage of the total number of eggs per female. Eggs that did not develop were regarded as infertile. Larvae that developed to the black head stage were regarded dead, if they had not hatched three weeks after oviposition.

\subsubsection{Statistical analysis}

The effect of temperature on pre-, post-, and oviposition period, longevity of female moths and egg production were analysed by means of one-way ANOVA using STATISTICA 12 (Statsoft, Inc., 2013), followed by Tukey's HSD test $(P=0.05)$. 


\subsection{Results}

Temperature had a significant effect on fecundity and longevity of $B$. fusca moths (Table 3.1). Moths laid eggs at all the temperatures evaluated during this study. There was, however, a significant difference in total number of eggs laid between these temperatures $\left(F_{3,121}=12.02 ; P<0.001\right)$. The total number of eggs laid at 15,20 and $26{ }^{\circ} \mathrm{C}$ was similar, with no significant difference between them. The total number of eggs laid at $30{ }^{\circ} \mathrm{C}$ was approximately a third of those laid at 15,20 and $26^{\circ} \mathrm{C}$ and differed significantly from them (Table 3.1).

Pre-oviposition and oviposition periods were inversely related to temperature (Table 3.1). The pre-oviposition $\left(\mathrm{F}_{3,121}=8.68 ; \mathrm{P}<0.001\right)$ and oviposition $\left(\mathrm{F}_{3,121}=29.06 ; \mathrm{P}<0.001\right)$ periods were significantly longer at $15^{\circ} \mathrm{C}$ than at $30{ }^{\circ} \mathrm{C}$, with no significant difference in the duration of these two reproductive periods between 20 and $26{ }^{\circ} \mathrm{C}$. The post-oviposition period $\left(F_{3,121}=10.72 ; \mathrm{P}<0.001\right)$ was the longest at $15^{\circ} \mathrm{C}$ and similar at 20,26 and $30{ }^{\circ} \mathrm{C}$. Moths died within a day of their last oviposition at 20,26 and $30{ }^{\circ} \mathrm{C}$, but lived between two and three days after oviposition at $15^{\circ} \mathrm{C}$ (Table 3.1). Longevity of female moths differed significantly between the different temperatures $\left(F_{3,121}=59.6, P<0.001\right)$. Longevity of female moths was significantly longer at $15^{\circ} \mathrm{C}$ compared to 20,26 and $30{ }^{\circ} \mathrm{C}$. However, females lived significantly shorter at $30^{\circ} \mathrm{C}$ than at 20 and $26^{\circ} \mathrm{C}$ (Table 3.1).

Moths laid significantly more eggs per day at $26{ }^{\circ} \mathrm{C}$ compared to 15,20 and $30{ }^{\circ} \mathrm{C}\left(\mathrm{F}_{3,121}=\right.$ 10.5; $\mathrm{P}<0.001$ ). The mean number of eggs laid per day at $20^{\circ} \mathrm{C}$ was also significantly higher than at $15^{\circ} \mathrm{C}$ (Table 3.1). The minimum number of eggs laid per female per day was significantly fewer at $15^{\circ} \mathrm{C}$ compared to 26 and $30{ }^{\circ} \mathrm{C}\left(\mathrm{F}_{3.121}=6.6 ; \mathrm{P}<0.001\right)$. The minimum number of eggs laid daily per female moth, was more than 20 eggs at 26 and $30{ }^{\circ} \mathrm{C}$ during their oviposition period (Table 3.1).

The percentage infertile eggs at all temperatures evaluated were high and differed significantly $\left(F_{3,121}=21.79, P<0.001\right)$ although the number of infertile eggs showed no significant difference between the four temperatures evaluated $\left(F_{3,121}=2.0 ; P=0.1\right)$ (Table 3.2). Since there was no fertilisation at $30{ }^{\circ} \mathrm{C}$, fertility was compared at 15,20 and $26{ }^{\circ} \mathrm{C}$ only. There was no significant difference in fertility between the different temperatures (number of fertile eggs and unhatched larvae), although fertility increased from 15 to $26{ }^{\circ} \mathrm{C}$ $\left(F_{2,90}=1.5 ; P=0.2\right)$ (Table 3.2). Differences do, however, exist if it is expressed as percentage fertility $\left(F_{2.90}=3.91 ; \mathrm{P}>0.01\right)$. Fertility was significantly lower at $15^{\circ} \mathrm{C}$ than at 20 
${ }^{\circ} \mathrm{C}$, but it did not differ from percentage fertility at $26^{\circ} \mathrm{C}$. The highest percentage fertility was at $20^{\circ} \mathrm{C}$ and no fertility (as a result of no fertilisation) was recorded at $30{ }^{\circ} \mathrm{C}$. There was also a significant difference in the number $\left(F_{2,90}=9.25 ; P<0.001\right)$ and percentage $\left(F_{2,90}=11.64\right.$; $P<0.001)$ eggs with larvae in the blackhead stage that failed to hatch between the four temperatures evaluated. Since there was no fertilisation at $30^{\circ} \mathrm{C}$, the percentage larvae that were unable to hatch, was compared at 15,20 and $26^{\circ} \mathrm{C}$ only. Percentage hatch was significantly higher at $15^{\circ} \mathrm{C}$ than at 20 and $26^{\circ} \mathrm{C}$. There was therefore a tendency that the failure to hatch was reduced with increasing temperature between 15 and $26{ }^{\circ} \mathrm{C}$, although the percentage unsuccessful hatchings at 20 and $26^{\circ} \mathrm{C}$ did not differ significantly.

\subsection{Discussion}

The reproductive parameters of female $B$. fusca moths were significantly affected by temperature, and oviposition commenced sooner at temperatures higher than $15{ }^{\circ} \mathrm{C}$. The pre- and post-oviposition periods were long, when compared to temperatures between 20 and $30{ }^{\circ} \mathrm{C}$. Energy is therefore used for physiological processes rather than reproductive effort. Although female moths lived longer at $15{ }^{\circ} \mathrm{C}$, the number of days without oviposition was also higher than at the increased temperatures. The mean number of eggs laid per day at $15^{\circ} \mathrm{C}$, was lower than at temperatures between 20 and $26^{\circ} \mathrm{C}$. The total number of eggs laid per female at $15{ }^{\circ} \mathrm{C}$ was not fewer than at 20 and $26{ }^{\circ} \mathrm{C}$, but a high percentage of these eggs were infertile. Most of the larvae that developed to the black head stage at $15^{\circ} \mathrm{C}$ were unable to hatch. Fitness of these larvae was therefore negatively affected by a constant temperature of $15^{\circ} \mathrm{C}$. Hatching success of neonate larvae increased with increasing temperature between 15 and $26{ }^{\circ} \mathrm{C}$. Although not too cold for oviposition, a constant temperature of $15{ }^{\circ} \mathrm{C}$ proved to be too cold for fertility of $B$. fusca. The lower threshold temperature for $B$. fusca reproduction is therefore higher than $15^{\circ} \mathrm{C}$. Goebel (2006) reported a temperature of $15^{\circ} \mathrm{C}$ also to be too low for Chilo sacchariphagus (Lepidoptera: Crambidae) mating and oviposition, with no mating and eggs laid at $15^{\circ} \mathrm{C}$.

The upper limit for $B$. fusca reproduction is below $30^{\circ} \mathrm{C}$ because fewer eggs were laid at 30 ${ }^{\circ} \mathrm{C}$ compared to $26{ }^{\circ} \mathrm{C}, 100 \%$ infertility of eggs occurred and female moths had a short life span at $30^{\circ} \mathrm{C}$. Many infertile eggs $(>100)$ were recorded at all temperature regimes, but the highest egg production and fertility rate of eggs were at 20 and $26^{\circ} \mathrm{C}$. Female longevity was also similar at these two temperatures. These results are in accordance with observations by Fantinou et al. (2004) on Sesamia nonagrioides (Lepidoptera: Noctuidae) where the number of eggs laid and fertility increased from $15^{\circ} \mathrm{C}$ to $27.5^{\circ} \mathrm{C}$ but declined significantly at $30{ }^{\circ} \mathrm{C}$. 
However, Chilo sacchariphagus (Lepidoptera: Crambidae) had a higher upper fertility temperature where the mean number of eggs laid increased from $17{ }^{\circ} \mathrm{C}$ to $30{ }^{\circ} \mathrm{C}$ but reached a low number only at $35{ }^{\circ} \mathrm{C}$ (Goebel, 2006). Fecundity usually increases as temperature increases, between a lower and upper threshold, up to the optimum point (Milonas \& Savopoulou-Soultani, 2000). The lower threshold for both these stem borer species is therefore above $15^{\circ} \mathrm{C}$ and the upper threshold is in the mid-twenties for $B$. fusca. The best suited temperature for adult fecundity of the stem borer Chilo partellus (Lepidoptera: Crambidae), is between $26-30^{\circ} \mathrm{C}$ (Tamiru et al., 2012).

During this study, the females of $B$. fusca laid about 300 - 400 eggs at temperatures between 15 and $26{ }^{\circ} \mathrm{C}$. This was more than the average of $243-299$ eggs between 18 and $25^{\circ} \mathrm{C}$ reported by Khadioli et al. (2014), but in accordance with Harris (1962) who reported an average of 400 eggs per female and Kruger et al. (2012) who reported summer moths to lay an average of 374 eggs. However, Unnithan (1987) reported a high average fecundity number of 855 when reared in the laboratory. In this study, the highest number of eggs laid by a single moth was 976 . Although $B$. fusca moths can lay many eggs and the potential offspring may be many, the realised offspring may be few. Depending on the temperature that prevails, not all eggs will be fertilised resulting in reduced fertility and thus low larval numbers. The more eggs are laid, the higher the probability that some of the offspring survives and reproduce (Speight et al., 2008). The total number of eggs laid at $30{ }^{\circ} \mathrm{C}$, decreased by more than half the number of eggs laid at the other temperatures. This significant reduction indicates that $30{ }^{\circ} \mathrm{C}$ is not suitable for oviposition by $B$. fusca moths. Although the quantity of eggs is important, high quality of eggs will provide strong offspring. The quality of the eggs is determined by energy and resources available from the adults collected during their larval stage (Riddick, 2006; Speight et al., 2008).

Longevity of female moths decreased as the temperature increased (14.9 - 5.2 days) at a 14L: 10D photoperiod. Khadioli et al. (2014) reported similar results for female moth longevity ranging from $12.4-4.7$ days from $15-30{ }^{\circ} \mathrm{C}$ and at $12 \mathrm{~L}: 12 \mathrm{D}$ photoperiod. Unnithan (1987) reported an average longevity of 7.47 days for female moths of $B$. fusca reared in a laboratory. Similar results were recorded for $S$. nonagrioides moths at different temperatures $\left(15-30^{\circ} \mathrm{C}\right)$ and $16 \mathrm{~L}: 8 \mathrm{D}$ photoperiod with longevity declining from 7.6 to 3.9 days as the temperature increased (Fantinou et al., 2004). For C. partellus, longevity was also negatively affected by increasing temperature from $22-30{ }^{\circ} \mathrm{C}$ (Tamiru, 2012), and for S. calamistis it ranged from $6.7-9.9$ days between $15-30{ }^{\circ} \mathrm{C}$ at $12 \mathrm{D}: 12 \mathrm{~L}$ photoperiod (Khadioli et al., 2014). 
Studies of pest development at a range of constant temperatures can give valuable insight on the population dynamics of a species and help with pest management strategies (McFarland et al., 1992; Shanower et al., 1993). These conditions differ from environmental conditions in natural habitats where the temperatures fluctuate and the host plants are less abundant. Fecundity under natural conditions will therefore be determined by the amount of time that females spend on mating and host finding behavior. Oviposition behaviour involves sexual behaviour, calling and mating during the scotophase, and oviposition which occurs in the dark over a period of several days (Calatayud et al., 2007). Successful oviposition behaviour ensures better survival for the offspring. Night temperatures in South Africa are usually not high and will not be a limiting factor for oviposition. The lifespan of female moths may, however, be inhibited by high temperatures exceeding $30{ }^{\circ} \mathrm{C}$ that may prevail during daytime.

Busseola fusca have three distinctive flight patterns per annum in South Africa, of which the second is the most severe (Van Rensburg et al., 1985). There exists a temperature and rainfall gradient from east to west in the maize production area of South Africa (Van Rensburg et al., 1985). The number of $B$. fusca moths increases significantly over this gradient from east to west especially during the third flight season (Van Rensburg et al,. 1985). First moth flights commences earlier in the east than the west causing larvae to enter diapause earlier in the eastern areas than in the west (Walters, 1979), thus leading to no third moth flight in the east but increasing moth flights to the west (Van Rensburg et al., 1985). The pattern in south-western Nigeria is the opposite since spring rains start earlier in the east than in the west (Usua, 1968). This leads to earlier planting dates in the east and also earlier dates for diapause initiation in $B$. fusca.

Knowledge on thermal limits for $B$. fusca reproduction and understanding their response to changes in temperature can contribute to modelling of climate requirements of $B$. fusca in different regions and assist in predicting pest outbreaks. Changes in climate may cause extinction of species or severe outbreaks, depending how they react to these changes. Although insects can adapt to environmental changes, extreme conditions may be too harsh to survive.

Development studies such as those described in this study provide information on the optimal and lethal temperatures for specific species. The effect of fluctuating temperatures on $B$. fusca reproduction and development is, however, not known. A study on Adoxophyes orana (Lepidoptera: Tortricidae) reported that fluctuating temperatures causes a shorter life 
span than constant temperatures (Mironidis \& Savopoulou-Soultani, 2008), and should therefore be investigated for $B$. fusca too.

\subsection{References}

Abu, J. F. 1986. Biology and control of the insect pests of sorghum in the Southern Guinea savanna zone of Nigeria. Institute for Agricultural Research Samaru, Zaria, Nigeria. 23 p.

Ali, A. \& Rizvi, P.Q. 2008. Effect of varying temperature on the survival and fecundity of Coccinella septempunctata (Coleoptera: Coccinellidae) fed on Lipaphis erysimi (Hemiptera: Aphididae). Journal of Entomology 5: 133-137.

Barrow, M.R. 1987. The effect of first generation maize stalkborer, Busseola fusca (Fuller) (Lepidoptera: Noctuidae), on yield of different maize genotypes. Journal of the Entomological Society of Southern Africa 50: 291-298.

Calatayud, P.A., Guénégo, H., Le Ru, B., Silvain, J.F. \& Frérot, B. 2007. Temporal patterns of emergence, calling behaviour and oviposition period of the maize stem borer, Busseola fusca (Fuller) (Lepidoptera: Noctuidae). Annales de la Societe Entomologique de France 43: 63-68.

Calatayud, P.A., Guénégo, H., Ahuya, P., Wanjoya, A., Le Ru, B., Silvain, J.F. \& Frérot, B. 2008. Flight and oviposition behaviour of the African stem borer, Busseola fusca, on various host plant species. Entomologia Experimentalis et Applicata 129: 348-355.

Du Plessis, C. \& Lea, H.A.P. 1943. The maize stalk borer, Calamistis fusca (Hmps). Bulletin of the Department of Agriculture and Forestry, Union of South Africa, 238: 1-51.

Fantinou, A.A., Perdikis, D.Ch. \& Zota, K.F. 2004. Reproductive responses to photoperiod and temperature by diapausing and nondiapausing populations of Sesamia nonagrioides Lef. (Lepidoptera - Noctuidae). Physiological Entomology 29: 169-175.

Félix, A.E., Genestier, G., Malosse, C., Calatayud, P.A., Le Ru, B., Silvain, J.F. \& Frérot, B. 2009. Variability in pheromone communication among different haplotype populations of Busseola fusca. Journal of Chemical Ecology 35: 618-623. 
Goebel, R. 2006. The effect of temperature on development and reproduction of the sugarcane stalk borer, Chilo sacchariphagus (Bojer 1856) (Lepidoptera: Crambidae). African Entomology 14: 103-111.

Haile, A. \& Hofsvang, T. 2002. Host plant preference of the stem borer Busseola fusca (Fuller) (Lepidoptera: Noctuidae). Crop Protection 21: 227-233.

Hallman, G.J. \& Denlinger, D.L. 1998. Introduction: temperature sensitivity and integrated pest management, p.1-5. (In Hallman, G.J. \& Denlinger, D.L., eds. Temperature sensitivity in insects and application in integrated pest management. Boulder: Westview Press. 311p).

Harris, K.M. 1962. Lepidopterous stem borers of cereals in Nigeria. Bulletin of Entomology Research 53: 139-171.

Harris, K.M. \& Nwanze, K.F. 1992. Busseola fusca (Fuller), the African maize stem borer: a handbook of information. Information Bulletin no. 33. Patancheru, A.P. 502 324, India: International Crops Research Institute for the Semi-Arid Tropics, and Wallingford, UK: CAB International. $84 \mathrm{p}$.

Hauptfleisch, K., Yonow, T., Kriticos, D.J. \& Ota, N. 2014. Busseola fusca. HarvestChoice Pest Geography. St. Paul, MN: InSTePP-HarvestChoice. 6 p.

He, X., Wang, Q. \& Carpenter, A. 2003. Thermal requirements for the development and reproduction of Nysius huttoni White (Heteroptera: Lygaeidae). Journal of Economic Entomology 96: 1119-1125.

Jack, R.W. 1917. The maize stalk borer: General account of life history and control measures. Department of Agriculture of Rhodesia, Bulletin, 276.

Kfir, R. 1998. Maize and grain sorghum: southern Africa. (In Polaszek, A., ed. African cereal stem borers: economic importance, taxonomy, natural enemies and control. CAB International, Wallingford. p. 29-37).

Kfir, R., Overholt, W.A., Khan, Z.R. \& Polaszek, A. 2002. Biology and management of economically important lepidopteran cereal stem borers in Africa. Annual Review of Entomology 47: 701-731. 
Khadioli, N., Tonnang, Z.E.H., Ong'amo, G., Achia, T., Kipchirchir, I., Kroschel, J. \& Le Ru, B. 2014. Effect of temperature on the life history parameters of noctuid lepidopteran stem borers, Busseola fusca and Sesamia calamistis. Annals of Applied Biology 165: 373-386.

Kim, D.S. \& Lee, J.H. 2003. Oviposition model of Carposina sasakii (Lepidoptera: Carposinidae). Ecological Modelling 162: 145-153.

Krüger, W. 2006. Ecology of maize stemborers in irrigated subsistence farming systems in the Limpopo province. Unpublished M.Sc. thesis. North-West University, Potchefstroom, South Africa.

Kruger, M., Van Rensburg, J.B.J. \& Van den Berg, J. 2012. Reproductive biology of Btresistant and susceptible field-collected larvae of the maize stem borer, Busseola fusca (Lepidoptera: Noctuidae). African Entomology 20: 35-43.

Le Ru, B.P., Ong'amo, G.O., Moyal, P., Muchungu, E., Ngala, L., Musyoka, B., Abdullah, Z., Matama-Kauma, T., Lada, V.Y., Pallangyo, K., Sidumo, A., Omwega, C., Schulthess, F., Calatayud, P.A. \& Silvain, J.F. 2006a. Major ecological characteristics of East African noctuid stem borers. Annales de la Societe Entomologique de France 42: 353-361.

Le Ru, B.P., Ong'amo, G.O., Moyal, P., Ngala, L., Musyoka, B., Abdullah, Z., Cugala, D., Defabachew, B., Haile, T.A., Kauma Matama, T., Lada, V.Y., Negassi, B., Pallangyo, K., Ravolonandrianina, J., Sidumo, A., Omwega, C.O., Schulthess, F., Calatayud, P.A. \& Silvain, J.F. 2006b. Diversity of lepidopteran stem borers on monocotyledonous plants in eastern Africa and the islands of Madagascar and Zanzibar revisited. Bulletin of Entomology Research 96: 1-9.

McFarland, M., McCann, I.R. \& Kline, K.S. 1992. Synthesis and measurement of temperature for insect models. (In Goodenough, J.L \& McKinion, J.M., eds. Basics of insect modeling. American Society of Agricultural Engineers, St Joseph, MI, U.S.A. p. 7592).

Milonas, P.G. \& Savopoulou-Soultani, M. 2000. Development, survivorship, and reproduction of Adoxophyes orana (Lepidoptera: Tortricidae) at constant temperatures. Annals of the Entomological Society of America 93: 96-102. 
Mironidis, G.K. \& Savopoulou-Soultani, M. 2008. Development, survivorship, and reproduction of Helicoverpa armigera (Lepidoptera: Noctuidae) under constant and alternating temperatures. Environmental Entomology 37: 16-28.

Onyango, F.O. \& Ochieng'-Odero, J.P.R. 1994. Continuous rearing of the maize stem borer Busseola fusca on an artificial diet. Entomologia Experimentalis et Applicata 73: 139-144.

Philogene, B.J.R. \& McNeal, J.N. 1984. The influence on the nondiapause related aspects of development and reproduction in insects. Photochemistry and Photobiology 40: 753-761.

Renwick, J.A.A. \& Chew, F.S. 1994. Oviposition behavior in Lepidoptera. Annual Review of Entomology 39: 377-400.

Riddick, E.W. 2006. Egg load and body size of lab-cultured Cotesia marginiventris. BioControl 51: 603-610.

Sezonlin, M., Dupas, S., Le Ru, B., Le Gall, P., Moyal, P., Calatayud, P.A., Giffard, I., Faure, N., \& Silvain, J.F. 2006. Phylogeography and population genetics of the maize stalk borer Busseola fusca (Lepidoptera, Noctuidae) in sub-Saharan Africa. Molecular Ecology 15: 407420.

Shanower, T.G., Schultess, F. \& Bosque-Perez, N. 1993. Development and fecundity of Sesamia calamistis (Lepidoptera: Noctuidae) and Eldana saccharina (Lepidoptera: Pyralidae). Bulletin of Entomological Research 83: 237-243.

Solomon, M.E. 1951. Control of humidity with potassium hydroxide, sulphuric acid or other solutions. Bulletin of Entomological Research 42: 543-554.

Son, Y. \& Lewis, E.E. 2005. Effects of temperature on the reproductive life history of the black wine weevil, Otiorhynchus sulcatus. Entomologia Experimentalis et Applicata 114: 1524.

Speight, M.R., Hunter, M.D. \& Watt, A.D. 2008. Ecology of insects: concepts and applications. $2^{\text {nd }}$ ed. John Wiley \& Sons Ltd, UK. 640 p. 
Sporleder, M., Kroschel, J., Quispe, M.R.G. \& Lagnaoui, A. 2004. A temperature-based simulation model for the potato tuberworm, Phthorimaea operculella Zeller (Lepidoptera: Gelechiidae). Environmental Entomology 33: 477-486.

StatSoft, Inc. 2013. STATISTICA (data analysis software system), version 12. www.statsoft.com.

Tamiru, A., Getu, E., Jembere, B. \& Bruce, T. 2012. Effect of temperature and relative humidity on the development and fecundity of Chilo partellus (Swinhoe) (Lepidoptera: Crambidae). Bulletin of Entomological Research 102: 9-15.

Unnithan, G.C. 1987. Development and reproductive biology of the maize stem borer Busseola fusca Fuller (Lepidoptera: Noctuidae). Journal of Applied Entomology 104: 172179.

Usua, E.J. 1968. The biology and ecology of Busseola fusca and Sesamia species in south-western Nigeria. I. Distribution and population studies. Journal of Economic Entomology 61: 830-833.

Van Rensburg, G.D.J \& Bate, R. 1987. Preliminary studies on the relative abundance and distribution of the stalk borers Busseola fusca and Chilo partellus. Technical Communication, Department of Agriculture and Water Supply, Republic of South Africa, 212: 49-52.

Van Rensburg, J.B.J. 1992. Evaluation of pheromone trapping systems in relation to light trap captures of the maize stalk borer, Busseola fusca (Fuller) (Lepidoptera: Noctuidae). South African Journal of Plant and Soil 9: 144-149.

Van Rensburg, J.B.J. 1997. Seasonal moth flight activity of the maize stalk borer, Busseola fusca (Fuller) (Lepidoptera: Noctuidae) in small farming areas of South Africa. Applied Plant Science 11: 20-23.

Van Rensburg, J.B.J. 1999. The maize stalk borer in South Africa. Crop protection series no. 14, ARC-Grain Crops Institute, Potchefstroom. 
Van Rensburg, J.B.J, Walters, M.C. \& Giliomee, J.H. 1985. Geographical variation in the seasonal moth flight activity of the maize stalk borer, Busseola fusca (Fuller), in South Africa. South African Journal of Plant and Soil 2: 123-126.

Van Rensburg, J.B.J., Walters, M.C. \& Giliomee, J.H. 1987. The influence of rainfall on seasonal abundance and flight activity of the maize stalk borer, Busseola fusca in South Africa. South African Journal of Plant and Soil 4: 183-187.

Walters, M.C. 1979. Die invloed van weer op mielieplae. (In Die waarde van fenologie by die verhoging van doeltreffendheid van akkerbougewasse. Departement van Landboutegniese Dienste. Tegniese Mededeling 150: 64-7 
Table 3.1: Mean fecundity and longevity ( \pm S.E.) of Busseola fusca moths at constant temperatures.

\begin{tabular}{|c|c|c|c|c|c|c|c|c|c|c|c|}
\hline $\begin{array}{l}\text { Temperature } \\
\left( \pm 1^{\circ} \mathrm{C}\right)\end{array}$ & $\mathbf{n}$ & $\begin{array}{l}\text { Total no. of } \\
\text { eggs laid }\end{array}$ & $\begin{array}{l}\text { Pre- } \\
\text { oviposition } \\
\text { (days) }\end{array}$ & $\begin{array}{l}\text { Oviposition } \\
\text { (days) }\end{array}$ & $\begin{array}{l}\text { Post- } \\
\text { oviposition } \\
\text { (days) }\end{array}$ & $\begin{array}{l}\text { Longevity } \\
\text { of adult } \\
\text { female } \\
\text { (days) }\end{array}$ & $\begin{array}{l}\text { No. of } \\
\text { days } \\
\text { during } \\
\text { which no } \\
\text { eggs } \\
\text { were laid }\end{array}$ & $\begin{array}{l}\text { Mean no. of } \\
\text { eggs laid } \\
\text { per day }\end{array}$ & $\begin{array}{l}\text { Max no. of } \\
\text { eggs laid per } \\
\text { day }\end{array}$ & $\begin{array}{l}\text { Min no. of } \\
\text { eggs laid } \\
\text { per day }\end{array}$ & $\begin{array}{l}\text { Mean } \\
\text { number of } \\
\text { egg batches } \\
\text { per female }\end{array}$ \\
\hline 15 & 30 & $336.7 \pm 37.3 \mathrm{a}$ & $\begin{array}{l}3.3 \pm 0.3 c \\
(1-9)\end{array}$ & $\begin{array}{l}8.9 \pm 0.7 c \\
(1-16)\end{array}$ & $\begin{array}{l}2.7 \pm 0.5 b \\
(0-15)\end{array}$ & $14.9 \pm 0.8 c$ & $1.5 \pm 0.3 b$ & $39.0 \pm 4.5 \mathrm{a}$ & $119.2 \pm 14.3 a b$ & $4 \pm 1.5 \mathrm{a}$ & $6.73 \pm 0.79 a b$ \\
\hline 20 & 36 & $345.0 \pm 28.1 \mathrm{a}$ & $\begin{array}{l}2.5 \pm 0.2 a b \\
(1-6)\end{array}$ & $\begin{array}{l}5.2 \pm 0.4 b \\
(1-10)\end{array}$ & $\begin{array}{l}0.8 \pm 0.2 \mathrm{a} \\
(0-3)\end{array}$ & $8.5 \pm 0.4 \mathrm{a}$ & $0.5 \pm 0.1 \mathrm{a}$ & $68.5 \pm 5.2 b$ & $182.4 \pm 15.7 b c$ & $11.1 \pm 2.9 \mathrm{ab}$ & $7.97 \pm 0.69 b$ \\
\hline 26 & 27 & $396.1 \pm 57.9 a$ & $\begin{array}{l}2.7 \pm 0.3 b c \\
(1-7)\end{array}$ & $\begin{array}{l}4.5 \pm 0.9 a b \\
(2-11)\end{array}$ & $\begin{array}{l}0.9 \pm 0.2 \mathrm{a} \\
(0-4)\end{array}$ & $8.2 \pm 0.4 \mathrm{a}$ & $0.3 \pm 0.1 \mathrm{a}$ & $100.0 \pm 16.3 c$ & $206.2 \pm 33.9 c$ & $27.0 \pm 7.3 c$ & $7 \pm 0.6 a b$ \\
\hline 30 & 32 & $118.7 \pm 13.9 b$ & $\begin{array}{l}1.7 \pm 0.1 \mathrm{a} \\
(1-3)\end{array}$ & $\begin{array}{l}2.9 \pm 0.2 \mathrm{a} \\
(1-6)\end{array}$ & $\begin{array}{l}0.6 \pm 0.2 \mathrm{a} \\
(0-4)\end{array}$ & $5.2 \pm 0.3 b$ & $0.2 \pm 0.1 \mathrm{a}$ & $43.9 \pm 4.3 a b$ & $70.6 \pm 7.4 \mathrm{a}$ & $22.6 \pm 3.4 \mathrm{bc}$ & $5.22 \pm 0.58 a$ \\
\hline
\end{tabular}

Values in brackets represent the range in days.

Means in each column followed by the same letter are not significantly different (Tukey's HSD, P = 0.05). 
Table 3.2: Fertility ( \pm S.E.) of Busseola fusca eggs at constant temperatures.

\begin{tabular}{|c|c|c|c|c|c|c|c|c|}
\hline $\begin{array}{l}\text { Temperature } \\
\left( \pm 1^{\circ} \mathrm{C}\right)\end{array}$ & $\mathbf{n}$ & $\begin{array}{l}\text { Total no. of } \\
\text { eggs laid }\end{array}$ & Infertile eggs & $\begin{array}{l}\% \text { Infertile } \\
\text { eggs }\end{array}$ & \#Fertility & \% Fertility & $\begin{array}{l}\text { Unhatched } \\
\text { larvae }\end{array}$ & $\begin{array}{l}\% \text { Unhatched } \\
\text { larvae }\end{array}$ \\
\hline 15 & 30 & $336.7 \pm 37.3 a$ & $161.2 \pm 20.7 \mathrm{a}$ & $63.7 \mathrm{~b}$ & $175.5 \pm 36.5 a$ & $36.3 \pm 6.6 \mathrm{a}$ & $127.5 \pm 29.4 \mathrm{a}$ & $26.3 \pm 5.5 a$ \\
\hline 20 & 36 & $345.0 \pm 28.1 \mathrm{a}$ & $103.4 \pm 17.3 \mathrm{a}$ & $37.3 \mathrm{a}$ & $241.6 \pm 27.7 \mathrm{a}$ & $62.8 \pm 5.8 b$ & $71.8 \pm 12.3 a b$ & $18.1 \pm 2.5 \mathrm{a}$ \\
\hline 26 & 27 & $396.1 \pm 57.9 \mathrm{a}$ & $110.5 \pm 21.1 \mathrm{a}$ & $51.0 \mathrm{ab}$ & $285.6 \pm 65.6 \mathrm{a}$ & $49.1 \pm 8.6 \mathrm{ab}$ & $10.3 \pm 3.4 b$ & $1.8 \pm 0.5 b$ \\
\hline 30 & 32 & $118.7 \pm 13.9 b$ & $118.7 \pm 13.9 a$ & $100 \mathrm{c}$ & - & - & - & - \\
\hline
\end{tabular}

Means in each column followed by the same letter are not significantly different (Tukey's HSD, $P=0.05$ ).

\#Fertility = number of fertile eggs 


\section{CHAPTER 4}

\section{Conclusion}

Busseola fusca is the most important insect pest of maize in South Africa. It is also one of the major stem borer species found in other African countries. The density of stem borers was reported to be much lower in wild host plants than in cultivated crops (Gounou \& Schulthess, 2004). These results were confirmed for B. fusca by Moolman et al. (2014). This emphasises the importance of maize as the primary host plant of this species in South Africa. Survival on maize is therefore essential for the existence of $B$. fusca. There are three peaks in the B. fusca moth flight pattern in South Africa (Van Rensburg et al., 1985; Van Rensburg, 1997). The moth flight season is from October until April each year (Van Rensburg et al., 1985; Kfir, 1998), which coincides with the maize production season in South Africa.

Temperature is considered as one of the most important abiotic factors affecting various life history parameters of insects (Hallman \& Denlinger, 1998; He et al., 2003). This study provides information about the effect of temperature on the development and reproduction of B. fusca. This study was conducted at five constant temperatures, viz. 15, 18, 20, 26 and 30 $\pm 1{ }^{\circ} \mathrm{C}$ and a 14L: 10D photoperiod. Temperature affected both development and reproduction of $B$. fusca significantly. Development rate of larvae was inversely related to temperature from 15 to $26{ }^{\circ} \mathrm{C}$. The most favourable temperature range for development was between 26 and $30{ }^{\circ} \mathrm{C}$. Most of the development time of $B$. fusca larvae ( $80 \%$ and more) is spent in instar six onwards and the maize crop is therefore exposed to the more damaging stage of this pest species for long periods which contributes to its pest status in terms of damage to maize plants. Development time of the egg stage varied between 22.5 and 6.5 days at 15 and $26^{\circ} \mathrm{C}$; the larval stage between 90.2 and 32.1 days; the pupal stage between 40.0 and 14.0 days, and the duration of egg-to-adult was 152.6 and 52.6 days, at the two respective temperatures. The lower development threshold temperatures were calculated for eggs $\left(10.36{ }^{\circ} \mathrm{C}\right)$, larvae $\left(8.99^{\circ} \mathrm{C}\right)$, pupae $\left(8.14^{\circ} \mathrm{C}\right)$ and the total life cycle (egg-to-adult) $(8.84$ $\left.{ }^{\circ} \mathrm{C}\right)$. The lower development threshold for larvae and pupae was higher than for eggs, indicating the eggs to be the more sensitive stage in the life cycle. The degree-days needed to complete development were calculated using the abovementioned lower threshold temperatures. For total development from egg-to-adult at constant temperatures of 15 and $26{ }^{\circ} \mathrm{C}, 1348.98$ and 465.03 degree-days are needed, respectively. The very slow development rate at $15^{\circ} \mathrm{C}$ and almost no survival indicated that a constant temperature of 
$15^{\circ} \mathrm{C}$ is too low for $B$. fusca development. Most of the eggs laid by $B$. fusca moths a constant temperature of $15^{\circ} \mathrm{C}$ were also infertile or larvae that developed to the black head stage failed to hatch. A constant temperature of $15^{\circ} \mathrm{C}$ is therefore too cold for fertility of $B$. fusca. The percentage infertile eggs laid at a constant temperature of $30^{\circ} \mathrm{C}$, was $100 \%$ and females had a short life span. A constant temperature of $30^{\circ} \mathrm{C}$ is therefore too warm for $B$. fusca reproduction. The optimum temperature range for $B$. fusca oviposition and fertility was determined to be between $20-26^{\circ} \mathrm{C}$.

Climate change results in changes in global temperatures which in turn result in weather extremes. It is predicted that climate change will cause a rise in global temperature of between $1.4-5.8^{\circ} \mathrm{C}$ by 2100 (IPCC, 2007). The development, survival and abundance of insects will, as a result, be affected. Climate change will not only affect insects directly by impacting on their physiology and behaviour, but also indirectly, through changes that may be affected in their host plants (Bale et al., 2002).

For insects, synchronised growth and development between host plant and specific insect stages is important, especially in temperate regions where the host plant as food resource is only available for a limited period of time within the growing season. As climate becomes less favourable, synchronisation becomes more critical and fewer insects are successful at completing their life cycle (Bale et al., 2002). The impact that climate change will have on $B$. fusca in South Africa is unknown. However, the effect of increasing temperature on maize production will also have an impact on the pest. The strategy used by $B$. fusca for survival during cold temperatures is to enter into diapause during the cold winter period (Kfir, 1991; Kfir et al., 2002). During diapause, no activity occurs and this leads to a profound drop in metabolic rate which is linked to an increase in cold hardiness of larvae (Bale et al., 2002). It can therefore be speculated that if winter temperatures rise as a result of climate change, commencement of the first moth flight of $B$. fusca may be earlier in the year and mayresult in most moths not finding suitable host plants to oviposit on. However, higher soil temperatures may also result in earlier planting by farmers, especially under irrigation, which then may coincide with the earlier moth flights. This in turn may result in an additional generation and a higher peak in the third moth flight resulting in more damage to maize crops planted later.

Head capsule widths are frequently used to determine the number of instars for insects. It was also used in this study and head capsule widths for $B$. fusca ranged from $0.32-2.64$ $\mathrm{mm}$ up to instar eight. Head capsule widths for instar one to four did not overlap, but overlapping occurred from instar 5 onwards. There was no difference in head capsule width of instars seven and eight. Dyar's rule proved to be applicable for instar one to seven, but 
not for instar eight. This information can be used in the field to identify instars and determine the age of a population during the growing season (Calvo \& Molina, 2008). More than eight instars were also found for $B$. fusca under less favourable conditions during this study. Head capsule widths of these extra instars did, however, not differ from the previous instars.

Determining the effect of fluctuating temperatures on the development of $B$. fusca may improve on the accuracy of the parameters determined in this constant temperature study. Data from this study do, however, have significant prediction and modelling value.

\subsection{References}

Bale, J.S., Masters, G.J., Hodkinson, I.D., Awmack, C., Bezemer, T.M., Brown, V.K., Butterfield, J., Buse, A., Coulson, J.C., Farrar, J., Good, J.E.G., Harrington, R., Hartley, S., Jones, T.H., Lindroth, R.L., Press, M.C., Symrnioudis, I., Watt, A.D. \& Whittaker, J.B. 2002. Herbivory in global climate change research: direct effects of rising temperature on insect herbivores. Global Change Biology 8: 1-16.

Calvo, D. \& Molina, J.M. 2005. Developmental rates of the lappet moth Streblote panda Hübner [1820] (Lepidoptera: Lasiocampidae) at constant temperatures. Spanish Journal of Agricultural Research 3: 319-325.

Gounou, S. \& Schulthess, F. 2004. Spatial distribution of lepidopterous stem borers on indigenous host plants in West Africa and its implications for sampling schemes. African Entomology 12: 171-178.

Hallman, G.J. \& Denlinger, D.L. 1998. Introduction: temperature sensitivity and integrated pest management. (In Hallman, G.J. \& Denlinger, D.L., eds. Temperature sensitivity in insects and application in integrated pest management. Boulder: Westview Press. p. 1-6).

He, X., Wang, Q. \& Carpenter, A. 2003. Thermal requirements for the development and reproduction of Nysius huttoni White (Heteroptera: Lygaeidae). Journal of Economic Entomology 96: 1119-1125.

IPCC. 2007. Climate Change 2007: Synthesis Report. Contribution of Working Groups I, II and III to the Fourth Assessment. Report of the Intergovernmental Panel on Climate Change. Geneva, Switzerland. 104 p. 
Kfir, R. 1991. Duration of diapause in the stem borers, Busseola fusca and Chilo partellus. Entomologia Experimentalis et Applicata 61: 265-270.

Kfir, R. 1998. Maize and grain sorghum: southern Africa. (In Polaszek, A., ed. African cereal stem borers: economic importance, taxonomy, natural enemies and control. CAB International, Wallingford. p. 29-37).

Kfir, R., Overholt, W.A., Khan, Z.R. \& Polaszek, A. 2002. Biology and management of economically important Lepidopteran cereal stem borers in Africa. Annual Review of Entomology 47: 701-731.

Moolman, H.J., Van den Berg, J., Conlong, D., Cugala, D., Siebert, S.J. \& Le Ru, B.P. 2014. Species diversity and distribution of lepidopteran stem borers in South Africa and Mozambique. Journal of Applied Entomology 138: 152-166.

Van Rensburg, J.B.J. 1997. Seasonal moth flight activity of the maize stalk borer, Busseola fusca (Fuller) (Lepidoptera: Noctuidae) in small farming areas of South Africa. Applied Plant Science 11: 20-23.

Van Rensburg, J.B.J, Walters, M.C. \& Giliomee, J.H. 1985. Geographical variation in the seasonal moth flight activity of the maize stalk borer, Busseola fusca (Fuller), in South Africa. South African Journal of Plant and Soil 2: 123-126. 